\title{
A Selective Butyrate Esterase Probe for the Rapid Colorimetric and Fluorogenic Identification of Moraxella catarrhalis
}

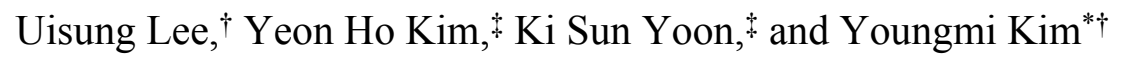 \\ tDepartment of Chemistry and Research Institute of Basic Sciences, Kyung Hee University, 26 Kyungheedae- \\ ro, Dongdaemun-gu, Seoul, 02447, Korea. \\ Department of Food and Nutrition, Kyung Hee University, 26 Kyungheedae-ro, Dongdaemun-gu, Seoul, \\ 02447 , Korea.
youngmi.kim@khu.ac.kr
Tel: +82 2-961-9537
Fax: +82 2-961-0443

\section{Table of Contents:}

1. Synthesis of Compounds $\quad$ S3

2. Photophysical Properties of Compounds $\quad$ S6

3. Stability Studies of B-MC4 and 4-MUB-in Aqueous Solution $\quad$ S12

$\begin{array}{ll}\text { 4. Sensory Responses of Probes toward Esterase Activity } & \text { S21 }\end{array}$

5. Kinetic Studies of the Reaction of Probes (B-MC4 and 4-MUB) with Esterase 532

6. Inhibition Assay $\quad \mathbf{S 3 6}$

7. DLS analysis of B-MC4 before and after incubation with PLE $\quad$ S39

8. Application for the Detection of Moraxella catarrhalis $\quad \mathbf{S 4 0}$

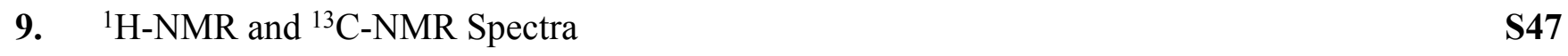

$\begin{array}{lll}10 & \text { References } & \text { S51 }\end{array}$ 


\section{Experimental}

\section{Materials}

All reagents and solvents were of reagent grade quality, purchased commercially, and used as received without further purification unless otherwise noted. Anhydrous $\mathrm{CH}_{2} \mathrm{Cl}_{2}$, anhydrous tetrahydrofuran (THF), dimethyl sulfoxide (DMSO), $N, N$-dimethylformamide (DMF), 4-hydroxybenzyl alcohol, reduced glutathione (GSH), and 4-(2-aminoethyl)benzenesulfonyl fluoride hydrochloride (AEBSF), and sodium fluoride (NaF) were purchased from Alfa Aesar. Flash column chromatography was performed using silica gel $(40 \mu \mathrm{m})$, which was supplied from Qingdao Meigao Chem. Co., Ltd (Chengyang, China). Butyryl chloride, 4-methylumbelliferone (4-MU), porcine liver esterase (PLE, EC 3.1.1.1, $17 \mathrm{U} / \mathrm{mg}$ ), lipase from porcine pancreas (PPL, EC 3.1.1.3, 100-500 U/mg), trypsin from porcine pancreas (EC 3.4.21.4, 1000-2000 U/mg), lysozyme human (EC 3.2.1.17, 100,000 U/mL), alkaline phosphatase from porcine kidney (EC 3.1.3.1 $100 \mathrm{U} / \mathrm{mg}$ ), bovine serum albumin (BSA), sodium hydrosulfide, L-tryptophan, L-cysteine, L-serine, L-lysine, L-histidine, L-arginine, homocysteine, glucose, photassium dioxide, and dithiothreitol (DTT) were purchased from Aldrich (Saint Louis, MO). Hydrogen peroxide $\left(\mathrm{H}_{2} \mathrm{O}_{2}\right)$, sodium hypochlorite $(\mathrm{NaOCl})$, sodium phosphate dibasic, sodium chloride, potassium chloride, potassium phosphate monobasic, and potassium carbonate were obtained by Samchun Co. (Korea). Aqueous solutions were freshly prepared with deionized water from a water purification system (Younglin. Korea). Compounds $\mathbf{1},{ }^{1} \mathbf{2},{ }^{1} \mathbf{3},{ }^{2}$ and $\mathbf{4}-\mathbf{M U B}^{3}$ were prepared as described in literature.

\section{General methods, instrumentation and measurements}

Synthetic manipulations that required an inert atmosphere (where noted) were carried out under a nitrogen using standard Schlenk techniques. NMR $\left({ }^{1} \mathrm{H}\right.$ and $\left.{ }^{13} \mathrm{C}\right)$ spectra were recorded on Bruker Avance $400 \mathrm{MHz}$ spectrometer or JEOL $500 \mathrm{MHz}$ spectrometer. The ${ }^{1} \mathrm{H}$ and ${ }^{13} \mathrm{C}$ chemical shifts $(\delta)$ were reported in units of parts per million ( $\mathrm{ppm}$ ), referenced to the residual solvent. Splitting patterns are denoted as s (singlet), d (doublet), $\mathrm{t}$ (triplet), q (quartet), $\mathrm{m}$ (multiplet), and br (broad). High-resolution electrospray ionization (ESI) mass spectra were obtained at the Korean National Center for Inter-University Research. UV-Vis absorption spectra were obtained on a Scinco UV S-3100 spectrophotometer. Fluorescence measurements were recorded on a Hitachi F-7000 fluorescence spectrophotometer using quartz cuvettes with a path length of $1 \mathrm{~cm}$. Fluorescence quantum yields were determined using absolute PL quantum yield spectrometer (Hamamatsu, Japan). Particle size was measured by dynamic light scattering (DLS) using a Malvern particle analyzer ZEN1690. The fluorimetric assays were carried out by monitoring changes in fluorescence intensity using a Synergy H1 Microplate Reader (BioTek, USA). 


\section{Synthesis of Compounds}

\section{(a) Synthesis of compound 4}

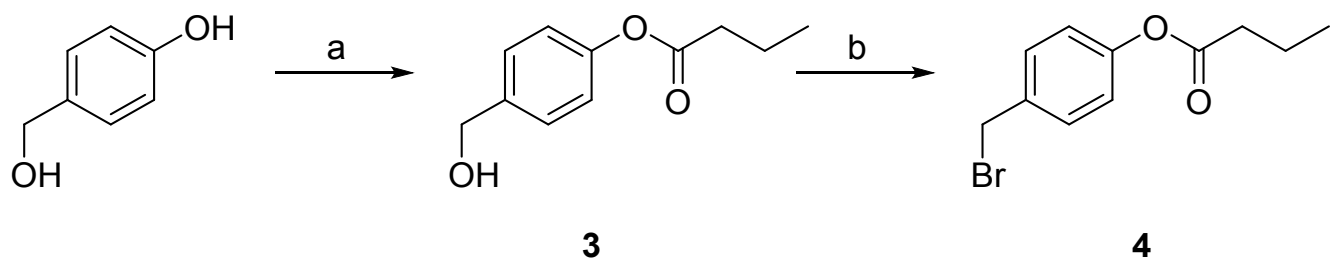

Scheme S1. Synthetic scheme for 4, reagents and conditions. (a) i) butyryl chloride, triethylamine, dry THF, 0 ${ }^{\circ} \mathrm{C}, 2$ hours; ii) RT, 12 hour, $80 \%$. (b) i) $\mathrm{PBr}_{3}$, dry $\mathrm{CH}_{2} \mathrm{Cl}_{2}, 0{ }^{\circ} \mathrm{C}, 2$ hours; ii) RT, 1 hour, $83 \%$.

Compound 3. ${ }^{2}$ To an ice-cold solution of 4-hydroxybenzyl alcohol (2.0 g, $\left.16.1 \mathrm{mmol}\right)$ and triethylamine $(2.49$ $\mathrm{mL}, 17.7 \mathrm{mmol})$ in dry THF $(30 \mathrm{~mL})$ under a nitrogen atmosphere was added dropwise butyryl chloride $(1.8 \mathrm{~mL}$, $17.7 \mathrm{mmol}$ ) over 20 minutes. After stirring at $0{ }^{\circ} \mathrm{C}$ for 2 hours, the resulting mixture was warmed to room temperature, and further stirred for 12 hours. After removing the precipitate by filtration, the filtrate was concentrated under reduced pressure. The crude mixture was diluted with $\mathrm{CH}_{2} \mathrm{Cl}_{2}$, and the organic layer was washed with saturated $\mathrm{NaHCO}_{3}$ solution $(2 \times 30 \mathrm{~mL})$. The collected organic layers were dried over anhydrous $\mathrm{MgSO}_{4}$, filtered, and evaporated under reduced pressure. The crude product was purified by column chromatography on silica gel using progressively more polar 20:1 to 5:1 hexanes:ethyl acetate as the mobile phase to afford compound 3 as a colorless oil $(2.5 \mathrm{~g}, 80 \%) .{ }^{1} \mathrm{H}$ NMR $\left(\mathrm{CDCl}_{3}, 500 \mathrm{MHz}\right): \delta=7.231(\mathrm{~d}, J=8.5$ $\mathrm{Hz}, 2 \mathrm{H}), 6.975(\mathrm{~d}, J=8.5 \mathrm{~Hz}, 2 \mathrm{H}), 4.447(\mathrm{~s}, 2 \mathrm{H}), 3.772(\mathrm{br}, 1 \mathrm{H}), 2.498(\mathrm{t}, J=7.5 \mathrm{~Hz}, 2 \mathrm{H}), 1.771(\mathrm{~m}, 2 \mathrm{H}), 1.032$ $(\mathrm{m}, 3 \mathrm{H}) .{ }^{13} \mathrm{C} \mathrm{NMR}\left(\mathrm{CDCl}_{3}, 125 \mathrm{MHz}\right): \delta=172.595,149.904,138.769,128.038,121.530,64.110,36.226,18.497$, 13.689 .

Compound 4. To a stirred solution of compound $3(2.0 \mathrm{~g}, 10.3 \mathrm{mmol})$ in dry $\mathrm{CH}_{2} \mathrm{Cl}_{2}(30 \mathrm{~mL})$ at $0{ }^{\circ} \mathrm{C}$ under a nitrogen atmosphere was added dropwise $\mathrm{PBr}_{3}(1.0 \mathrm{~mL}, 10.7 \mathrm{mmol})$. After stirring at $0{ }^{\circ} \mathrm{C}$ for 2 hours, the resulting mixture was warmed to room temperature, further stirred for 1 hour, and then quenched by the addition of saturated $\mathrm{NaHCO}_{3}$ solution $(10 \mathrm{~mL})$. The aqueous layer was extracted with $\mathrm{CH}_{2} \mathrm{Cl}_{2}(2 \times 30 \mathrm{~mL})$, and the combinded organic layers were dried over anhydrous $\mathrm{MgSO}_{4}$, filtered, and evaporated under reduced pressure. The crude product was purified by column chromatography on silica gel using progressively more polar 20:1 to 3:1 hexanes:ethyl acetate as the mobile phase to afford compound 4 as a colorless oil $(2.2 \mathrm{~g}, 83 \%)$. ${ }^{1} \mathrm{H}$ NMR $\left(\mathrm{CDCl}_{3}, 400 \mathrm{MHz}\right): \delta=7.40(\mathrm{~d}, J=8.8 \mathrm{~Hz}, 2 \mathrm{H}), 7.058(\mathrm{~d}, J=8.4 \mathrm{~Hz}, 2 \mathrm{H}), 4.484(\mathrm{~s}, 2 \mathrm{H}), 2.537(\mathrm{t}, J=7.6,2 \mathrm{H})$, $1.782(\mathrm{~m}, 2 \mathrm{H}), 1.041(\mathrm{t}, J=7.6,3 \mathrm{H}) .{ }^{13} \mathrm{C} \mathrm{NMR}\left(\mathrm{CDCl}_{3}, 100 \mathrm{MHz}\right): \delta=172.1,150.6,135.2,130.2,122.0,36.2$, 32.8, 18.5, 13.7. HR-MS (ESI): calcd. for $\mathrm{C}_{11} \mathrm{H}_{14} \mathrm{O}_{2} \mathrm{Br}[\mathrm{M}+\mathrm{H}]^{+} 257.0177$, found 257.0176. 
<smiles></smiles>

2

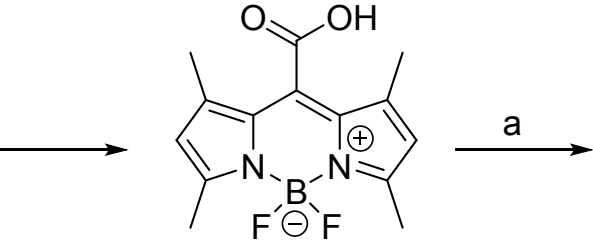

1<smiles></smiles>

B-MC4

Scheme S2. Synthetic scheme for B-MC4, reagents and conditions. (a) 4, $\mathrm{K}_{2} \mathrm{CO}_{3}$, DMF, RT, $5 \mathrm{~h}, 80 \%$.

Probe B-MC4. To a stirred solution of compound $\mathbf{1}^{1}(100 \mathrm{mg}, 0.32 \mathrm{mmol})$ and $\mathrm{K}_{2} \mathrm{CO}_{3}(90 \mathrm{mg}, 0.64 \mathrm{mmol})$ in DMF $(10 \mathrm{~mL})$ at room temperature under a nitrogen atmosphere was added compound $4(114 \mathrm{mg}, 0.38 \mathrm{mmol})$. After the mixture was stirred at room temperature for 5 hours, the reaction solvent was removed under reduced pressure. The crude mixture was diluted with $\mathrm{CH}_{2} \mathrm{Cl}_{2}(20 \mathrm{~mL})$ and washed three times with water $(30 \mathrm{~mL} \times 3)$. The collected organic layers were dried over anhydrous $\mathrm{MgSO}_{4}$, filtered, and evaporated under reduced pressure. The crude product was purified by column chromatography on silica gel using progressively more polar 30:1 to 3:1 hexanes:ethyl acetate as the mobile phase to afford probe B-MC4 as a red solid (120 $\mathrm{mg}, 80 \%) .{ }^{1} \mathrm{H}$ NMR $\left(\mathrm{CDCl}_{3}, 400 \mathrm{MHz}\right): \delta=7.458(\mathrm{~d}, J=8.4 \mathrm{~Hz}, 2 \mathrm{H}), 7.104(\mathrm{~d}, J=8.4 \mathrm{~Hz}, 2 \mathrm{H}), 6.030(\mathrm{~s}, 2 \mathrm{H}), 5.372(\mathrm{~s}, 2 \mathrm{H}), 2.557$ $(\mathrm{d}, J=7.6 \mathrm{~Hz}, 2 \mathrm{H}), 2.516(\mathrm{~s}, 6 \mathrm{H}), 2.001(\mathrm{~s}, 6 \mathrm{H}), 1.796(\mathrm{~m}, 2 \mathrm{H}), 1.044(\mathrm{~m}, 3 \mathrm{H}) .{ }^{13} \mathrm{C} \mathrm{NMR}\left(\mathrm{CDCl}_{3}, 100 \mathrm{MHz}\right): \delta$ $=172.0,165.0,157.7,151.3,141.2,131.1,130.4,128.8,128.6,122.1,121.2,67.9,36.2,18.4,14.8,13.7,12.7$. HR-MS (ESI): calcd. for $\mathrm{C}_{25} \mathrm{H}_{28} \mathrm{BN}_{2} \mathrm{O}_{4} \mathrm{~F}_{2}[\mathrm{M}+\mathrm{H}]^{+} 469.2110$, found 469.2112 . 


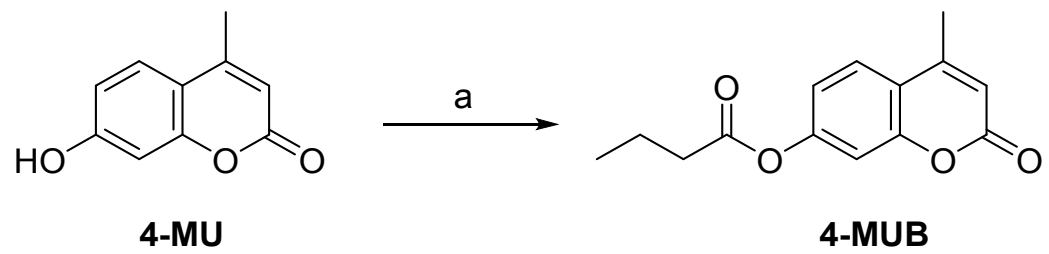

Scheme S3. Synthetic scheme for 4-MUB, reagents and conditions. (a) i) butyryl chloride, triethylamine, 4(dimethylamino)pyridine, dry $\mathrm{THF}, 0{ }^{\circ} \mathrm{C}, 30 \mathrm{~min}$; ii) RT, $6 \mathrm{~h}, 91 \%$.

4-MUB. ${ }^{3}$ To a solution of 4-methyl-7-hydroxycoumarin $(1.1 \mathrm{~g}, 6.24 \mathrm{mmol})$, triethylamine $(1.12 \mathrm{~mL}, 8.02 \mathrm{mmol})$, and 4-(dimethylamino)pyridine $(5 \mathrm{mg})$ in dry THF $(10 \mathrm{~mL})$ at $0{ }^{\circ} \mathrm{C}$ was added a solution of butyryl chloride $(710$ $\mu \mathrm{L}, 6.8 \mathrm{mmol})$ in dry THF $(2 \mathrm{~mL})$. After stirring at $0{ }^{\circ} \mathrm{C}$ for 30 minutes, the reaction mixture was warmed to room temperature, and further stirred for 6 hours. After removing the solvent under reduced pressure, the crude product was purified by column chromatography on silica gel using progressively more polar 10:1 to 1:1 hexanes:ethyl acetate as the mobile phase to afford 4-MUB as a white solid $(1.4 \mathrm{~g}, 91 \%) .{ }^{1} \mathrm{H} \mathrm{NMR}(500 \mathrm{MHz}$, $\left.\mathrm{CDCl}_{3}\right) \delta=7.612(\mathrm{~d}, J=8.5 \mathrm{~Hz}, 1 \mathrm{H}), 7.10(\mathrm{~m}, 2 \mathrm{H}), 6.25(\mathrm{~s}, 1 \mathrm{H}), 2.614(\mathrm{~m}, 2 \mathrm{H}), 2.43(\mathrm{~s}, 3 \mathrm{H}), 1.838(\mathrm{~m}, 2 \mathrm{H})$, $1.071(\mathrm{~m}, 3 \mathrm{H}) .{ }^{13} \mathrm{C}$ NMR $\left(125 \mathrm{MHz}, \mathrm{CDCl}_{3}\right) \delta=171.549,160.587,154.194,153.234,152.116,125.475,118.218$, $117.796,114.456,110.463,36.188,18.368,18.229,13.669$. 


\section{Photophysical Properties of Compounds}

Absorption spectra were obtained on a SCINCO S-3100 spectrophotometer. Fluorescence measurements were recorded on a Hitachi F-7000 fluorescence spectrophotometer using quartz cuvette with a path length of $1 \mathrm{~cm}$. The solutions which form aggregates (B-MC4 and compound 2) were equilibrated for 5 min before measurement.

Table S1. Photophysical properties of compounds

\begin{tabular}{cccccc}
\hline Compounds & Solvent & $\lambda_{\text {abs. } \max }[\mathrm{nm}]$ & $\varepsilon^{b}\left[\mathrm{M}^{-1} \mathrm{~cm}^{-1}\right]$ & $\lambda_{\text {em. } \max }[\mathrm{nm}]^{c}$ & $\Phi_{\mathrm{FL}}{ }^{d}$ \\
\hline B-MC4 & DMSO & 514 & 67,000 & 532 & 0.011 \\
B-MC4 & Buffer $^{a}$ & $535 / 585$ & 27,000 & 588 & 0.027 \\
$\mathbf{2}$ & DMSO & 514 & 86,000 & 534 & 0.012 \\
$\mathbf{2}$ & Buffer $^{a}$ & $522 / 585$ & 39,000 & 588 & 0.050 \\
$\mathbf{1}$ & Buffer $^{a}$ & 496 & 40,000 & 510 & 0.530 \\
\hline
\end{tabular}

${ }^{a}$ Data were obtained in phosphate buffer $\left(10 \mathrm{mM}, \mathrm{pH} 7.4,1 \%\right.$ DMSO, $\left.25{ }^{\circ} \mathrm{C}\right) .{ }^{b}$ Measured at each absorption maximum. ${ }^{c}$ Excited at $460 \mathrm{~nm} .{ }^{d}$ Absolute quantum yields were measured using an integrating sphere.

(a) Spectroscopic properties of probe B-MC4 and the expected hydrolyzed product 1

Absorption and emission spectra of B-MC4 in DMSO and in phosphate buffer solution
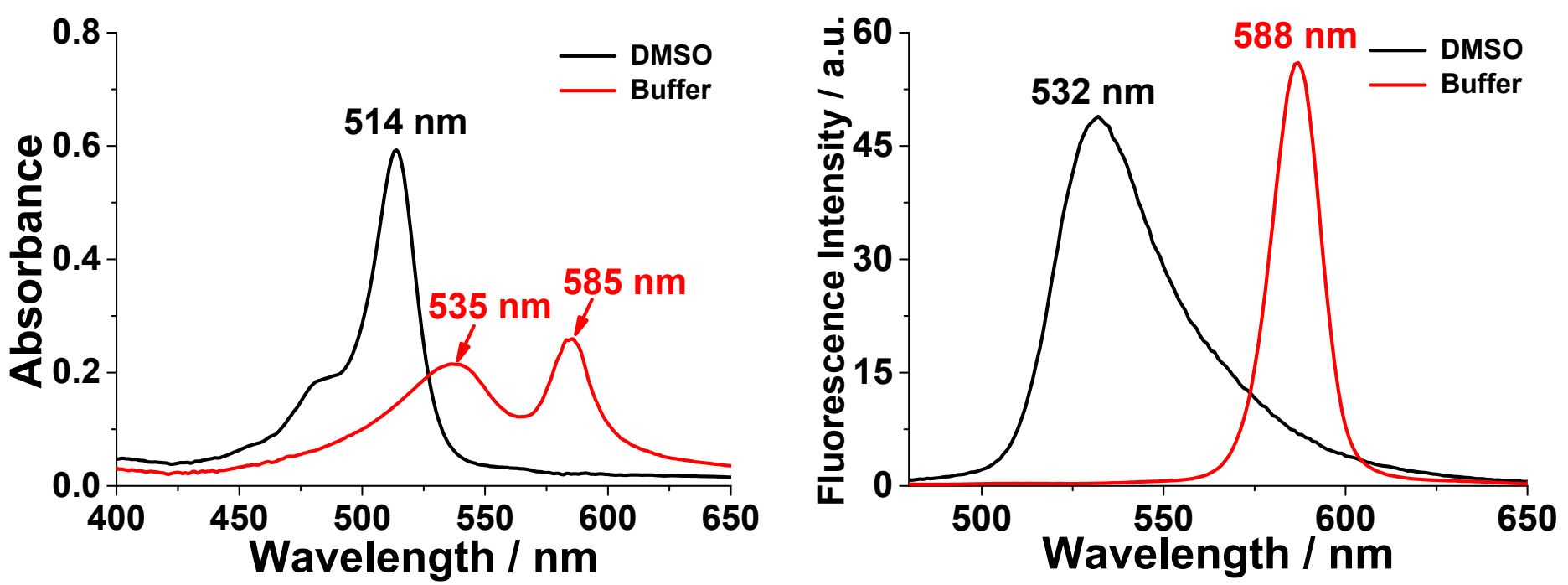

Figure S1. Absorption (left) and fluorescence emission (right) spectra of B-MC4 in DMSO (black) and in phosphate buffer $\left(10 \mathrm{mM}, \mathrm{pH} 7.4,1 \% \mathrm{DMSO}\right.$, red) at $25^{\circ} \mathrm{C}$. Excited at $460 \mathrm{~nm}$. [B-MC4] $=10 \mu \mathrm{M}$. 

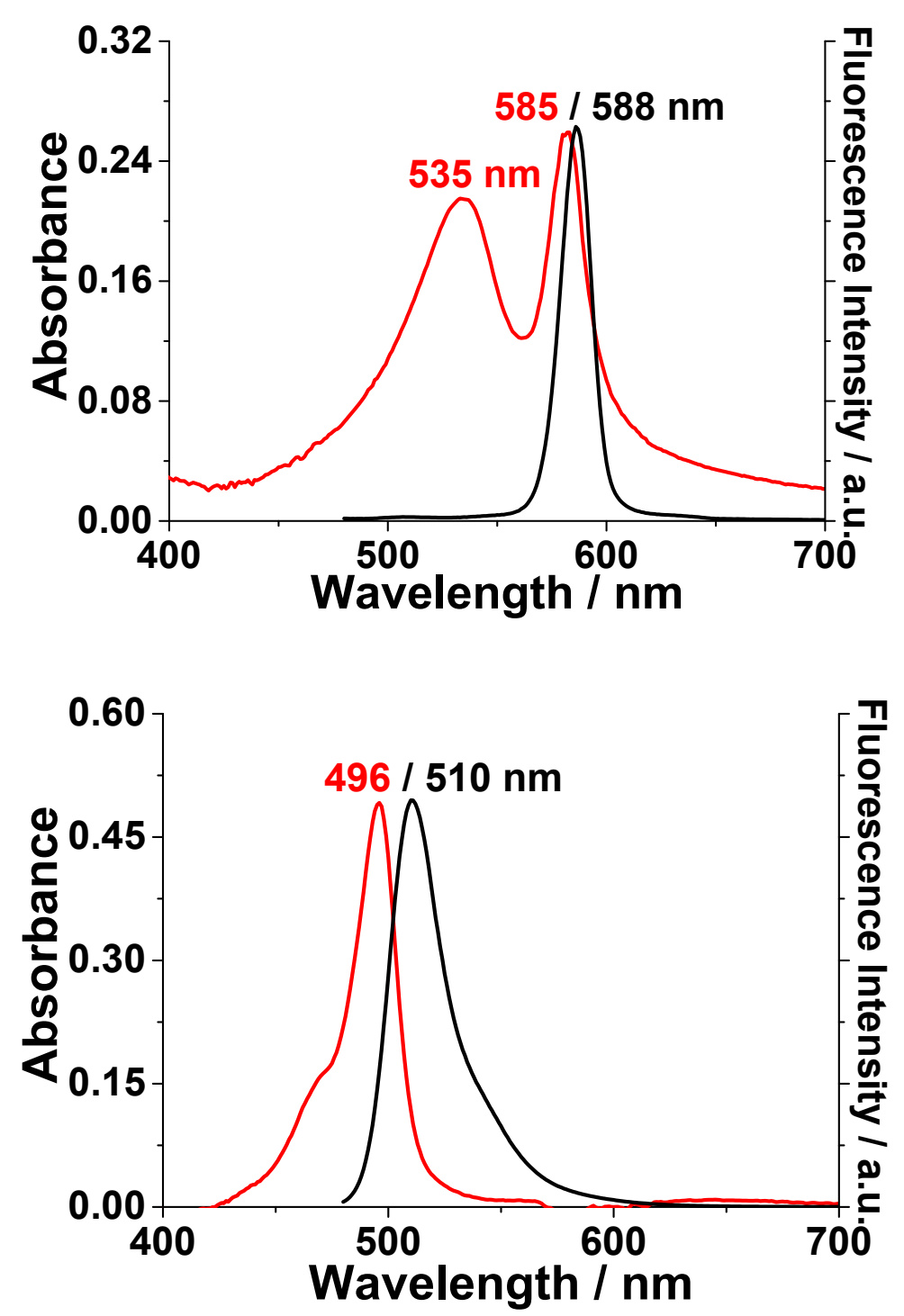

Figure S2. Absorption (red) and fluorescence emission (black) spectra of B-MC4 (top) and 1 (bottom) in phosphate buffer $(10 \mathrm{mM}, \mathrm{pH} 7.4,1 \% \mathrm{DMSO})$ at $25^{\circ} \mathrm{C}$. Excited at $460 \mathrm{~nm}$. [B-MC4] $=[\mathbf{1}]=10 \mu \mathrm{M}$. 

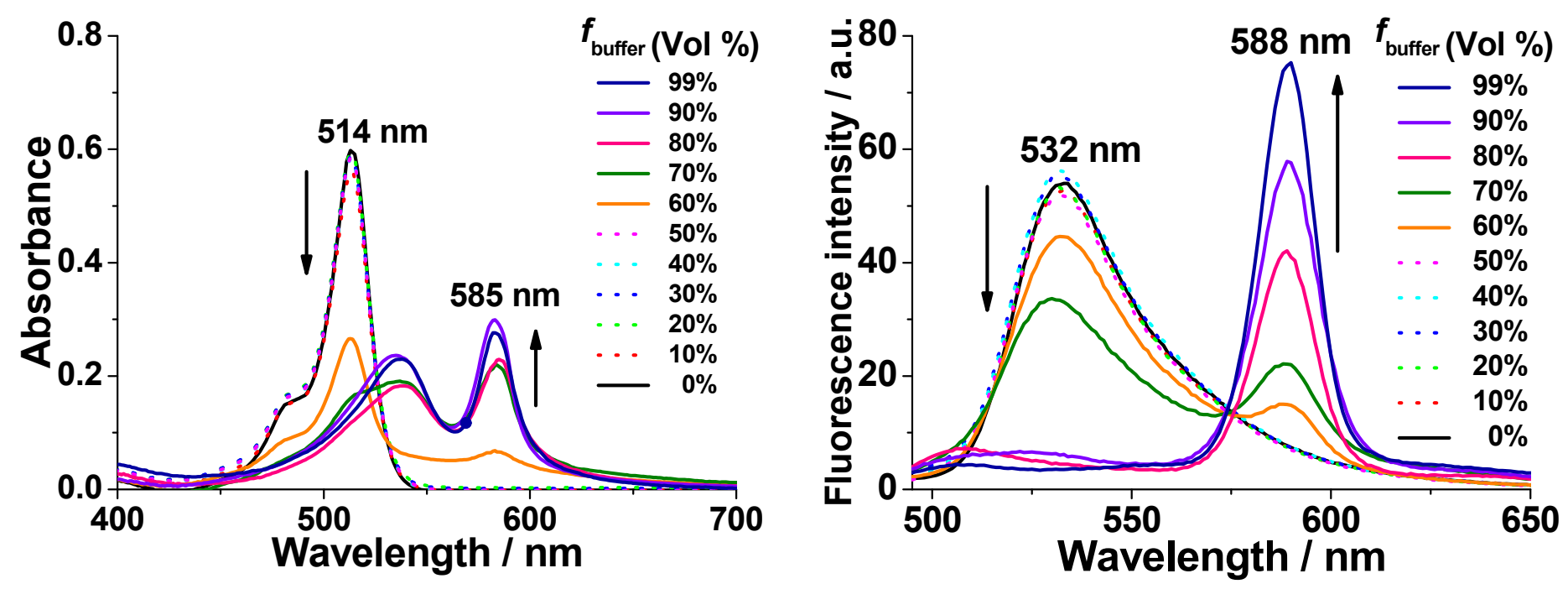

Figure S3. Absorption (left) and fluorescence emission (right) spectra of B-MC4 in DMSO-phosphate buffer (10 $\mathrm{mM}, \mathrm{pH} 7.4)$ mixtures with different buffer fraction ( $f_{\text {buffer }}($ vol \%); $0,10,20,30,40,50,60,70,80,90,99 \%)$ at $25^{\circ} \mathrm{C}$. Excited at $460 \mathrm{~nm}$. 

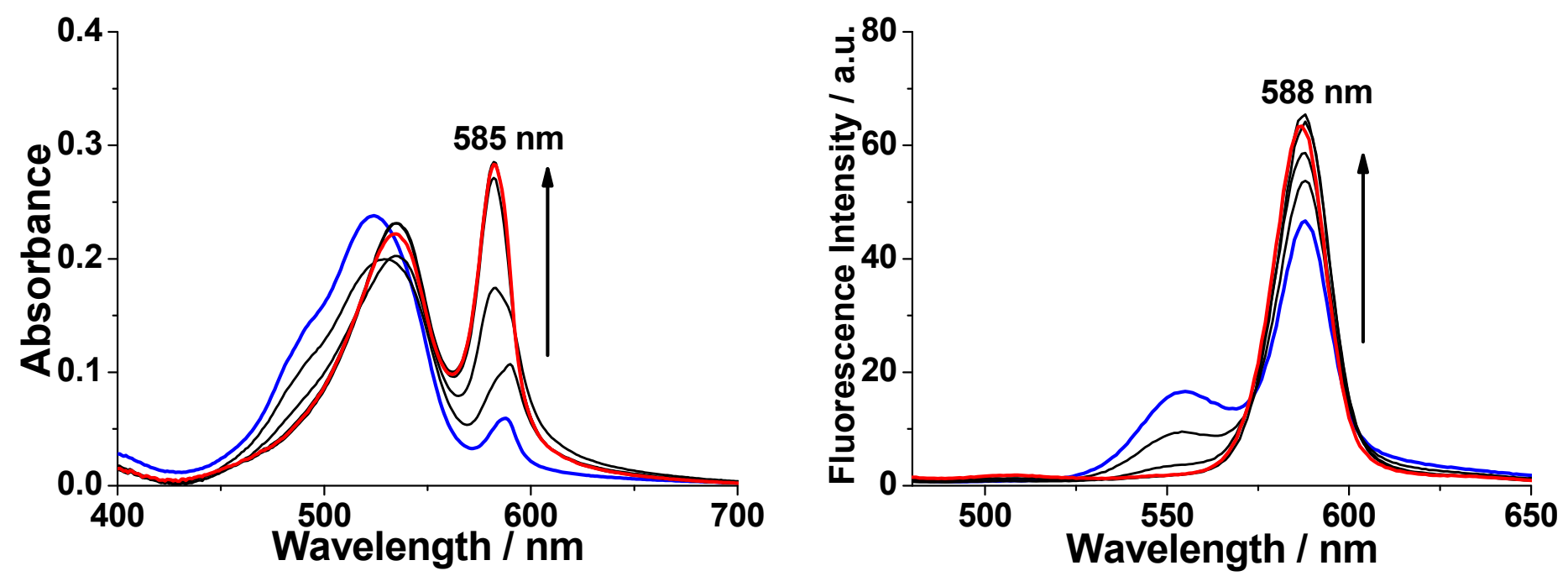

Figure S4. Time-dependent absorption (left) and fluorescence emission (right) spectra of B-MC4 (10 $\mu \mathrm{M})$ in phosphate buffer $(10 \mathrm{mM}, \mathrm{pH} 7.4,1 \% \mathrm{DMSO})$ at $25^{\circ} \mathrm{C}$. The spectra were obtained every $1 \mathrm{~min}(0-5 \mathrm{~min})$. Excited at $460 \mathrm{~nm}$. Blue and red lines indicate spectra of B-MC4 immediately and 5 min after the addition of B-MC4 in aqueous buffer solution, respectively. These results are indicative of the rapid aggregate formation of B-MC4 in aqueous buffer solution.

Absorption, excitation, and emission spectra of $\boldsymbol{B}-\mathbf{M C} 4$ aggregates

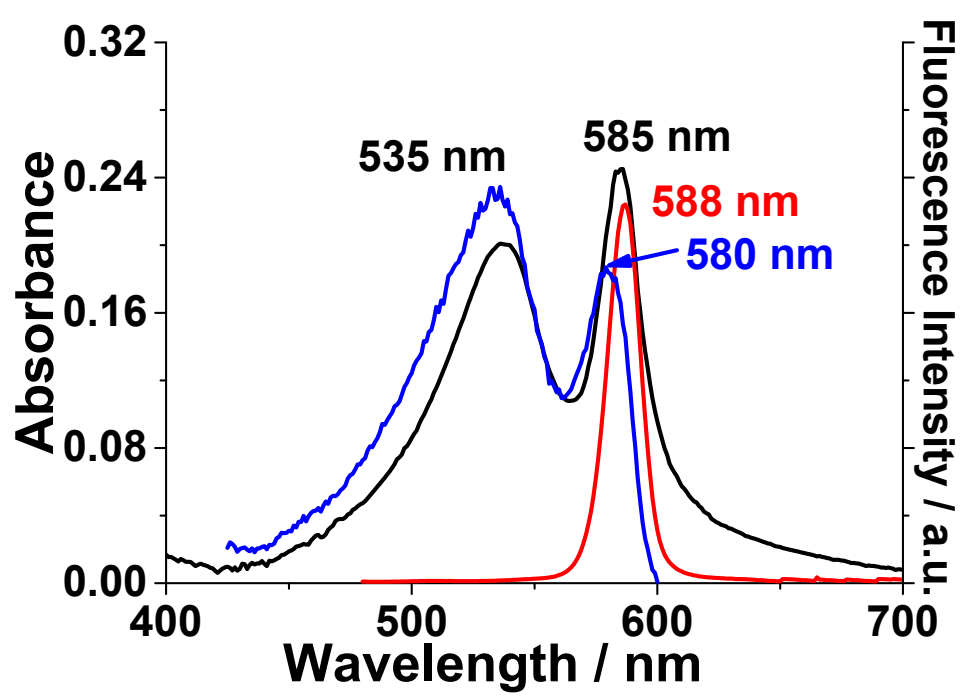

Figure S5. Normalized absorption (black), excitation (blue), and emission (red) spectra of the suspended colloidal aggregates of B-MC4 in phosphate buffer $(10 \mathrm{mM}, \mathrm{pH} 7.4,1 \% \mathrm{DMSO})$ at $25{ }^{\circ} \mathrm{C}$. The excitation spectrum was obtained by monitoring at $650 \mathrm{~nm}$, and the emission spectrum was obtained by excitation at 460 nm. [B-MC4] $=10 \mu \mathrm{M}$. 
Emission spectra of $\boldsymbol{B}-\mathbf{M C} 4$ as a function of $\mathrm{pH}$

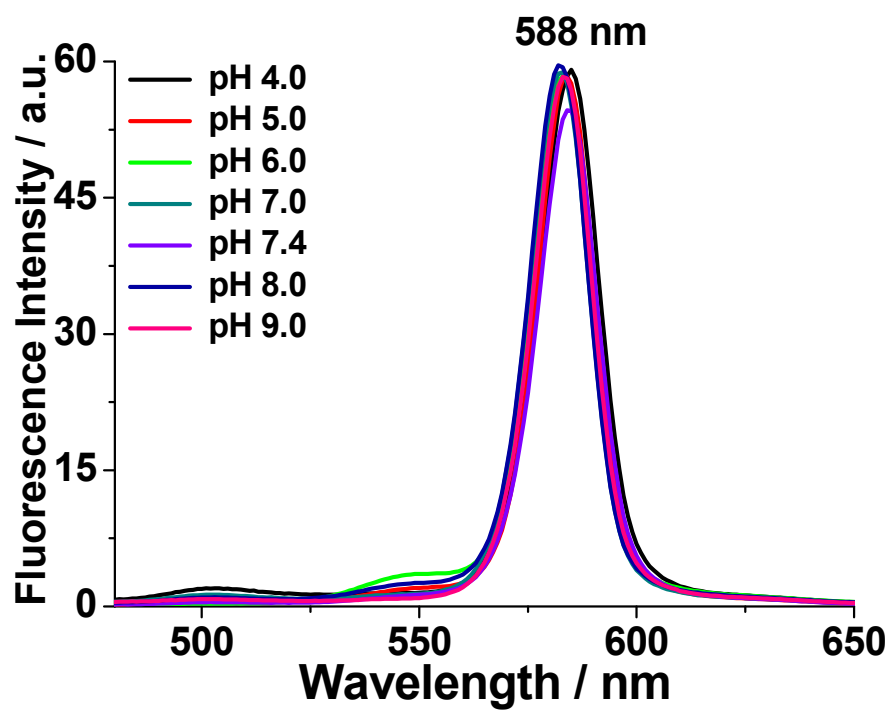

Figure S6. Fluorescence emission spectra of B-MC4 in various $\mathrm{pH}(4-9)$ buffer systems at $25^{\circ} \mathrm{C}$. Each solution includes 1\% DMSO as a cosolvent. Excited at $460 \mathrm{~nm}$. [B-MC4] $=10 \mu \mathrm{M}$.

Emission spectra of 1 as a function of $\mathrm{pH}$
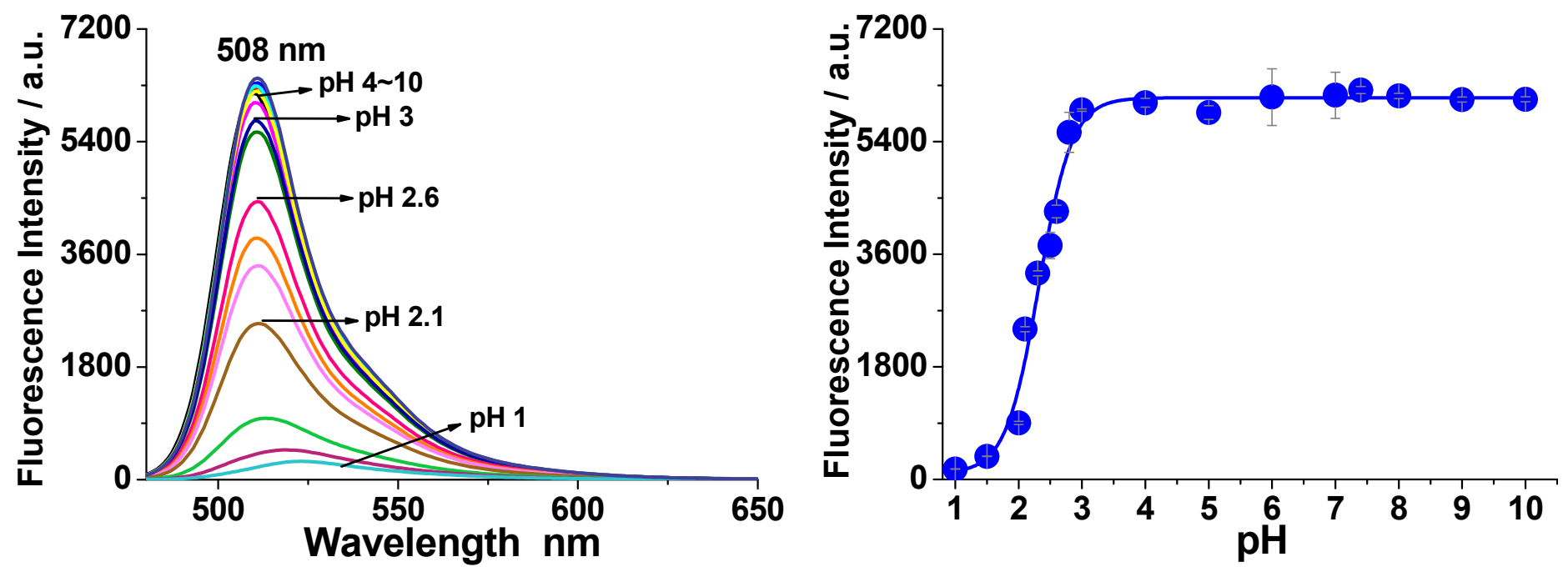

Figure S7. (left) Fluorescence emission spectra and (right) relative fluorescence intensity at $508 \mathrm{~nm}$ of compound 1 in various $\mathrm{pH}(1-10)$ buffer systems at $25^{\circ} \mathrm{C}$. Each solution includes $1 \%$ DMSO as a cosolvent. Excited at 460 nm. $K_{\mathrm{a}}$ of compound 1 is estimated to be $2.4 \pm 0.2$. [1] $=10 \mu \mathrm{M}$. 

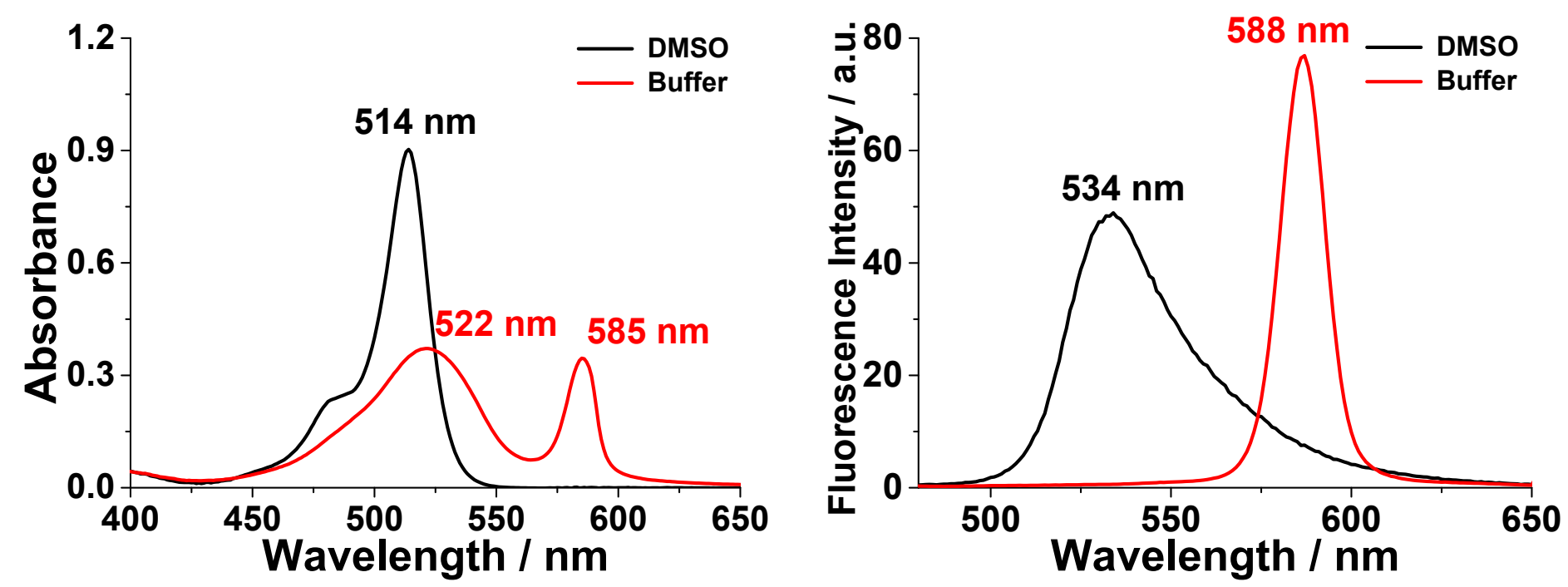

Figure S8. Absorption (left) and fluorescence emission (right) spectra of 2 in DMSO (black) and in phosphate buffer $\left(10 \mathrm{mM}, \mathrm{pH} 7.4,1 \% \mathrm{DMSO}\right.$, red) at $25^{\circ} \mathrm{C}$. Excited at $460 \mathrm{~nm}$. [2] $=10 \mu \mathrm{M}$.

Absorption and emission spectra of 2 in phosphate buffer solution

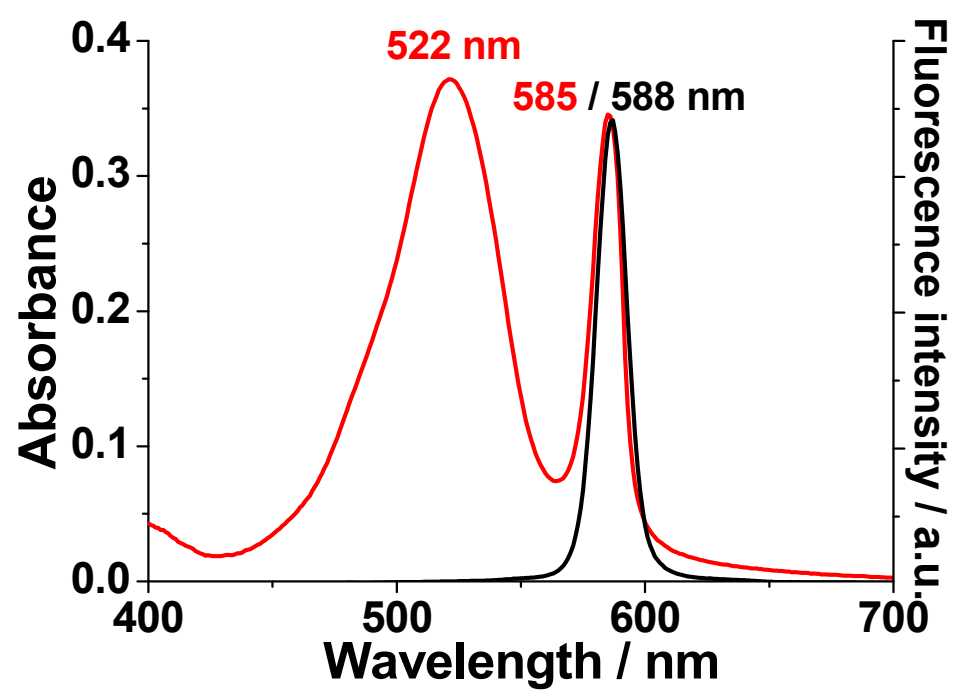

Figure S9. Absorption (red) and fluorescence emission (black) spectra of 2 in phosphate buffer (10 mM, pH 7.4, $1 \%$ DMSO) at $25{ }^{\circ} \mathrm{C}$. Excited at $460 \mathrm{~nm}$. [2] $=10 \mu \mathrm{M}$. 


\section{Stability Studies of B-MC4 and 4-MUB in Aqueous Solution}

Absorption spectra were obtained on a SCINCO S-3100 spectrophotometer. Fluorescence measurements were recorded on a Hitachi F-7000 fluorescence spectrophotometer using quartz cuvette with a path length of 1 $\mathrm{cm}$.

\section{(a) Chemical stability of probes in aqueous buffer solution by absorption and emission spectral monitoring}

To examine the chemical stabilities of probes (B-MC4 and 4-MUB), the absorption and fluorescence emission spectra of each probe in aerated assay solution $(10 \mathrm{mM}$ phosphate buffer, $\mathrm{pH} 7.4,1 \% \mathrm{DMSO})$ at $37{ }^{\circ} \mathrm{C}$ were recorded every 10 min for 1 hour. The chemical stability of B-MC4 was quantified by monitoring the emergence of absorbance at $496 \mathrm{~nm}$ and fluorescence at $508 \mathrm{~nm}$ as a function of incubation time. The chemical stability of 4-MUB was quantified by monitoring the increase in fluorescence at $451 \mathrm{~nm}$ as a function of incubation time.

Monitoring absorption and fluorescence spectral changes of B-MC4 aggregates during 1 h incubation in aqueous solution
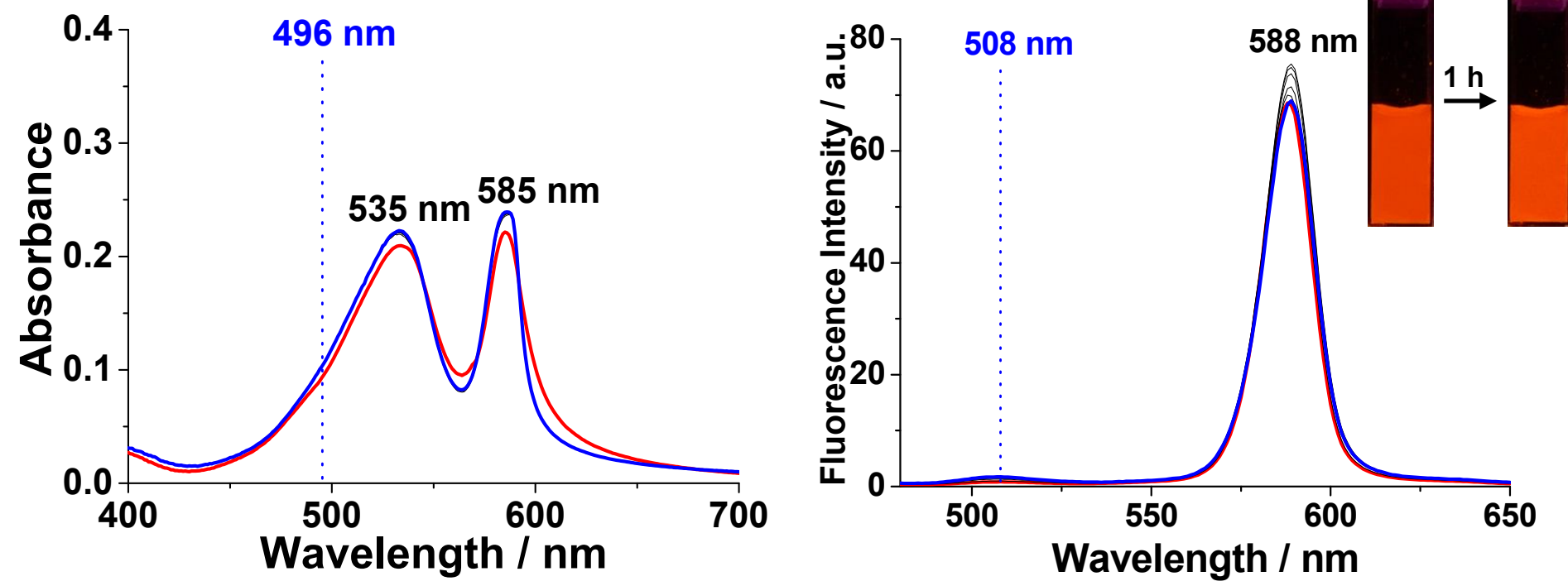

Figure S10. Chemical stability of B-MC4 aggregates in aerated assay solution. Absorbance (left) and fluorescence emission (right) spectra of B-MC4 aggregates were obtained every 10 min for 1 hour. Red and blue solid lines indicate spectra of B-MC4 aggregates before and after $1 \mathrm{~h}$ incubation of B-MC4 in phosphate buffer (10 mM, pH 7.4, 1\% DMSO) at $37{ }^{\circ} \mathrm{C}$, respectively. Blue dotted lines indicates $\lambda_{\max }$ of absorption and fluorescence emission bands of $1\left(\lambda_{\text {abs. } \max }=496 \mathrm{~nm} ; \lambda_{\mathrm{em} \cdot \max }=508 \mathrm{~nm}\right)$. [B-MC4] $=10 \mu \mathrm{M}$. Excited at $460 \mathrm{~nm}$. Insets: Photographs of B-MC4 $(20 \mu \mathrm{M})$ aggregates before (left) and after (right) 60 min incubation in aqueous buffer solution under UV light $(365 \mathrm{~nm})$ irradiation. There is no new absorbance at $496 \mathrm{~nm}$ and emission signal at $508 \mathrm{~nm}$ (dotted-lines), indicative of negligible non-specific hydrolysis of B-MC4 in aqueous assay condition. 

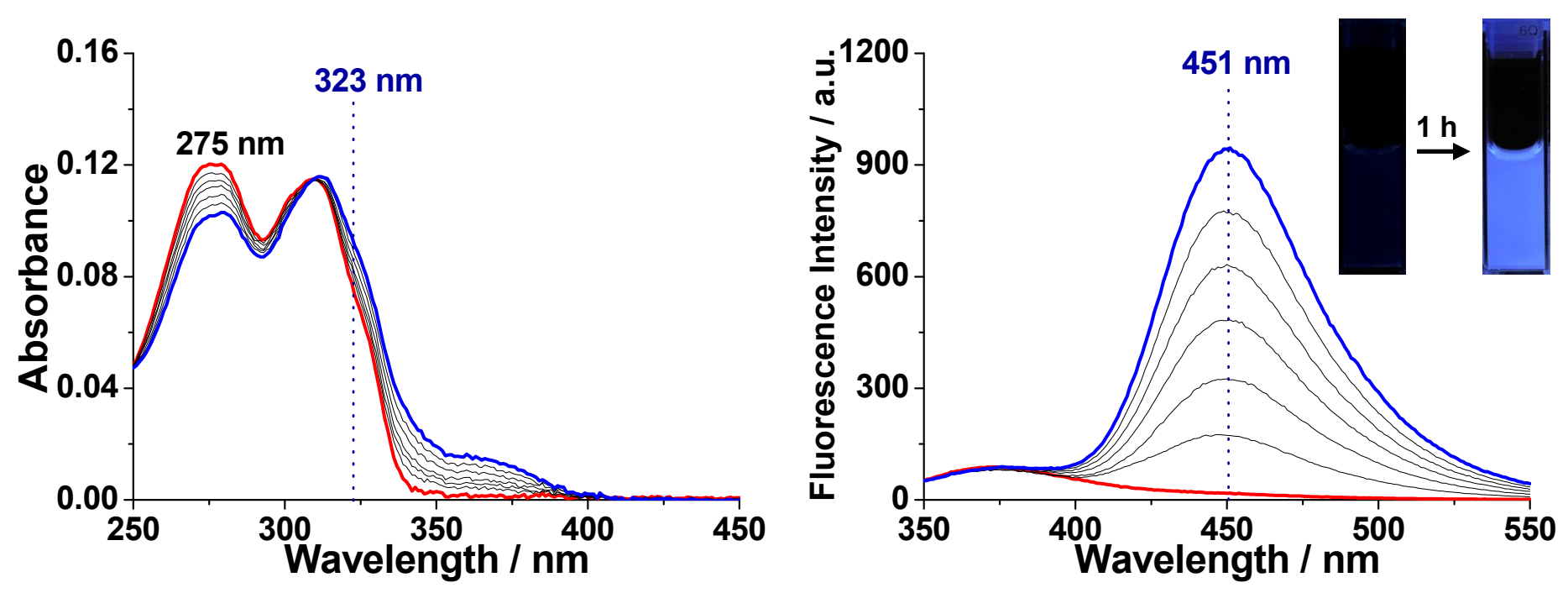

Figure S11. Chemical stability of 4-MUB in aerated assay solution. Absorbance (left) and fluorescence emission (right) spectra of 4-MUB were obtained every $10 \mathrm{~min}$ for 1 hour. Red and blue solid lines indicate spectra of 4MUB before and after $1 \mathrm{~h}$ incubation of 4-MUB in phosphate buffer $(10 \mathrm{mM}, \mathrm{pH} 7.4,1 \% \mathrm{DMSO})$ at $37^{\circ} \mathrm{C}$, respectively. Blue dotted lines indicates $\lambda_{\max }$ of absorption and fluorescence emission bands of 4-MU $\left(\lambda_{\text {abs. } \max }=\right.$ $\left.323 \mathrm{~nm} ; \lambda_{\text {em. } \max }=451 \mathrm{~nm}\right)$. [4-MUB] $=10 \mu \mathrm{M}$. Excited at $300 \mathrm{~nm}$. Insets: Photographs of 4-MUB $(20 \mu \mathrm{M})$ before (left) and after (right) $60 \mathrm{~min}$ incubation in aqueous buffer solution under UV light (365 nm) irradiation. A significant increase in fluorescence intensity at $451 \mathrm{~nm}$ (dotted-line) indicates that 4-MUB undergoes rapid non-specific hydrolysis in aqueous assay condition. 

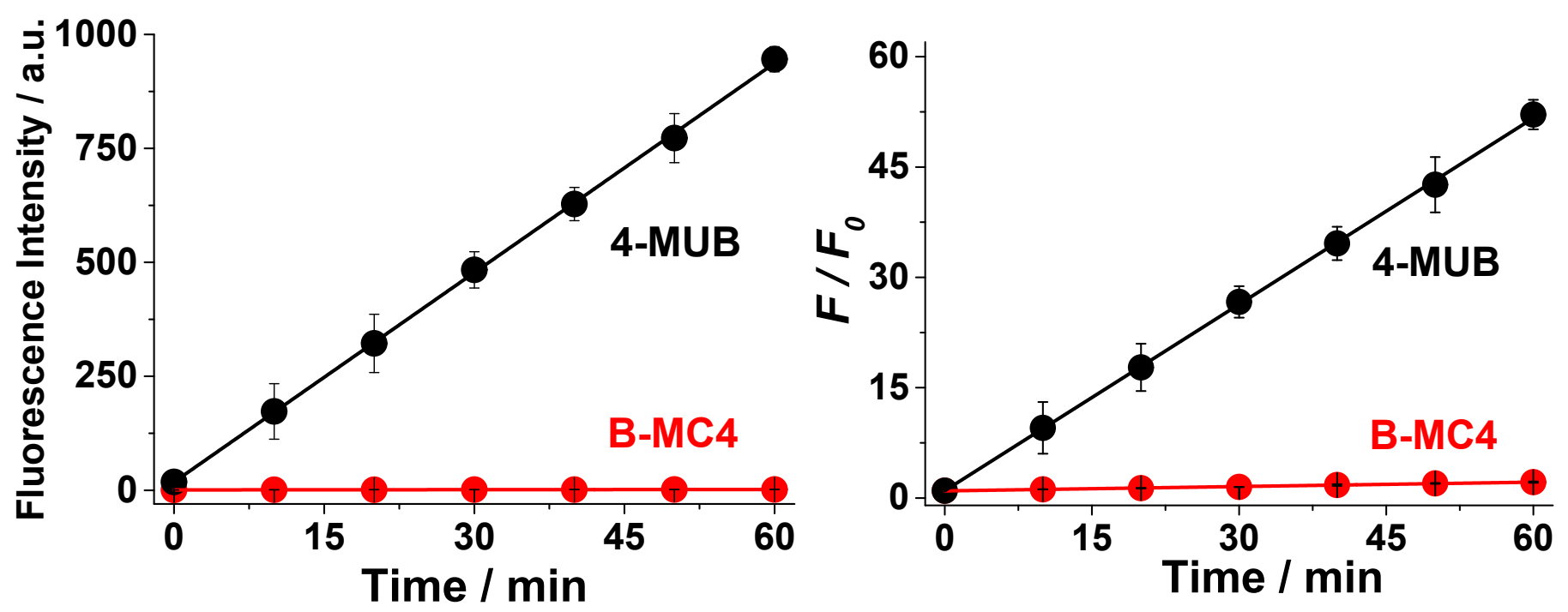

Figure S12. Comparison of chemical stabilities of B-MC4 $(10 \mu \mathrm{M}$, red $)$ and 4-MUB $(10 \mu \mathrm{M}$, black $)$ in phosphate buffer $\left(10 \mathrm{mM}\right.$, pH 7.4, 1\% DMSO) at $37{ }^{\circ} \mathrm{C}$ for 1 hour. Relative fluorescence intensity at $508 \mathrm{~nm}\left(\lambda_{\mathrm{ex}}=460 \mathrm{~nm}\right)$ for B-MC4 and at $451 \mathrm{~nm}\left(\lambda_{\mathrm{ex}}=300 \mathrm{~nm}\right)$ for 4-MUB as a function of incubation time. Error bars indicate \pm standard deviation. 


\section{(b) Chemical stability of probes in aqueous buffer solution by HPLC analysis}

Determination of half-life ( $\left.t_{1 / 2}\right)$ of hydrolysis of probes (B-MC4 and 4-MUB) in aqueous assay solution

The hydrolysis rate constant $(k)$ of B-MC4 $(10 \mu \mathrm{M})$ and 4-MUB $(10 \mu \mathrm{M})$ in phosphate buffer $(10 \mathrm{mM}, \mathrm{pH} 7.4$, $1 \%$ DMSO) was determined by HPLC analysis (Figure S13). After the indicated incubation time, a solution (20 $\mu \mathrm{L}$ ) of each probe (B-MC4 and 4-MUB) was injected for analysis, and the concentrations of the hydrolysis products (1 for B-MC4; 4-MU for 4-MUB) were obtained by the integration of peak area at $t_{\mathrm{R}}=10.075 \mathrm{~min}$ for $\mathbf{1}$ and at $t_{\mathrm{R}}=2.175$ for 4-MU, respectively. The rate constant $(k)$ for the conversion of B-MC4 to 1 was determined by fitting the chromatographic peak area at $t_{\mathrm{R}}=10.075\left(t_{\mathrm{R}}=2.175\right.$ for the conversion of 4-MUB to 4-MU) to the equation 1:

$$
\left.\ln \left[\left(\mathrm{C}_{\max }-\mathrm{C}_{t}\right)\right] / \mathrm{C}_{\max }\right]=-k_{\mathrm{obs}} \cdot t
$$

where $\mathrm{C}_{t}$ is the calculated concentration of $\mathbf{1}$ (or 4-MU) at each time interval $(t)$ measured and $C_{\max }$ is the concentration of the hydrolyzed product $1(10 \mu \mathrm{M}$; or 4-MU) as a function of incubation time in phosphate buffer $(10 \mathrm{mM}, \mathrm{pH} 7.4,1 \% \mathrm{DMSO})$ at $37^{\circ} \mathrm{C}$. Figure $\mathrm{S} 14$ is the pseudo first-order plot for the hydrolysis of probes (BMC4, left; 4-MUB, right). The negative slope of the plot provides the observed rate constant $\left(k_{\mathrm{obs}}\right)$ with value of $0.00267 \mathrm{~h}^{-1}$ for B-MC4 and $0.37891 \mathrm{~h}^{-1}$ for 4-MUB, respectively. The hydrolysis half-life $\left(t_{1 / 2}\right)$ can be expressed as equation 2:

$$
t_{1 / 2}=\ln 2 / k_{\mathrm{obs}}
$$

The hydrolysis half-lives of probes B-MC4 and 4-MUB in buffer solution at $37{ }^{\circ} \mathrm{C}$ are $10.8 \mathrm{~d}$ for B-MC4 and $1.83 \mathrm{~h}$ for 4-MUB, respectively, indicating that B-MC4 is highly stable than 4-MUB in aqueous assay condition. 

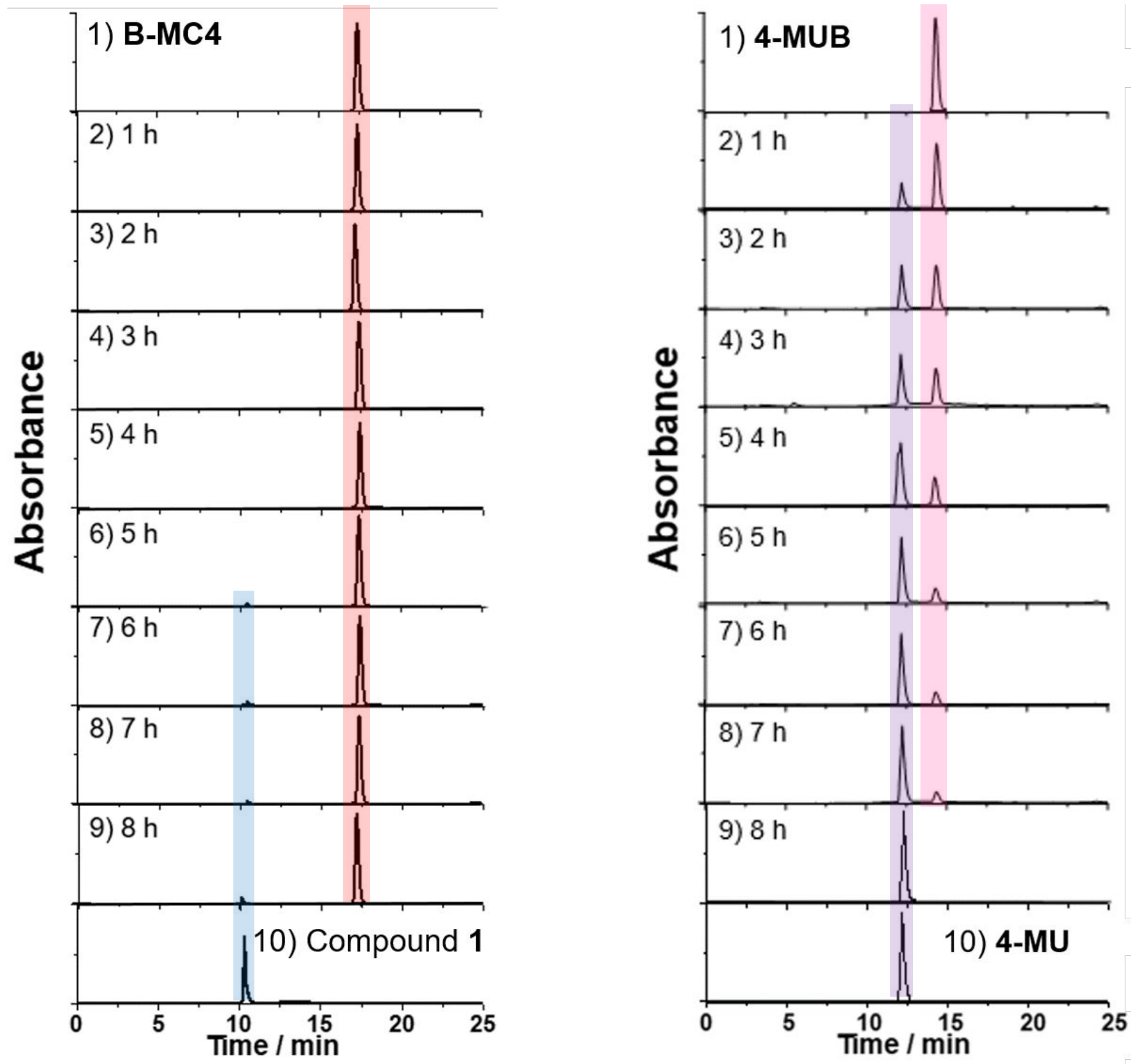

Figure S13. HPLC monitoring of B-MC4 (left) and 4-MUB (right) in phosphate buffer (10 mM, pH 7.4, 1\% DMSO) at $37^{\circ} \mathrm{C}$. All chromatograms were obtained after the incubation of probes (B-MC4 or 4-MUB) in each solution for the indicated time (1-9: 0 to 8 hours). HPLC chromatograms from authentic compound $\mathbf{1}$ and 4-MU are shown in (10). The samples were analyzed by HPLC with a linear gradient elution (from 10 to $100 \%$ B, A: deionized water, B: $\mathrm{CH}_{3} \mathrm{CN}$, flow rate $1 \mathrm{~mL} / \mathrm{min}$, UV-Vis: $500 \mathrm{~nm}$ for B-MC4 and 1, $280 \mathrm{~nm}$ for 4-MUB and 4MU). $[$ B-MC4 $]=[4-M U B]=[1]=[4-M U]=10 \mu \mathrm{M}$. 

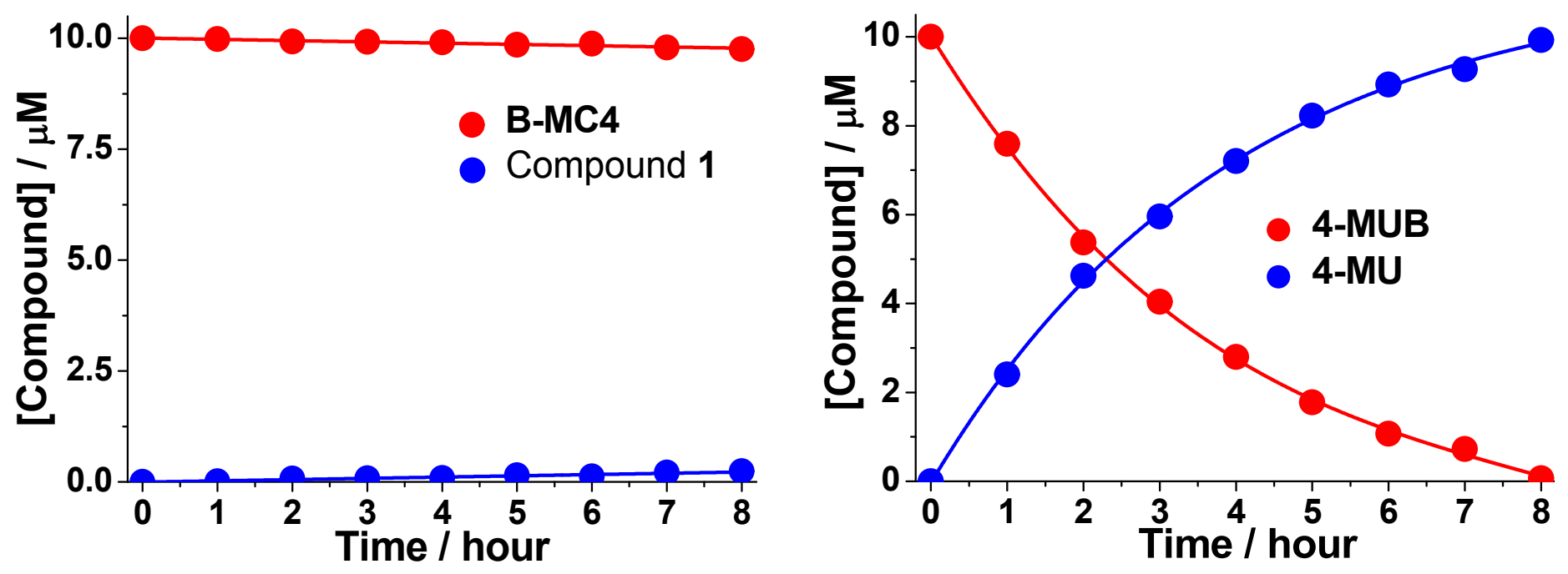

Figure S14. Kinetic curves of the hydrolysis of probes (left, B-MC4; right, 4-MUB) and the formation of the corresponding products (1 for B-MC4; 4-MU for 4-MUB) in phosphate buffer (10 mM, pH 7.4, 1\% DMSO) at $37^{\circ} \mathrm{C}$. Incubation time $=0-8$ hours. $[\mathbf{B}-\mathbf{M C 4}]=[\mathbf{4 - M U B}]=10 \mu \mathrm{M}$. Red and blue lines indicate probes $(\mathbf{B}-\mathbf{M C 4}$, 4-MUB) and the corresponding hydrolyzed products (1, 4-MU), respectively. 

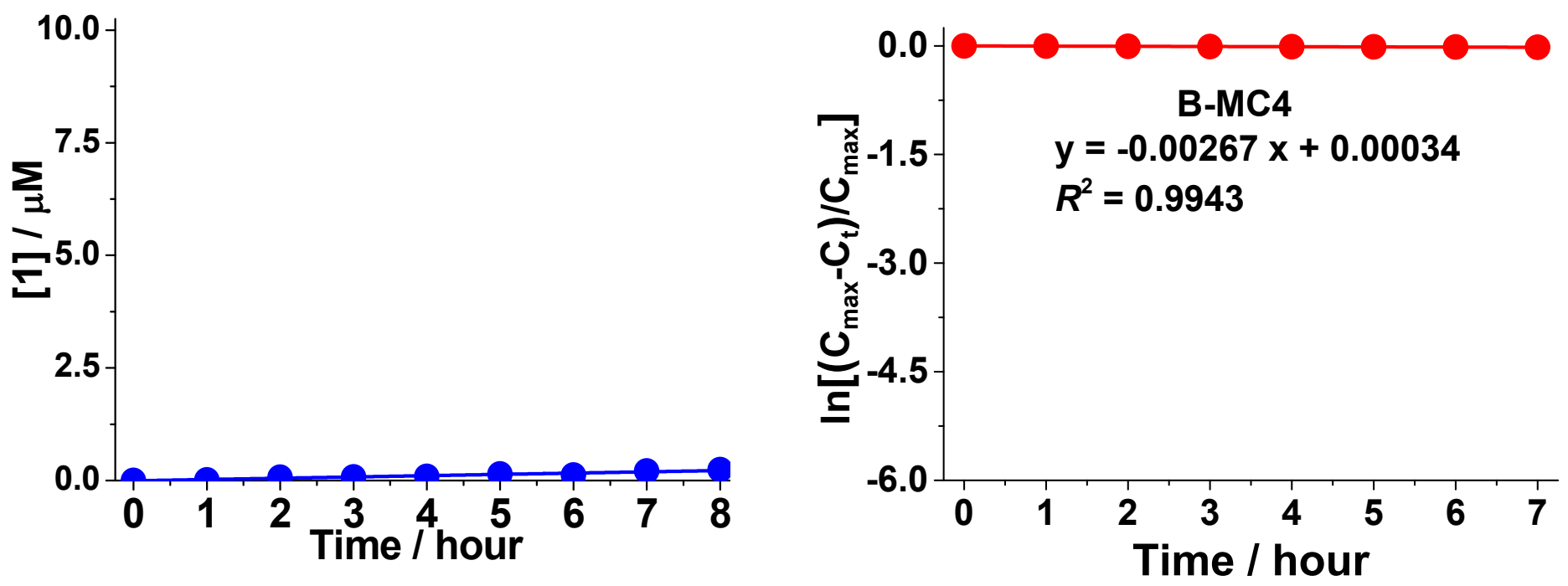

Figure S15. (left) Kinetic curves of the formation of compound $\mathbf{1}$ in phosphate buffer $(10 \mathrm{mM}, \mathrm{pH} 7.4,1 \%$ DMSO) at $37^{\circ} \mathrm{C}$. (right) Pseudo first-order kinetic plot of the hydrolysis of B-MC4 in phosphate buffer (10 mM, $\mathrm{pH} 7.4,1 \% \mathrm{DMSO}$ ) at $37^{\circ} \mathrm{C}$. Incubation time $=0-8$ hours. [B-MC4] $=10 \mu \mathrm{M}$.
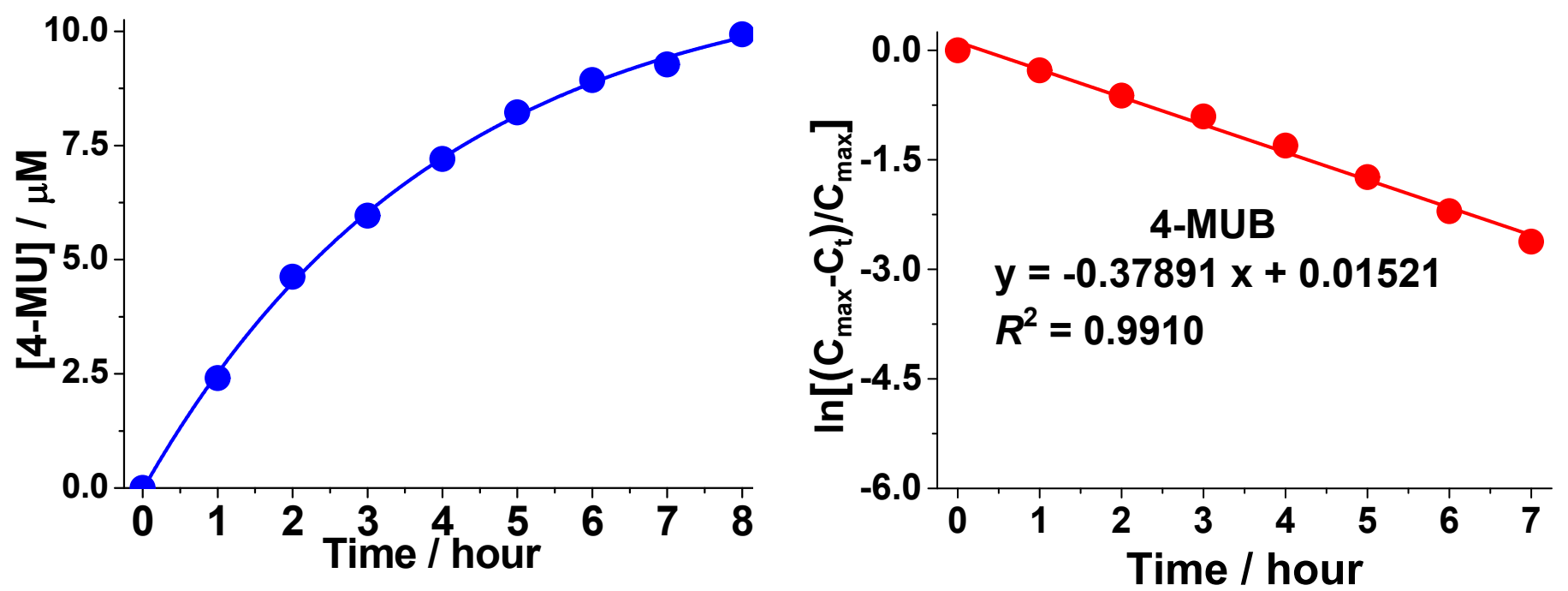

Figure S16. (left) Kinetic curves of the formation of 4-MU in phosphate buffer (10 mM, pH 7.4, 1\% DMSO) at $37^{\circ} \mathrm{C}$. (right) Pseudo first-order kinetic plot of the hydrolysis of 4-MUB in phosphate buffer $(10 \mathrm{mM}, \mathrm{pH} \mathrm{7.4,1 \%}$ DMSO) at $37^{\circ} \mathrm{C}$. Incubation time $=0-8$ hours. [4-MUB] $=10 \mu \mathrm{M}$. 
We have investigated photostabilities of B-MC4 and 1. The photooxidation studies were performed by continuous irradiation $\left(\lambda_{\text {irrad }}=460 \mathrm{~nm}\right)$ using a $150 \mathrm{~W}$ steady-state Xe lamp as the irradiation source under aerobic conditions. The photoinduced degradation was quantified by monitoring absorption and fluorescence emission spectra of B-MC4 and $\mathbf{1}$ as a function of elapsed photolysis time. Negligible changes in absorption and fluorescence emission spectra of B-MC4 and 1 were observed after 3 hours of irradiation, as indicated by Figures S17-18.
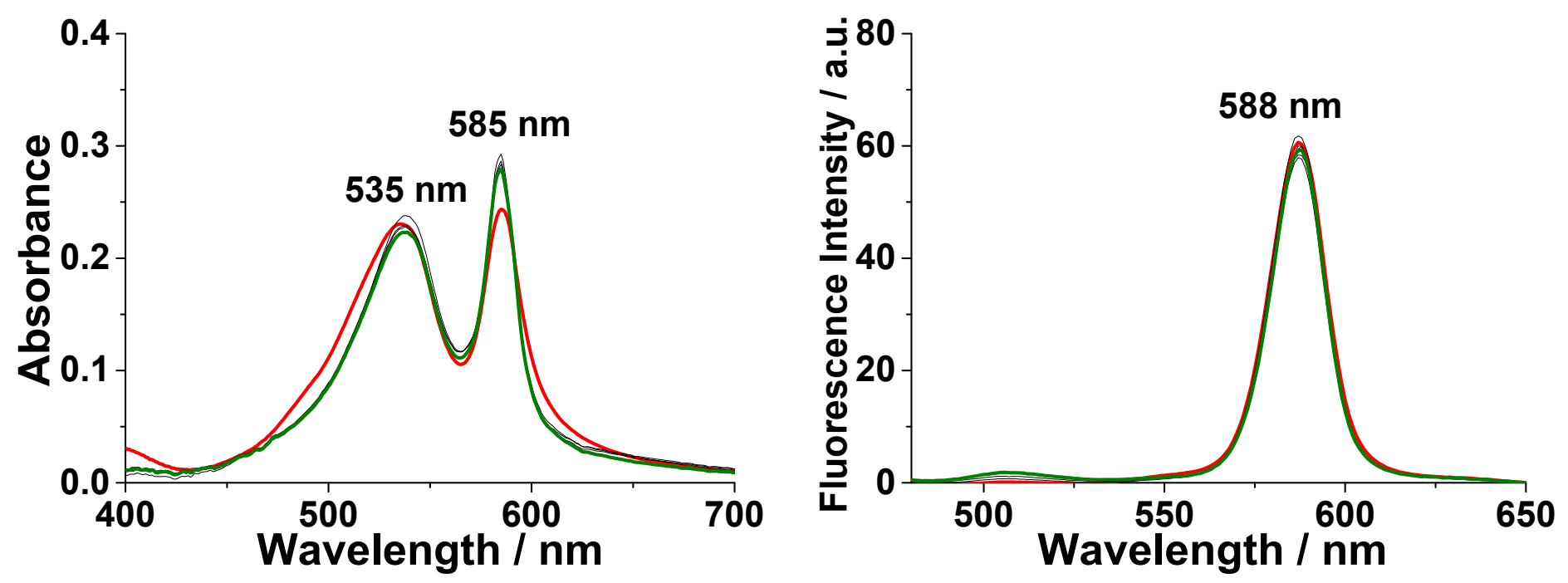

Figure S17. Photostability of compound B-MC4 $(10 \mu \mathrm{M})$ in phosphate buffer $(10 \mathrm{mM}, \mathrm{pH} 7.4,1 \%$ DMSO). Absorbance (left) and fluorescence emission $\left(\lambda_{\mathrm{ex}}=460 \mathrm{~nm}\right.$, right) spectra of B-MC4 were obtained every $30 \mathrm{~min}$ during irradiation of 3 hours. Irradiated at $460 \mathrm{~nm}$. Red and green lines indicate spectra of B-MC4 before and after irradiation of 3 hours. 

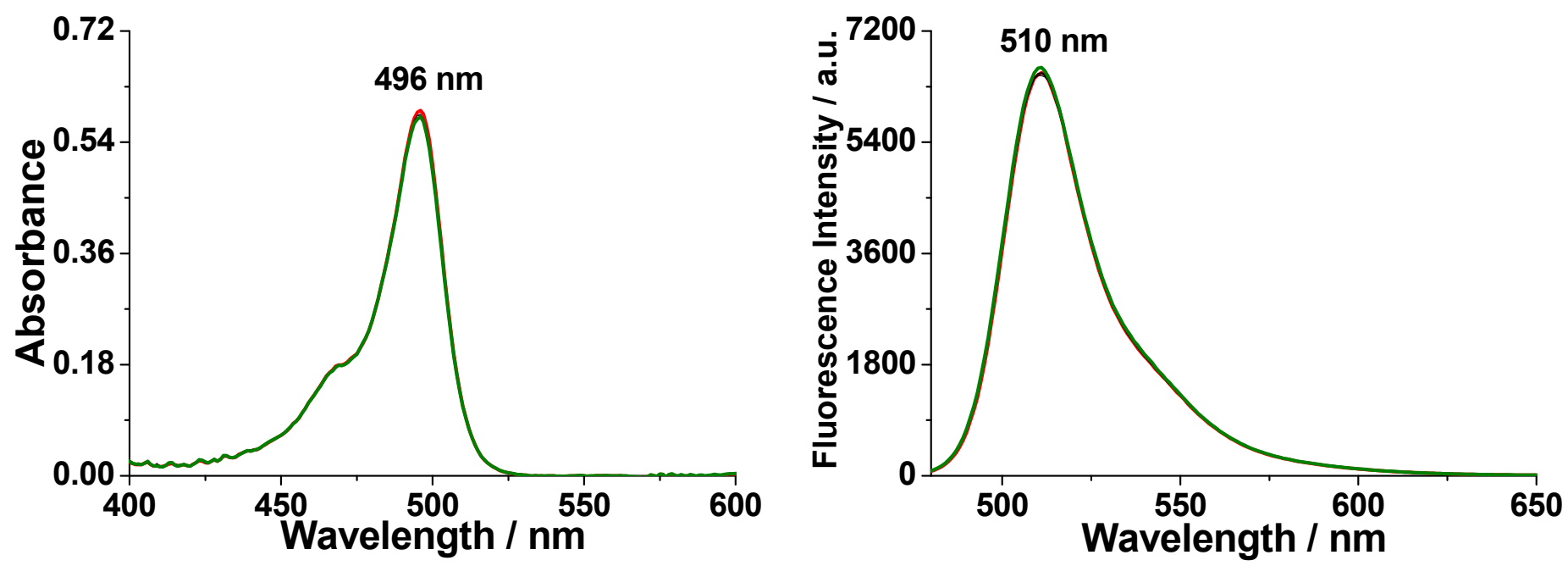

Figure S18. Photostability of compound $1(10 \mu \mathrm{M})$ in phosphate buffer (10 mM, pH 7.4, 1\% DMSO). Absorbance (left) and fluorescence emission ( $\lambda_{\mathrm{ex}}=460 \mathrm{~nm}$, right) spectra of 1 were obtained every 30 min during irradiation of 3 hours. Irradiated at $460 \mathrm{~nm}$. Red and green lines indicate spectra of 1 before and after irradiation of 3 hours. 


\section{Sensory Responses of Probes toward Esterase Activity}

Porcine liver esterase (PLE) was dissolved in phosphate buffer $(10 \mathrm{mM}, \mathrm{pH} 7.4)$ and diluted with the buffer solution to prepare various concentrations of PLE. A solution of B-MC4 (20 $\mu \mathrm{L}$, dissolved in DMSO) was mixed with phosphate buffer $(10 \mathrm{mM}, \mathrm{pH} 7.4,1880 \mu \mathrm{L})$ and incubated for 5 minutes at $25^{\circ} \mathrm{C}$ to stabilize the aggregates. Then, the probe solution was mixed with PLE $(100 \mu \mathrm{L})$ at the indicated concentration. Final concentration of BMC4 was $10 \mu \mathrm{M}$ and the PLE concentrations were $0-1 \mathrm{U} / \mathrm{mL}$. Absorption and fluorescence emission spectra were monitored for $5 \mathrm{~min}$ of incubation at $25^{\circ} \mathrm{C}$, and changes in absorbance at $496 \mathrm{~nm}$ and fluorescence at 508 $\mathrm{nm}$ were recorded. As a reference, the enzymatic hydrolysis of 4-MUB, commercially available fluorogenic substrate, was also investigated under the similar assay conditions. For assays with 4-MUB, absorption and fluorescence emission spectra were monitored for $5 \mathrm{~min}$ of incubation at $25^{\circ} \mathrm{C}$, and changes in fluorescence at $451 \mathrm{~nm}$ were recorded (Figures S27-28). Absorption spectra were obtained on a SCINCO S-3100 spectrophotometer. Fluorescence measurements were recorded on a Hitachi F-7000 fluorescence spectrophotometer using quartz cuvette with a path length of $1 \mathrm{~cm}$.

\section{(a) Enzymatic assay with B-MC4}

Time-dependent sensory response of $\boldsymbol{B}-\mathbf{M C} 4$ toward porcine liver esterase $(0.5 \mathrm{U} / \mathrm{mL})$
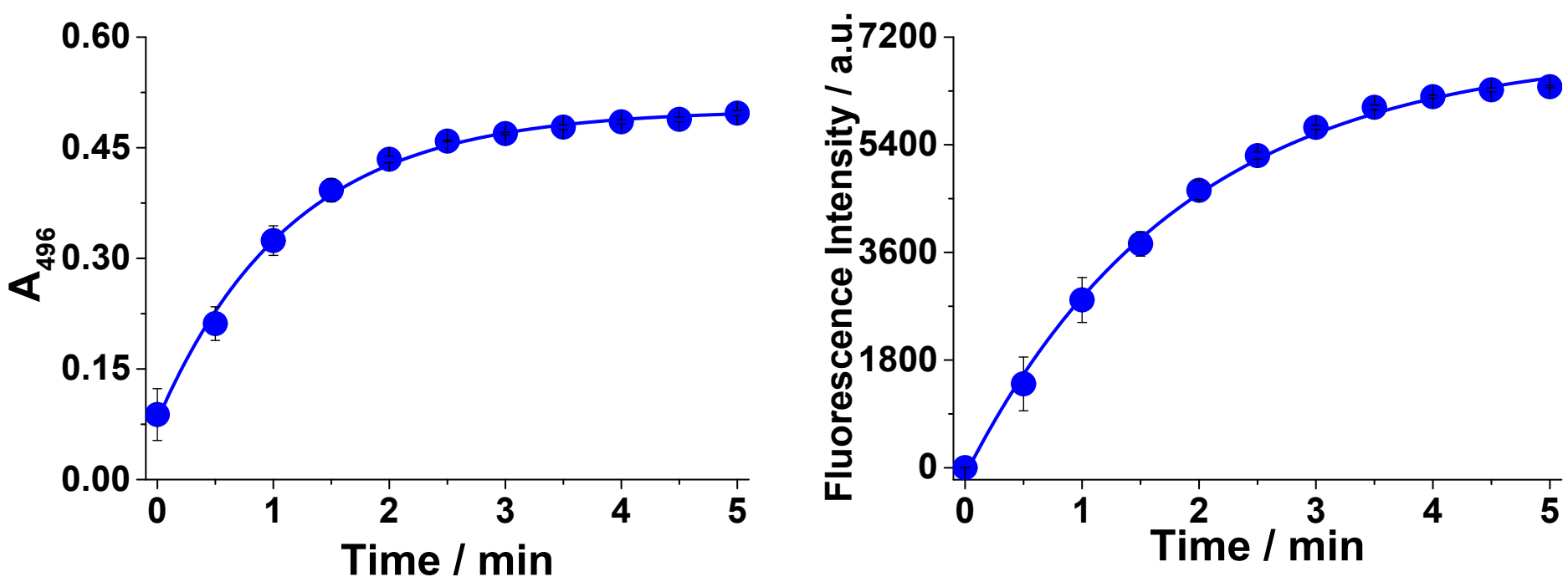

Figure S19. Relative absorbance at $496 \mathrm{~nm}$ (left) and fluorescence intensity at 508 (right) of B-MC4 upon treatment with PLE for different time periods (0-5 min) in phosphate buffer $(10 \mathrm{mM}, \mathrm{pH}=7.4,1 \% \mathrm{DMSO})$ at $25^{\circ} \mathrm{C}$. The spectra were obtained every $30 \mathrm{sec}(0-5 \mathrm{~min})$. [B-MC4] $=10 \mu \mathrm{M}$. [PLE] $=0.5 \mathrm{U} / \mathrm{mL}(=30 \mu \mathrm{g} / \mathrm{mL})$. Excited at $460 \mathrm{~nm}$. Error bars indicate \pm standard deviation. 

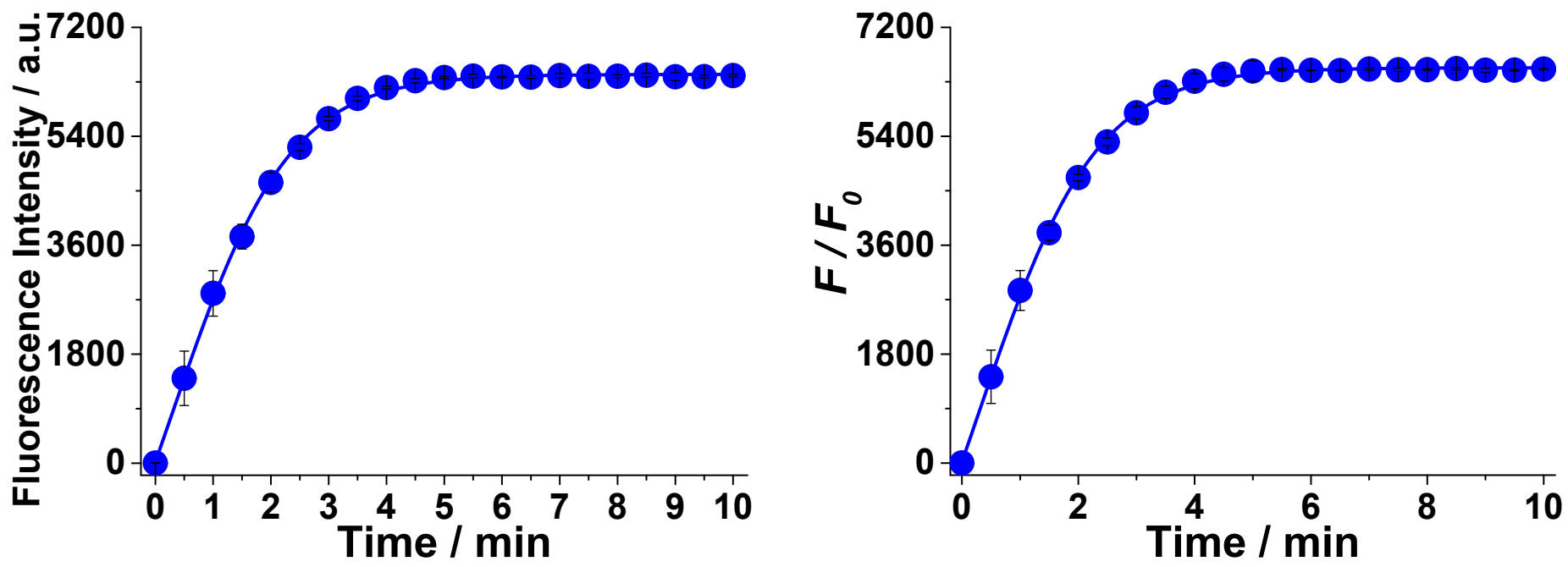

Figure S20. Relative fluorescence intensity at $508 \mathrm{~nm}$ of B-MC4 upon treatment with PLE for different time periods (0-10 min) at $25{ }^{\circ} \mathrm{C}$. The spectra were obtained every $30 \mathrm{sec}(0-10 \mathrm{~min})$ after the addition of PLE to BMC4 in phosphate buffer $(10 \mathrm{mM}, \mathrm{pH}=7.4,1 \% \mathrm{DMSO}) . F_{0}$ and $F$ correspond to the fluorescence intensity of B-MC4 in the absence and the presence of the PLE, respectively. [B-MC4] $=10 \mu \mathrm{M}$. [PLE] $=0.5 \mathrm{U} / \mathrm{mL}(=30$ $\mu \mathrm{g} / \mathrm{mL})$. Excited at $460 \mathrm{~nm}$. Error bars indicate \pm standard deviation.

Effect of pH on fluorescence turn-on responses of probe B-MC4 toward PLE
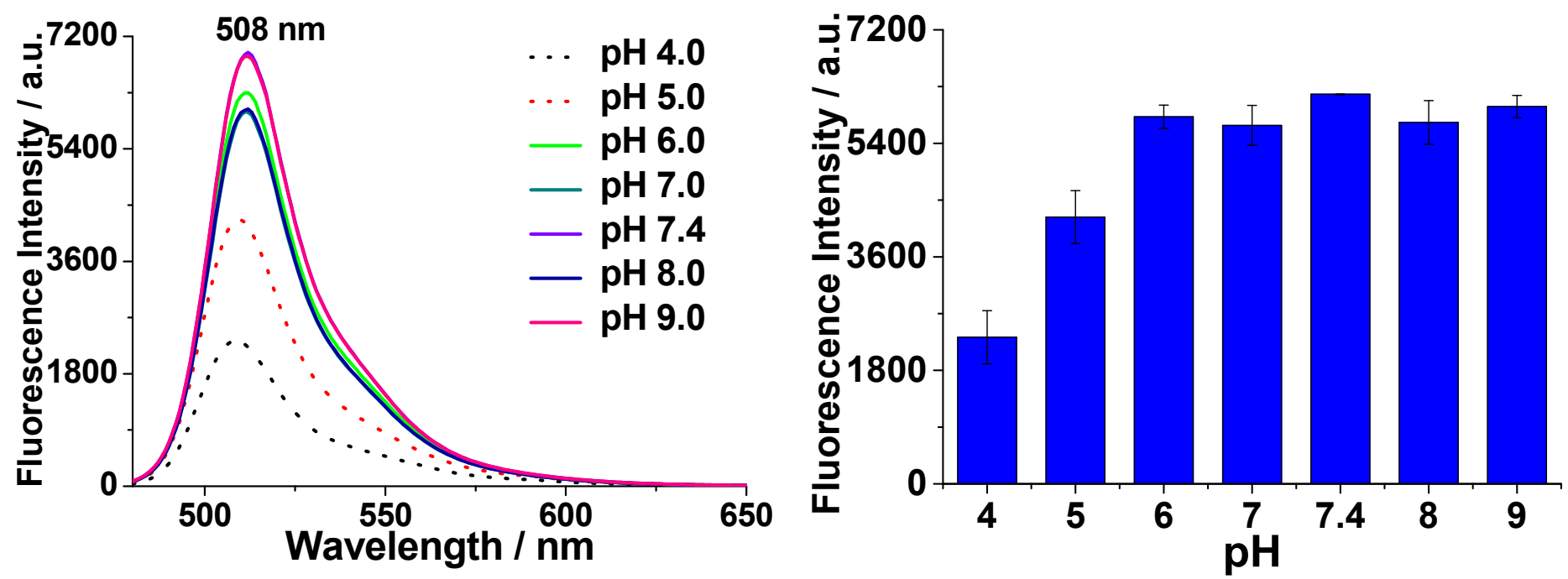

Figure S21. Fluorescence turn-on response of probe B-MC4 $(10 \mu \mathrm{M})$ toward PLE $(0.5 \mathrm{U} / \mathrm{mL})$ in buffer system at different $\mathrm{pH}$ conditions $(4,5,6,7,7.4,8,9)$ at $25^{\circ} \mathrm{C}$. All solutions include $1 \% \mathrm{DMSO}$ as a cosolvent. The emission spectra (left) were obtained after $5 \mathrm{~min}$ incubation with PLE $(0.5 \mathrm{U} / \mathrm{mL})$, and fluorescence intensity at $508 \mathrm{~nm}$ (right) was measured. Excited at $460 \mathrm{~nm}$. Error bars indicate \pm standard deviation. 


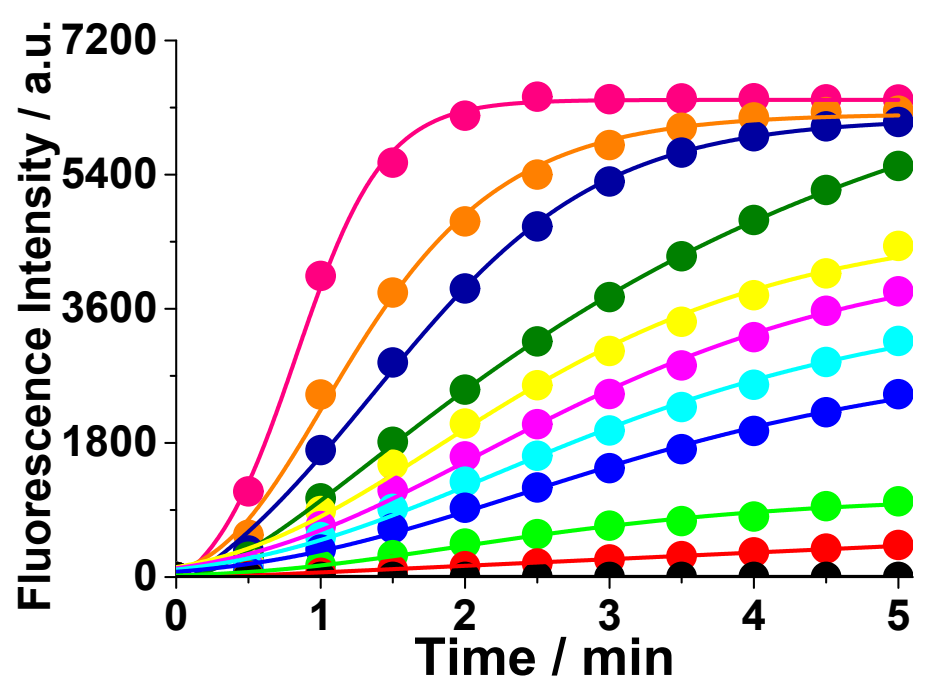

Figure S22. Increases in fluorescence intensity at $508 \mathrm{~nm}$ of B-MC4 as a function of incubation time under varying concentrations of PLE (bottom to top: 0 [control], 0.005, 0.01, 0.025, 0.05, 0.075, 0.1, 0.15, 0.25, 0.5, and $1.0 \mathrm{U} / \mathrm{mL}$ ). Fluorescence measurements were carried out by monitoring fluorescence intensity at $508 \mathrm{~nm}$ using a computer-controlled fluorescence plate reader. The intensities at $508 \mathrm{~nm}$ were recorded every $30 \mathrm{sec}(0-5$ min) after the addition of PLE to B-MC4. [B-MC4] $=10 \mu \mathrm{M}$. Excited at $460 \mathrm{~nm}$. 


\section{(b) Determination of detection limit of B-MC4 toward esterase activity}

The limit of detection (LOD) for the B-MC4-based esterase assay was determined using:

where:

$$
3 \frac{\sigma}{k}
$$

3 is the recommended confidence factor for the LOD (see for example the IUPAC Gold Book DOI: 10.1351/goldbook.R05263)

$\sigma$ is the standard deviation of the blank (obtained from 20 independently prepared blank solutions containing the B-MC4 aggregates, the phosphate buffer (10 mM, pH 7.4, 1\% DMSO), but no added PLE.

$\boldsymbol{k}$ is the sensitivity of the analytical method (i.e. the slope of the calibration curve).

Relative fluorescence intensities at $508 \mathrm{~nm}$ of B-MC4 were monitored $5 \mathrm{~min}$ after the addition of PLE at different concentrations. A linear regression curve was then fitted according to relative fluorescence intensity at $508 \mathrm{~nm}$ as a function of [PLE], and the slope of the curve was obtained.
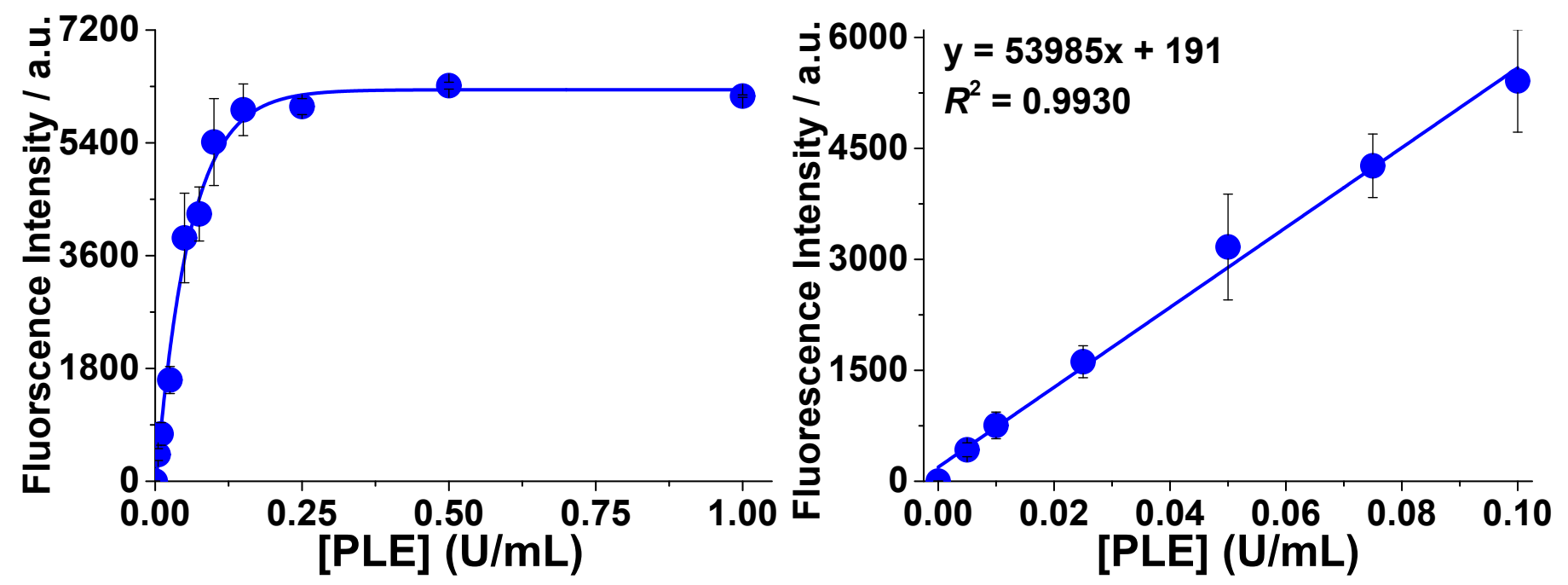

Figure S23. (left) Relative fluorescence intensity at $508 \mathrm{~nm}$ of B-MC4 $(10 \mu \mathrm{M})$ as a function of [PLE] (0-1 $\mathrm{U} / \mathrm{mL}$ ). Incubation time $=5 \mathrm{~min}$. (right) A linear relationship between relative fluorescence intensity at $508 \mathrm{~nm}$ and [PLE] $(0-0.1 \mathrm{U} / \mathrm{mL})$. All measurements were performed in phosphate buffer solution $(10 \mathrm{mM}, \mathrm{pH} \mathrm{7.4,1 \%}$ DMSO) at $25^{\circ} \mathrm{C}$. Excited at $460 \mathrm{~nm}$. Error bars indicate \pm standard deviation. The detection limit $(3 \sigma / \mathrm{slope})$ was determined to be $0.063 \pm 0.004 \mathrm{mU} / \mathrm{mL}(=0.022 \pm 0.0012 \mathrm{nM})$ for PLE. 


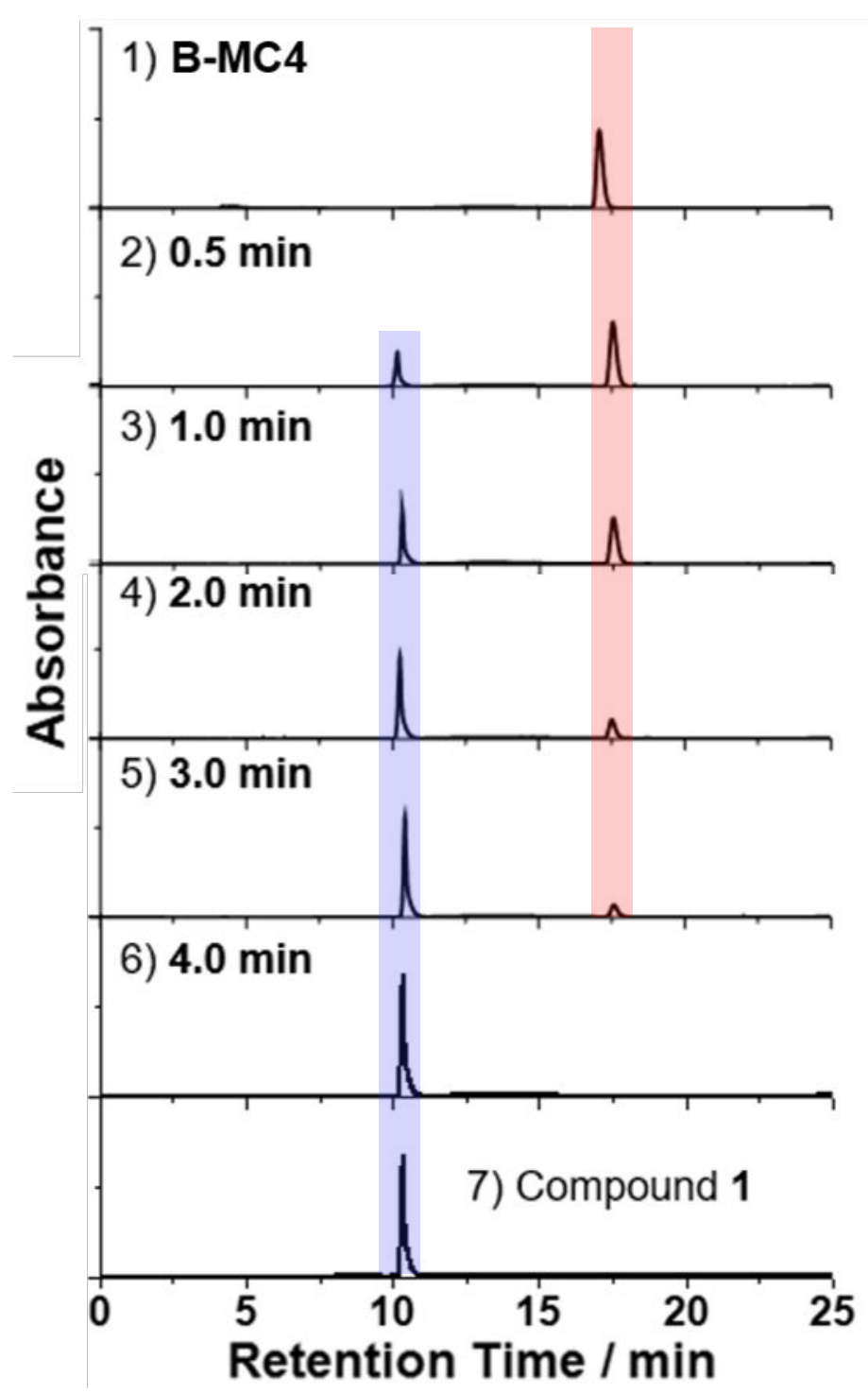

Figure S24. HPLC chromatograms of B-MC4 before (1) and after the treatment with PLE $(0.5 \mathrm{U} / \mathrm{mL})$ for the indicated incubation time (2-5: $0.5,1,2,3$, and $4 \mathrm{~min}$, respectively), and compound 1 only (7). The enzymatic

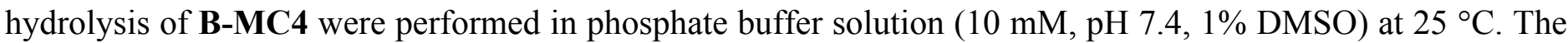
samples were analyzed by HPLC with a linear gradient elution (from $10 \%$ to $100 \% \mathrm{~B}$, A: deionized water, B: $\mathrm{CH}_{3} \mathrm{CN}$, flow rate $\left.1 \mathrm{~mL} / \mathrm{min}, \mathrm{UV}-\mathrm{Vis}: 500 \mathrm{~nm}\right)$. [B-MC4] $=[\mathbf{1}]=10 \mu \mathrm{M}$. 


\section{(d) Control experiment:}

Sensory response of 2 toward PLE (1 U/mL) for 2 hours

As a control, the enzymatic hydrolysis of 2 was also investigated under the similar assay conditions (10 $\mathrm{mM}$

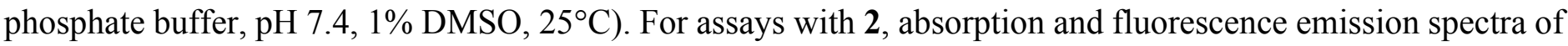
$2(10 \mu \mathrm{M})$ upon incubation with PLE $(1 \mathrm{U} / \mathrm{mL})$ were monitored for 2 hours. As shown in Figure S25, absorption and emission peaks $\left(\lambda_{\mathrm{abs}, \max }=496 \mathrm{~nm}, \lambda_{\mathrm{em}, \max }=508 \mathrm{~nm}\right)$ of 1 were not observed.
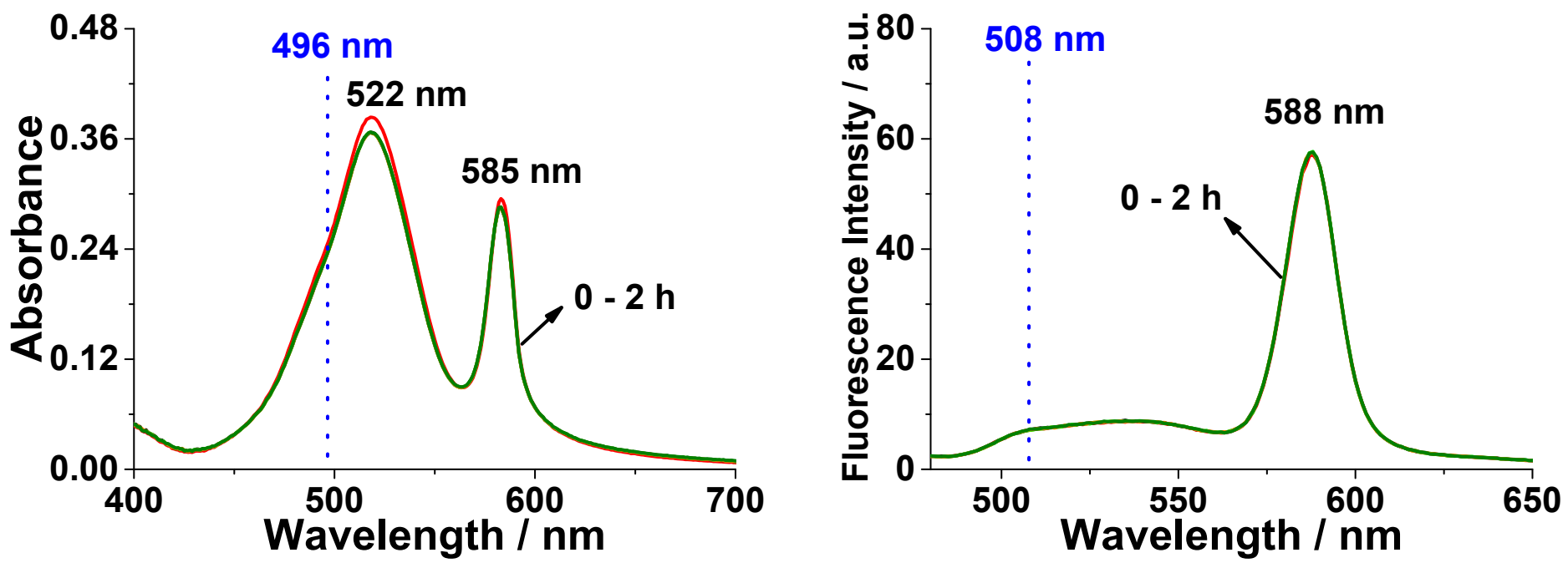

Figure S25. Time-dependent (0-120 min) absorption (left) and fluorescence emission (right) spectra of 2 (10 $\mu \mathrm{M})$ upon treatment with PLE $(1 \mathrm{U} / \mathrm{mL})$ in phosphate buffer $(10 \mathrm{mM}, \mathrm{pH} 7.4,1 \% \mathrm{DMSO})$ at $25^{\circ} \mathrm{C}$. The spectra were obtained every $30 \mathrm{~min}(0-120 \mathrm{~min})$ after addition of PLE to 2 . Excited at $460 \mathrm{~nm}$. 

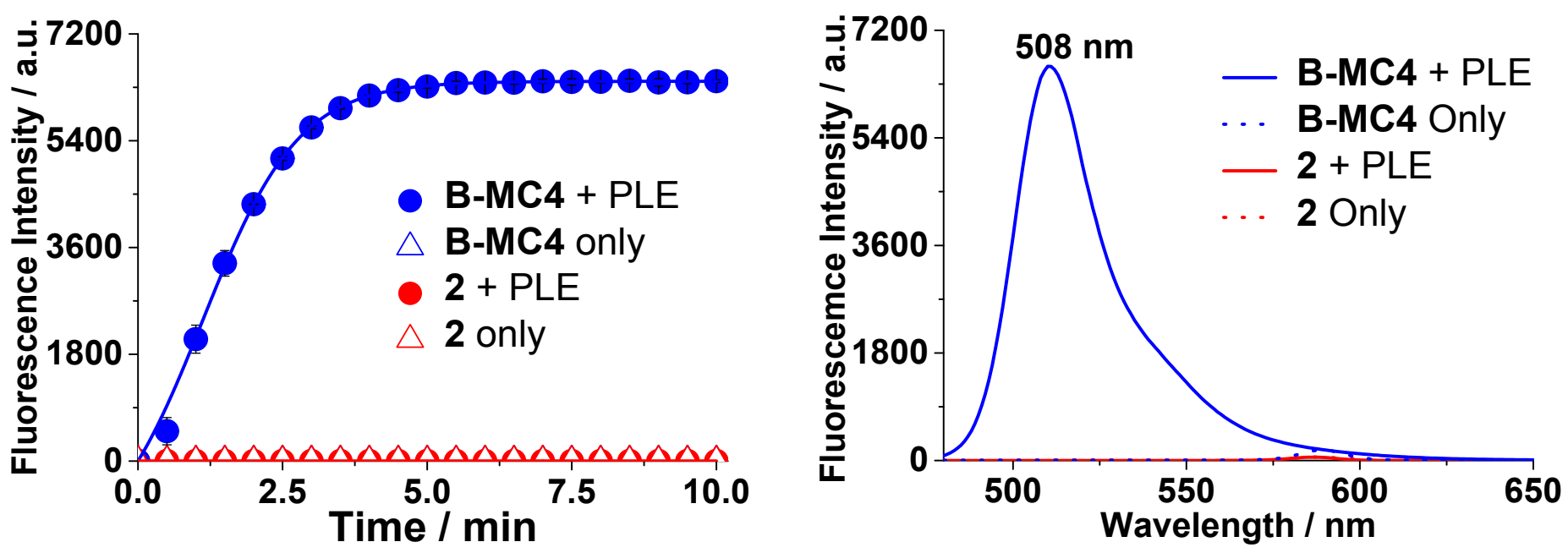

Figure S26. (left) Relative fluorescence intensity at $508 \mathrm{~nm}$ of B-MC4 (blue) and 2 (red) upon treatment with PLE (filled circles) for different time periods $(0-10 \mathrm{~min})$ at $25^{\circ} \mathrm{C}$. The spectra were obtained every $1 \mathrm{~min}(0-10$ $\mathrm{min}$ ) after the addition of PLE to B-MC4 in phosphate buffer (10 $\mathrm{mM}, \mathrm{pH}=7.4,1 \% \mathrm{DMSO})$. The fluorescence intensity of at $508 \mathrm{~nm}$ of B-MC4 (blue) and $\mathbf{2}$ (red) in the absence of the PLE (empty triangles) were monitored in the assay condition for $10 \mathrm{~min}$. [B-MC4] $=10 \mu \mathrm{M}$. [PLE] $=0.5 \mathrm{U} / \mathrm{mL}$ for B-MC4 and $1 \mathrm{U} / \mathrm{mL}$ for 2. Excited at $460 \mathrm{~nm}$. Error bars indicate \pm standard deviation. (right) Fluorescence emission spectra B-MC4 (blue) and 2 (red) before (dotted lines) and after (solid lines) 10 min incubation with PLE. 
(e) Enzymatic assay with 4-MUB (as a reference)

Time-dependent sensory response of 4-MUB toward PLE (0.5 U/mL)
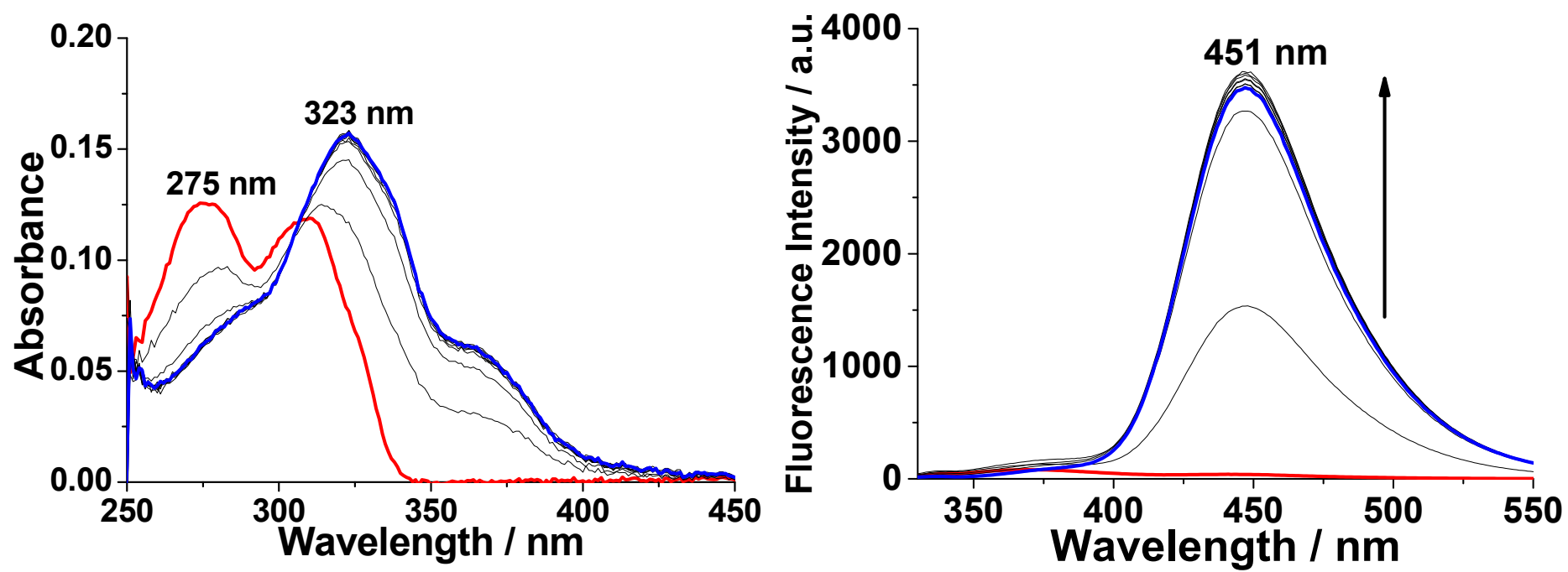

Figure S27. Time-dependent (0-5 min) absorption (left) and fluorescence emission (right) spectra of 4-MUB (10 $\mu \mathrm{M})$ upon treatment with PLE $(0.5 \mathrm{U} / \mathrm{mL})$ in phosphate buffer $(10 \mathrm{mM}, \mathrm{pH} 7.4,1 \% \mathrm{DMSO})$ at $25^{\circ} \mathrm{C}$. The spectra were obtained every $30 \mathrm{sec}(0-5 \mathrm{~min})$ after addition of PLE to 4-MUB. Excited at $300 \mathrm{~nm}$. Red and blue lines indicate spectra of 4-MUB before and after 5 min incubation with PLE, respectively. 


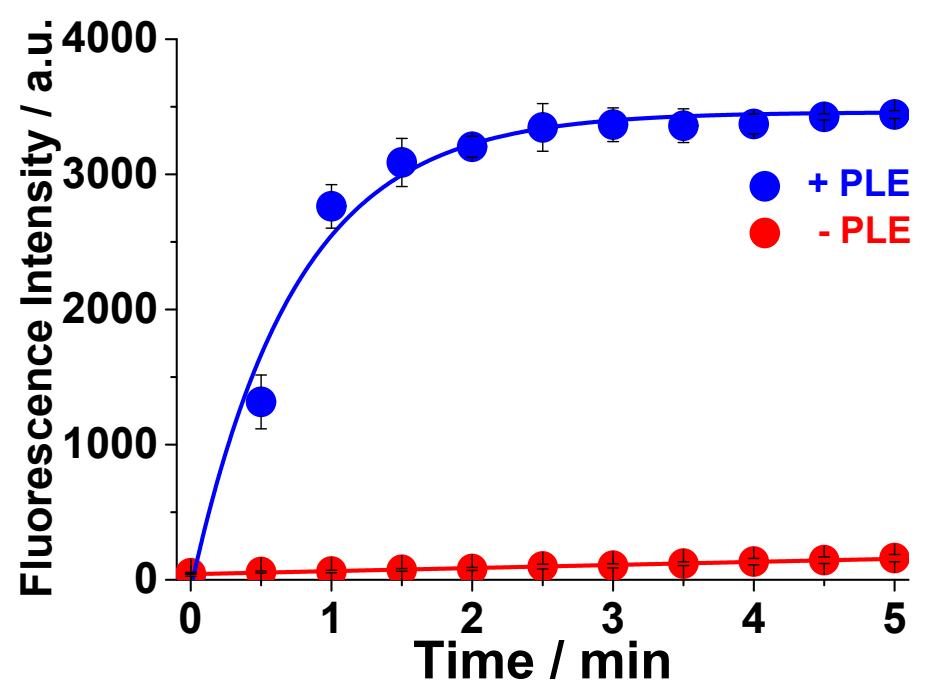

Figure S28. Fluorescence response of 4-MUB in the absence (red) and presence of PLE (0.5 U/mL, blue) for different time periods $(0-5 \mathrm{~min})$ in phosphate buffer $(10 \mathrm{mM}, \mathrm{pH}=7.4,1 \% \mathrm{DMSO})$ at $25^{\circ} \mathrm{C}$. The spectra were obtained every $30 \mathrm{sec}(0-5 \mathrm{~min})$ after the addition of PLE to 4-MUB, and relative fluorescence intensity at 451 $\mathrm{nm}$ was obtained. Excited at $300 \mathrm{~nm}$. [4-MUB] $=10 \mu \mathrm{M}$. 
Fluorescence responses of $\boldsymbol{B}$-MC4 toward various analytes
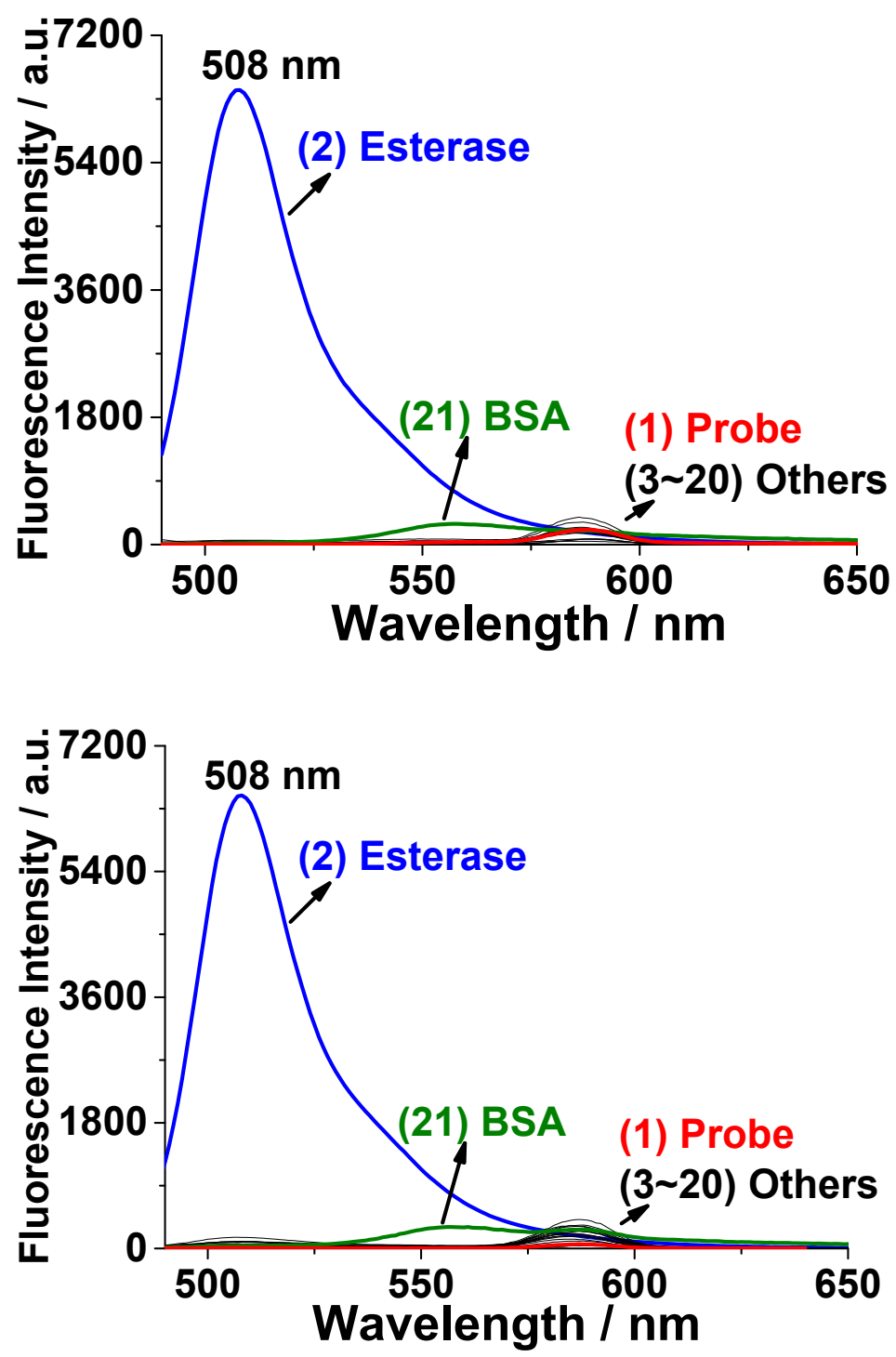

Figure S29. Fluorescence emission spectra of B-MC4 $(10 \mu \mathrm{M})$ upon incubation with various analytes in phosphate buffer solution (10 mM, pH 7.4, 1\% DMSO) at $25{ }^{\circ} \mathrm{C}$. The spectra were obtained 5 min (top) and 30 min (bottom) after the addition of each analyte, respectively, and compared with the one obtained upon addition of esterase. (1) B-MC4 only as a control, (2) porcine liver esterase, (3) lipase, (4) trypsin, (5) alkaline phosphatase (6) lysozyme, (7) $\mathrm{HOCl} \mathrm{OCl}^{-}$, (8) $\mathrm{H}_{2} \mathrm{O}_{2}$, (9) $\mathrm{KO}_{2}$, (10) $\mathrm{NaSH}$, (11) glutathione, (12) homocysteine, (13) dithiothreitol, (14) cysteine, (15) lysine, (16) arginine, (17) histidine, (18) tryptophan, (19) serine, (20) glucose, (21) BSA. Excited at $460 \mathrm{~nm}$. [2] [6] = $30 \mu \mathrm{g} / \mathrm{mL}$; [7] [9] $=0.5 \mathrm{mM} ;[10] \sim[20]=5 \mathrm{mM} ;[21]=330 \mu \mathrm{g} / \mathrm{mL}$. Fluorescence measurements were carried out by monitoring fluorescence emission spectra using a computercontrolled fluorescence micro plate reader. 

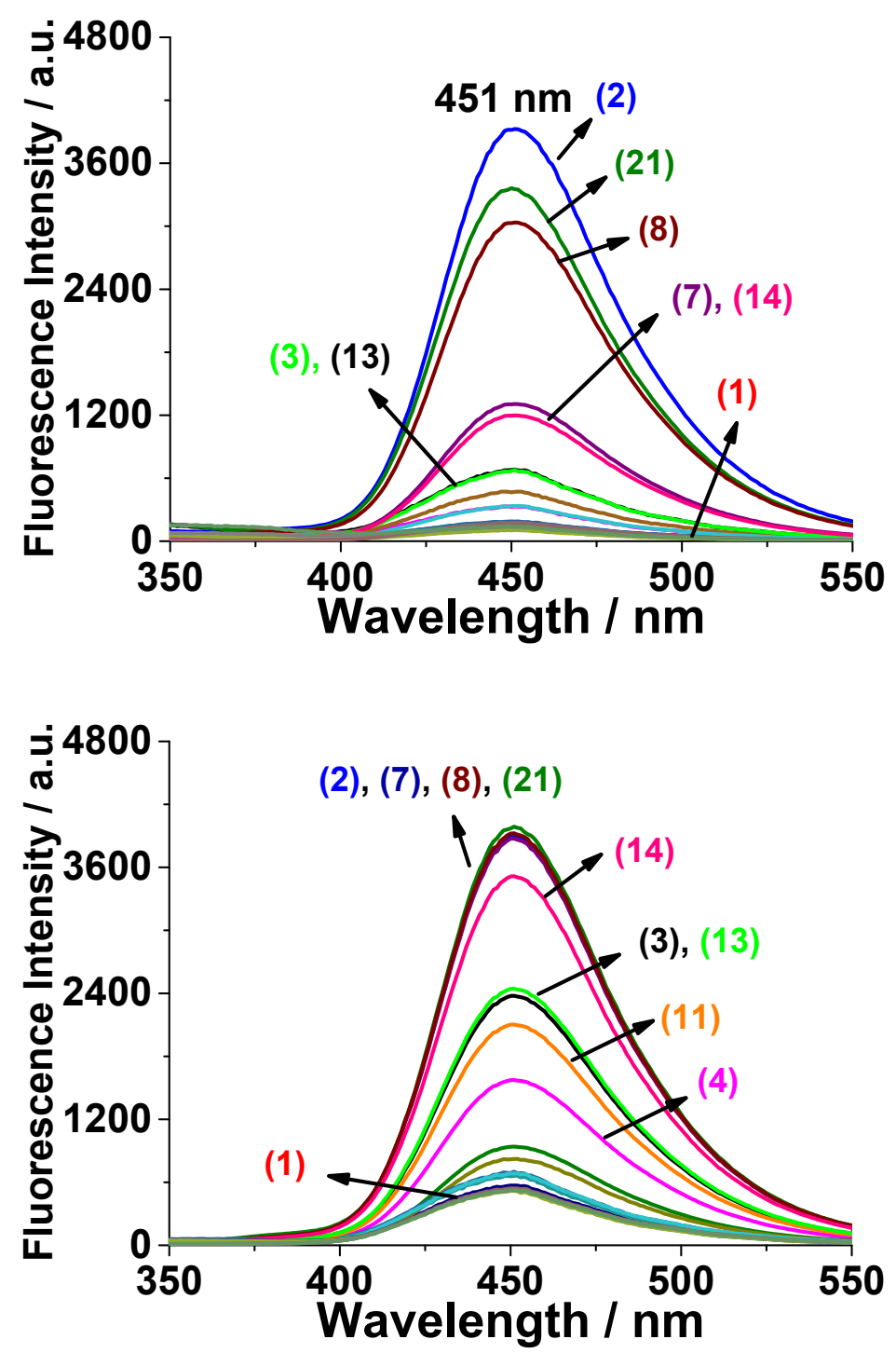

Figure S30. Fluorescence emission spectra of 4-MUB $(10 \mu \mathrm{M})$ upon incubation with various analytes in

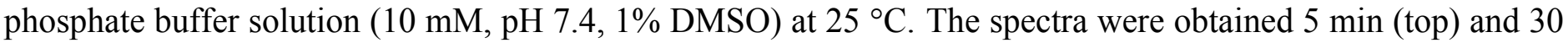
min (bottom) after the addition of each analyte, respectively, and compared with the one obtained upon addition of esterase. (1) 4-MUB only as a control, (2) porcine liver esterase, (3) lipase, (4) trypsin, (5) alkaline phosphatase (6) lysozyme, (7) $\mathrm{HOCl} \mathrm{OCl}^{-}$, (8) $\mathrm{H}_{2} \mathrm{O}_{2}$, (9) $\mathrm{KO}_{2}$, (10) $\mathrm{NaSH}$, (11) glutathione, (12) homocysteine, (13) dithiothreitol, (14) cysteine, (15) lysine, (16) arginine, (17) histidine, (18) tryptophan, (19) serine, (20) glucose, (21) BSA. Excited at $300 \mathrm{~nm}$. [2] [6] = $30 \mu \mathrm{g} / \mathrm{mL}$; [7] [9] = $0.5 \mathrm{mM} ;[10] \sim[20]=5 \mathrm{mM} ;[21]=330 \mu \mathrm{g} / \mathrm{mL}$. Fluorescence measurements were carried out by monitoring fluorescence emission spectra using a computercontrolled fluorescence micro plate reader. 


\section{Kinetic Studies of the Reaction of Probes (B-MC4 and 4-MUB) with Esterase}

To determine the kinetic constants, probe B-MC4 at various concentrations $(0.1-4 \mu \mathrm{M})$ was hydrolyzed by PLE $(0.05 \mathrm{U} / \mathrm{mL})$ in phosphate buffer $(10 \mathrm{mM}, \mathrm{pH} 7.4,1 \%$ DMSO). As standards, the enzymatic reaction of commercially available substrate 4-MUB $(0.25-7.5 \mu \mathrm{M})$ was also measured under the similar conditions. The reaction was monitored by measuring fluorescence change at $508 \mathrm{~nm}$ for probe B-MC4 (excited at $460 \mathrm{~nm}$ ), and at $451 \mathrm{~nm}$ for 4-MUB (excited at $300 \mathrm{~nm}$ ) at $25^{\circ} \mathrm{C}$. The initial velocity was calculated from the slope of the each progress curve. The kinetic parameters such as $K_{\mathrm{m}}, V_{\max }$ and $k_{\text {cat }}$ were determined by Lineweaver-Burk plot and listed in Table S2.

Table S2. Kinetic parameters of probes B-MC4 and 4-MUB

\begin{tabular}{ccccc}
\hline Substrates & $K_{\mathrm{m}}(\mu \mathrm{M})$ & $V_{\max }\left(\mu \mathrm{M} \cdot \mathrm{s}^{-1}\right)$ & $k_{\text {cat }}\left(\mathrm{s}^{-1}\right)$ & $k_{\text {cat }} \mathrm{K}_{\mathrm{m}}\left(\mathrm{M}^{-1} \cdot \mathrm{s}^{-1}\right)$ \\
\hline B-MC4 & 0.96 & 0.037 & 2.11 & $2.20 \times 10^{6}$ \\
4-MUB & 7.07 & 0.071 & 4.01 & $5.70 \times 10^{5}$ \\
\hline
\end{tabular}

(a) Determination of kinetic constants for the reaction of B-MC4 with PLE

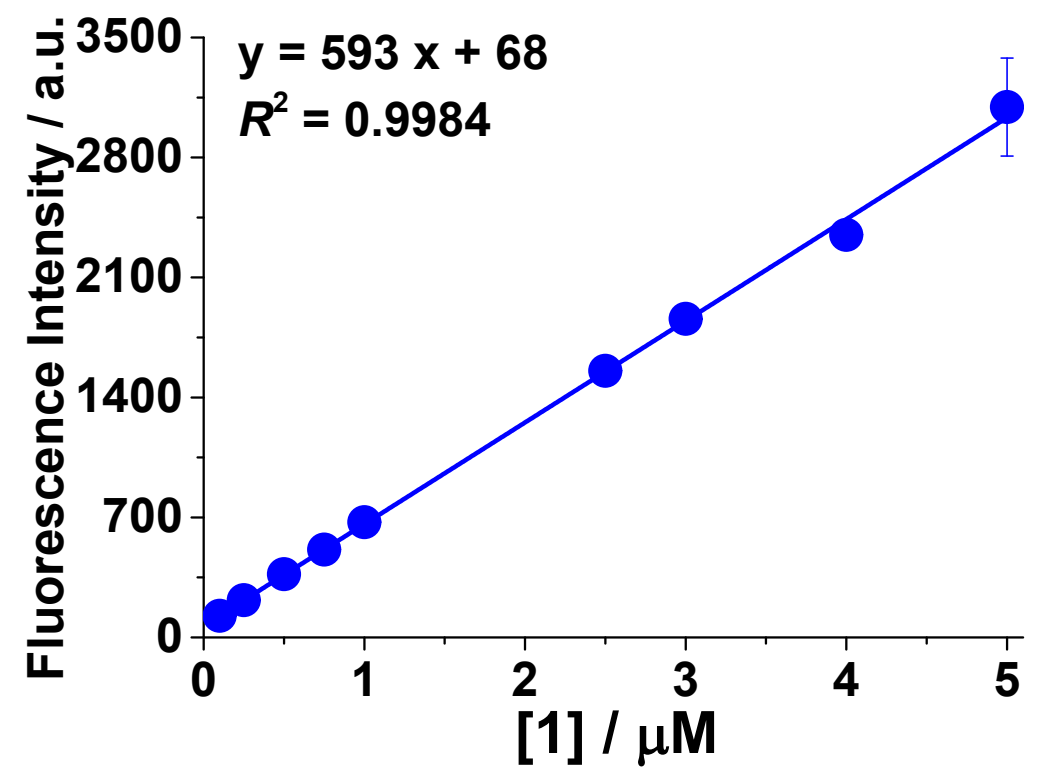

Figure S31. Standard fluorescence curve of the expected hydrolyzed product 1 at different concentrations $(0.5-$ $5 \mu \mathrm{M})$ in phosphate buffer $(10 \mathrm{mM}, \mathrm{pH} 7.4,1 \% \mathrm{DMSO})$ at $25^{\circ} \mathrm{C}$. Fluorescence intensity was measured at 510 $\mathrm{nm}$. Excited at $460 \mathrm{~nm}$. 


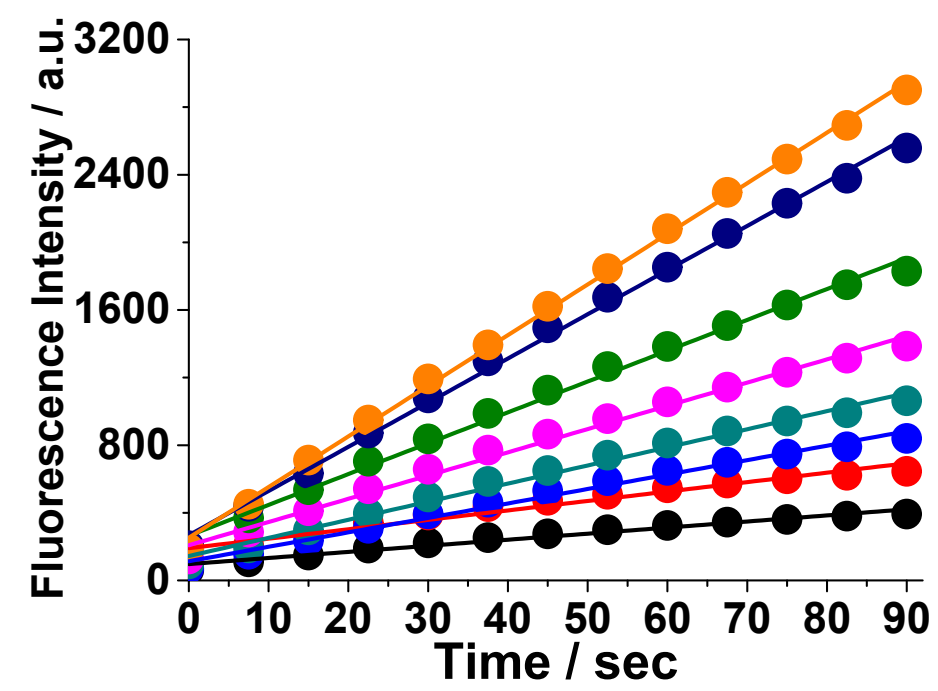

Figure S32. Progress curves of hydrolysis of probe B-MC4 at a series of concentrations $(0.1-4 \mu \mathrm{M})$ upon incubation with PLE $(0.05 \mathrm{U} / \mathrm{mL})$. The emission spectra were obtained every $10 \mathrm{sec}(0-90 \mathrm{sec})$ after the addition of PLE to B-MC4 in phosphate buffer $(10 \mathrm{mM}, \mathrm{pH} 7.4,1 \% \mathrm{DMSO})$ at $25{ }^{\circ} \mathrm{C}$. Fluorescence intensity at $508 \mathrm{~nm}$ was recorded. Excited at $460 \mathrm{~nm}$.
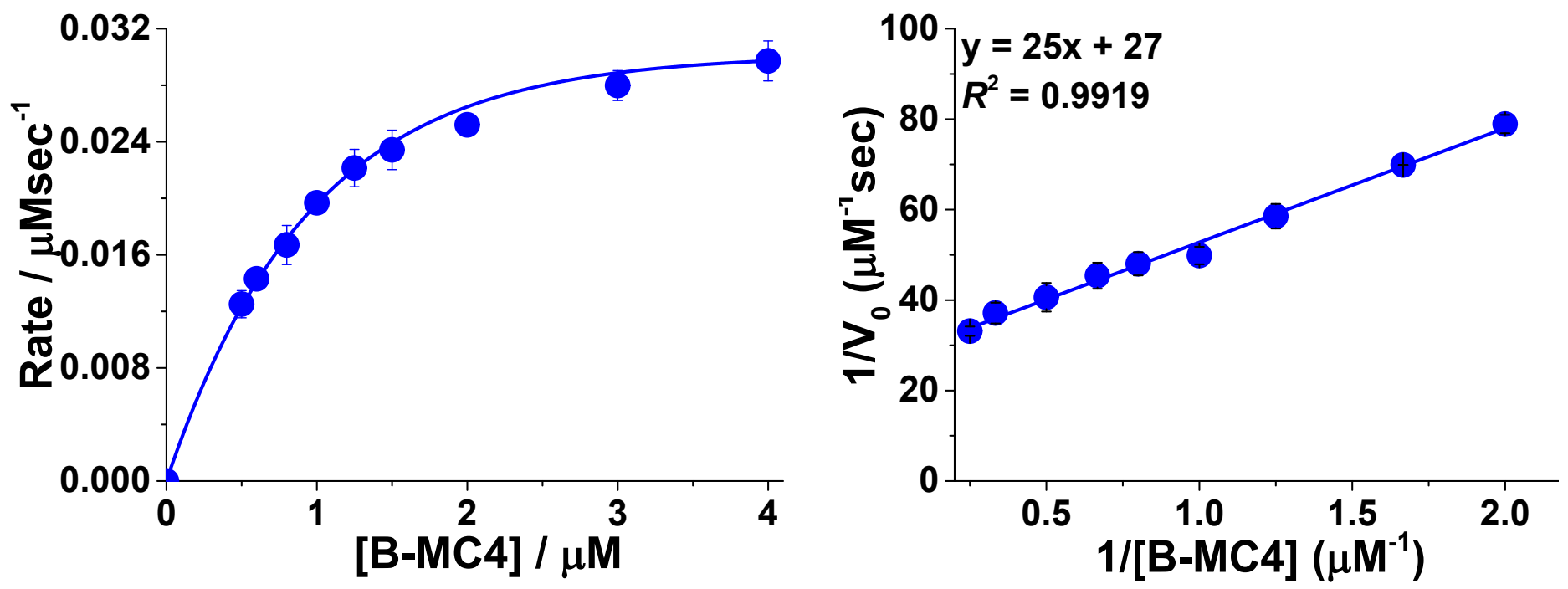

Figure S33. (left) A plot of the initial velocity $\left(v_{0}\right)$ of the hydrolysis of B-MC4 by PLE $(0.05 \mathrm{U} / \mathrm{mL})$ versus concentration of B-MC4. (right) A double reciprocal (Lineweaver-Burk) plot. 


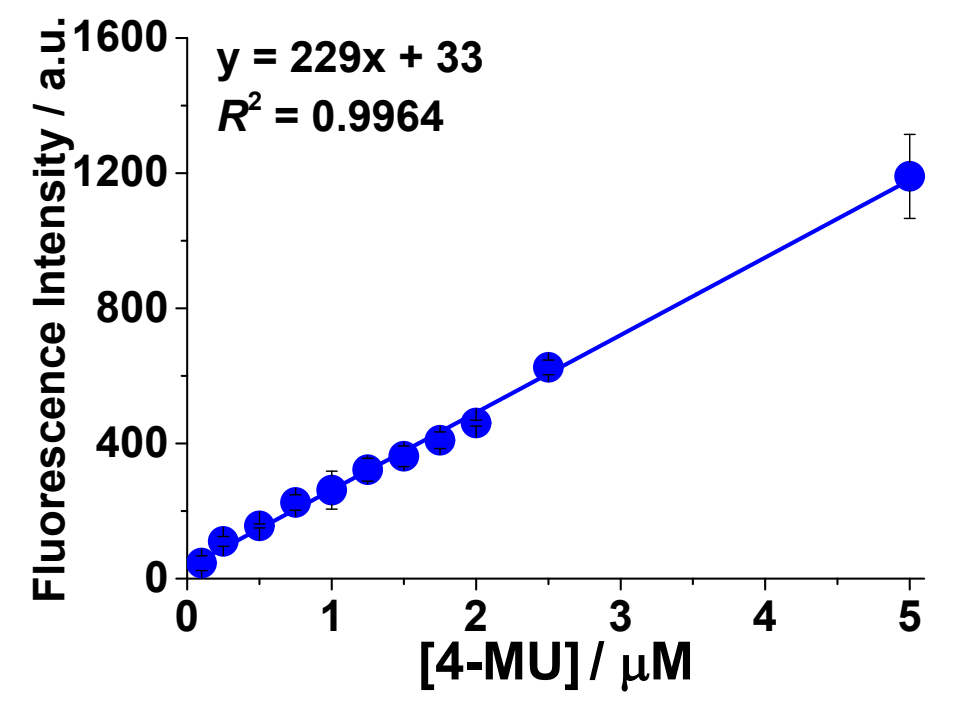

Figure S34. Standard fluorescence curve of the expected hydrolyzed product 4-MU at different concentrations $(0.1-5 \mu \mathrm{M})$ in phosphate buffer $(10 \mathrm{mM}, \mathrm{pH} 7.4,1 \% \mathrm{DMSO})$ at $25^{\circ} \mathrm{C}$. Fluorescence intensity was measured at $451 \mathrm{~nm}$. Excited at $300 \mathrm{~nm}$.

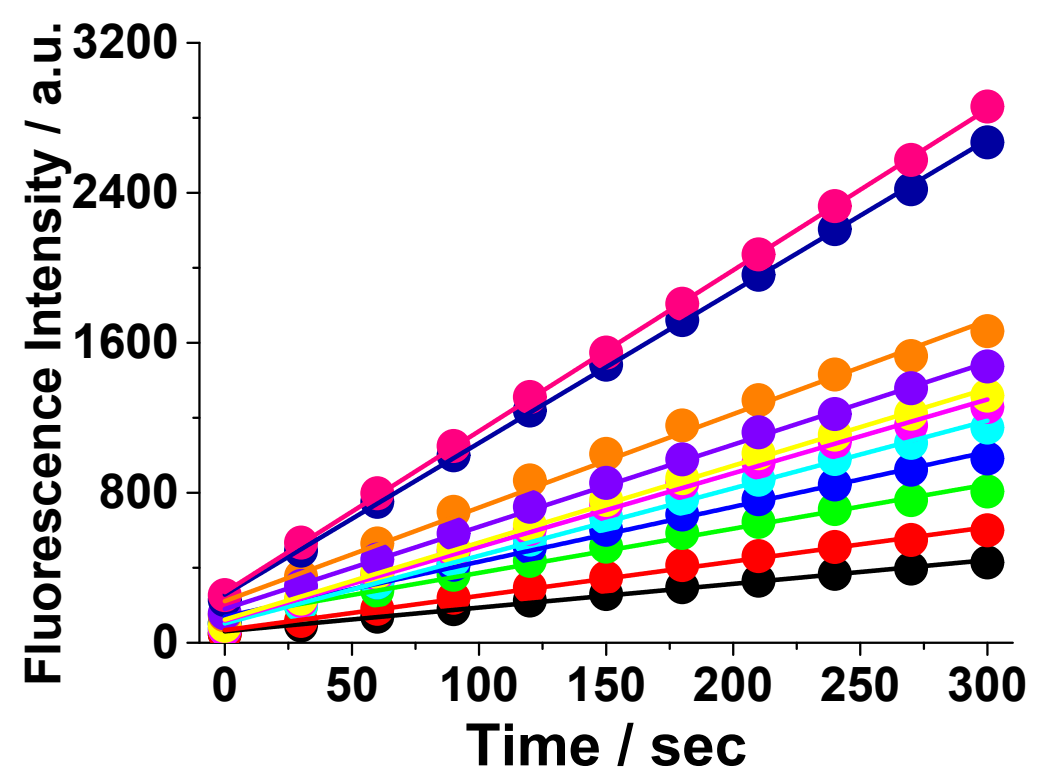

Figure S35. Progress curves of hydrolysis of probe 4-MUB at a series of concentrations $(0.25-7.5 \mu \mathrm{M})$ upon incubation with PLE $(0.05 \mathrm{U} / \mathrm{mL})$. The emission spectra were obtained every $30 \mathrm{sec}(0-300 \mathrm{sec})$ after the addition of PLE to 4-MUB in phosphate buffer $(10 \mathrm{mM}, \mathrm{pH} 7.4,1 \% \mathrm{DMSO})$ at $25^{\circ} \mathrm{C}$. Fluorescence intensity at $451 \mathrm{~nm}$ was recorded. Excited at $300 \mathrm{~nm}$. 

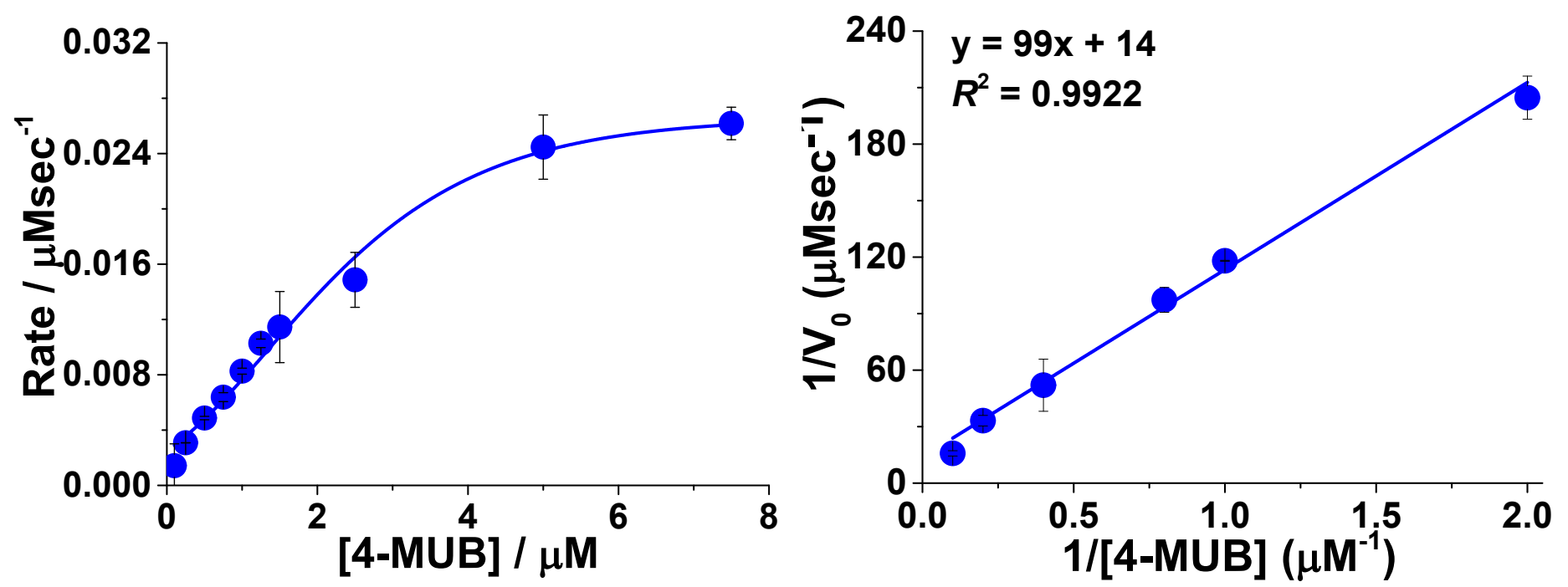

Figure S36. (left) A plot of the initial velocity $\left(v_{0}\right)$ of the hydrolysis of 4-MUB by PLE $(0.05 \mathrm{U} / \mathrm{mL})$ versus concentration of 4-MUB. (right) A double reciprocal (Lineweaver-Burk) plot. 


\section{Inhibition Assay}

For inhibition assay of enzyme activity, the final concentrations of B-MC4 and PLE were fixed to $10 \mu \mathrm{M}$ and $0.5 \mathrm{U} / \mathrm{mL}$, respectively. Two esterase inhibitors, 4-(2-aminoethyl)benzenesulfonyl fluoride hydrochloride (AEBSF) and sodium fluoride $(\mathrm{NaF})$ were dissolved in phosphate buffer $(10 \mathrm{mM}, \mathrm{pH} 7.4)$ to obtain a stock solution of $0.2 \mathrm{M}(\mathrm{AEBSF})$ and $2 \mathrm{M}(\mathrm{NaF})$, respectively, and diluted with phosphate buffer $(10 \mathrm{mM}, \mathrm{pH} 7.4)$ to achieve various concentrations of inhibitors ${ }^{4-5}([\mathrm{AEBSF}]=0-10 \mathrm{mM}$; $[\mathrm{NaF}]=0-100 \mathrm{mM})$. To $178 \mu \mathrm{L}$ of working solution of phosphate buffer $(10 \mathrm{mM}, \mathrm{pH} 7.4,0.5 \mathrm{U} / \mathrm{mL}$ PLE) was added to a solution of inhibitor (20 $\mu \mathrm{L}$ ), and the mixed solutions were incubated for $30 \mathrm{~min}$ at $25^{\circ} \mathrm{C}$ to inhibit enzyme activity. To the inhibitortreated working solution was then added $2 \mu \mathrm{L}$ of B-MC4 (dissolved in DMSO). Fluorescence spectra were recorded every $1 \mathrm{~min}$ for $10 \mathrm{~min}$ at $25^{\circ} \mathrm{C}$ after the addition of $\mathbf{B}-\mathbf{M C} 4$ to each solution. $\mathrm{IC}_{50}$ value (the inhibitor concentration required to reduce enzyme activity by 50\%) was obtained from the plot of relative activity versus inhibitor concentration at $10 \mathrm{~min}$ time point. Fluorescence measurements were carried out by monitoring fluorescence emission spectra using a computer-controlled fluorescence micro plate reader.

\section{(a) Inhibition by 4-(2-aminoethyl)benzenesulfonyl fluoride hydrochloride (AEBSF)}
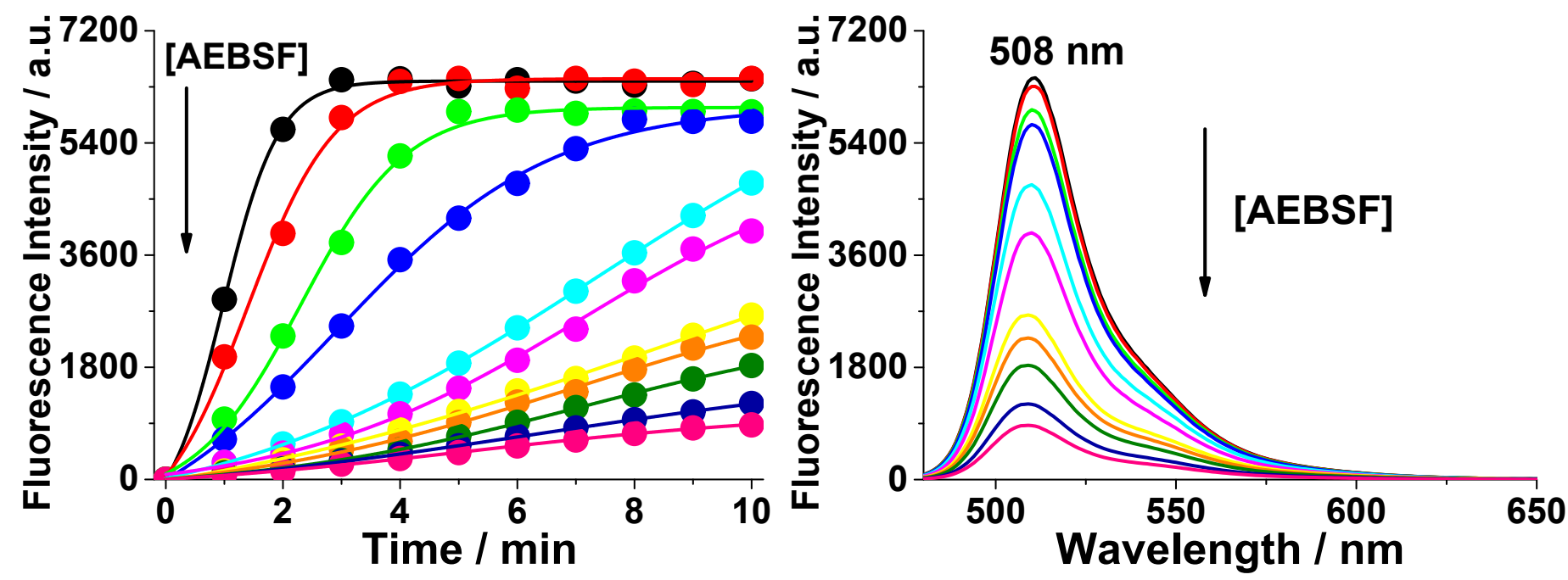

Figure S37. Inhibition assay of PLE activity using B-MC4 $(10 \mu \mathrm{M})$ in phosphate buffer $(10 \mathrm{mM}, \mathrm{pH} 7.4,1 \%$ DMSO) at $25^{\circ} \mathrm{C}$. (left) Kinetic profiles $(0-10 \mathrm{~min})$ of B-MC4 $(10 \mu \mathrm{M})$ after addition of the PLE $(0.5 \mathrm{U} / \mathrm{mL})$ solution, which was pretreated with AEBSF at different concentrations (from top to bottom: 0, 0.010, 0.05, 0.1, $0.2,0.25,0.75,1.0,2.5,5$, and $10.0 \mathrm{mM}$ ) for $30 \mathrm{~min}$ at $25^{\circ} \mathrm{C}$. Fluorescence intensity at $508 \mathrm{~nm}$ was recorded every 1 min after each treatment. Excited at $460 \mathrm{~nm}$. (right) Fluorescence emission spectra of the each assay solution at 10 min time point. 

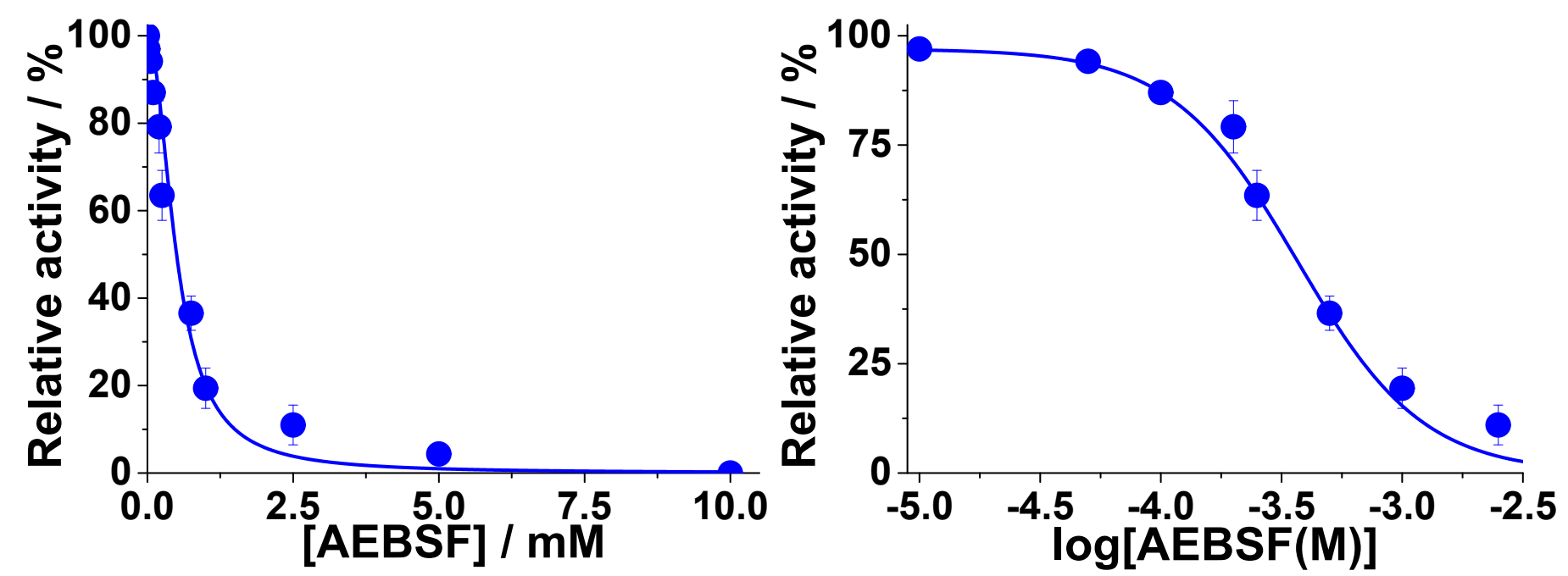

Figure S38. Inhibition assay of PLE activity using B-MC4 $(10 \mu \mathrm{M})$ in phosphate buffer $(10 \mathrm{mM}, \mathrm{pH} 7.4,1 \%$ DMSO, $\left.25{ }^{\circ} \mathrm{C}\right)$. Relative activation of fluorescence at $508 \mathrm{~nm}$ versus concentration of AEBSF $(0-10 \mathrm{mM})$ at 10 min time point. $[\mathrm{PLE}]=0.5 \mathrm{U} / \mathrm{mL}$. $\mathrm{IC}_{50}$ value was determined as $0.39 \pm 0.03 \mathrm{mM}$. 

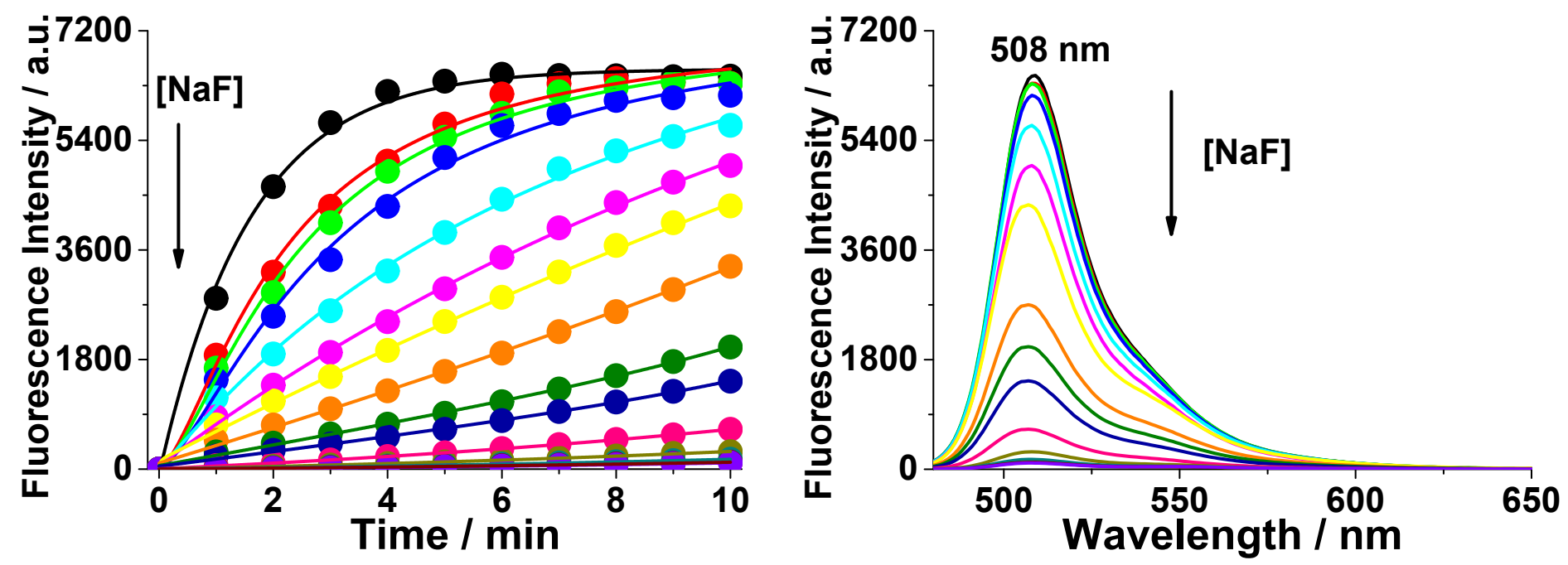

Figure S39. Inhibition assay of PLE activity using B-MC4 $(10 \mu \mathrm{M})$ in phosphate buffer $(10 \mathrm{mM}, \mathrm{pH} 7.4,1 \%$ DMSO) at $25^{\circ} \mathrm{C}$. (left) Kinetic profiles $(0-10 \mathrm{~min})$ of B-MC4 $(10 \mu \mathrm{M})$ after addition of the PLE $(0.5 \mathrm{U} / \mathrm{mL})$ solution, which was pretreated with $\mathrm{NaF}$ at different concentrations (from top to bottom: 0, 0.05, 0.1, 0.25, 0.50, $0.75,1.00,2.50,5.00,7.50,10.00,25.00,50.00,75.00$, and $100.00 \mathrm{mM}$ ) for $30 \mathrm{~min}$ at $25^{\circ} \mathrm{C}$. Fluorescence intensity at $508 \mathrm{~nm}$ was recorded every $1 \mathrm{~min}$ after each treatment. Excited at $460 \mathrm{~nm}$. (right) Fluorescence emission spectra of the corresponding solutions at $10 \mathrm{~min}$ time point.
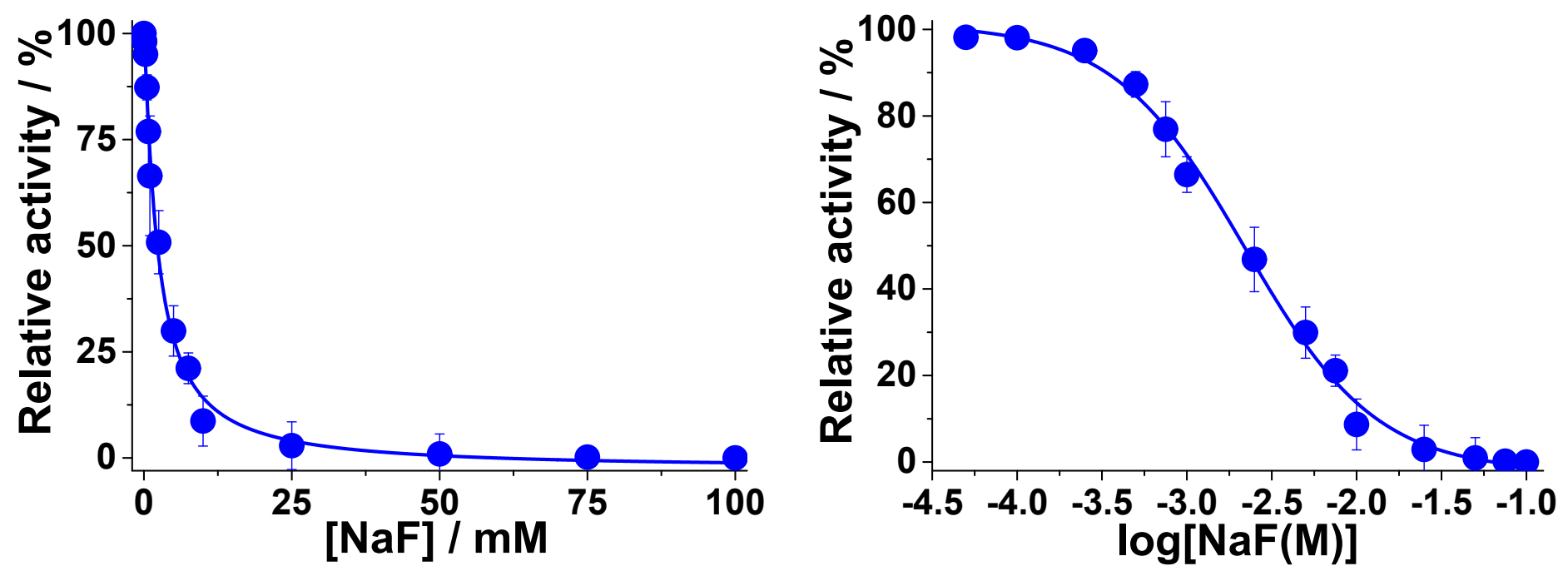

Figure S40. Inhibition assay of PLE activity using B-MC4 $(10 \mu \mathrm{M})$ in phosphate buffer $(10 \mathrm{mM}, \mathrm{pH} 7.4,1 \%$ DMSO, $\left.25{ }^{\circ} \mathrm{C}\right)$. Relative activation of fluorescence at $508 \mathrm{~nm}$ versus concentration of $\mathrm{NaF}(0-100 \mathrm{mM})$ at 10 min time point. $[\mathrm{PLE}]=0.5 \mathrm{U} / \mathrm{mL}$. $\mathrm{IC}_{50}$ value was determined as $2.6 \pm 0.2 \mathrm{mM}$. 
7. DLS analysis of B-MC4 before and after incubation with PLE

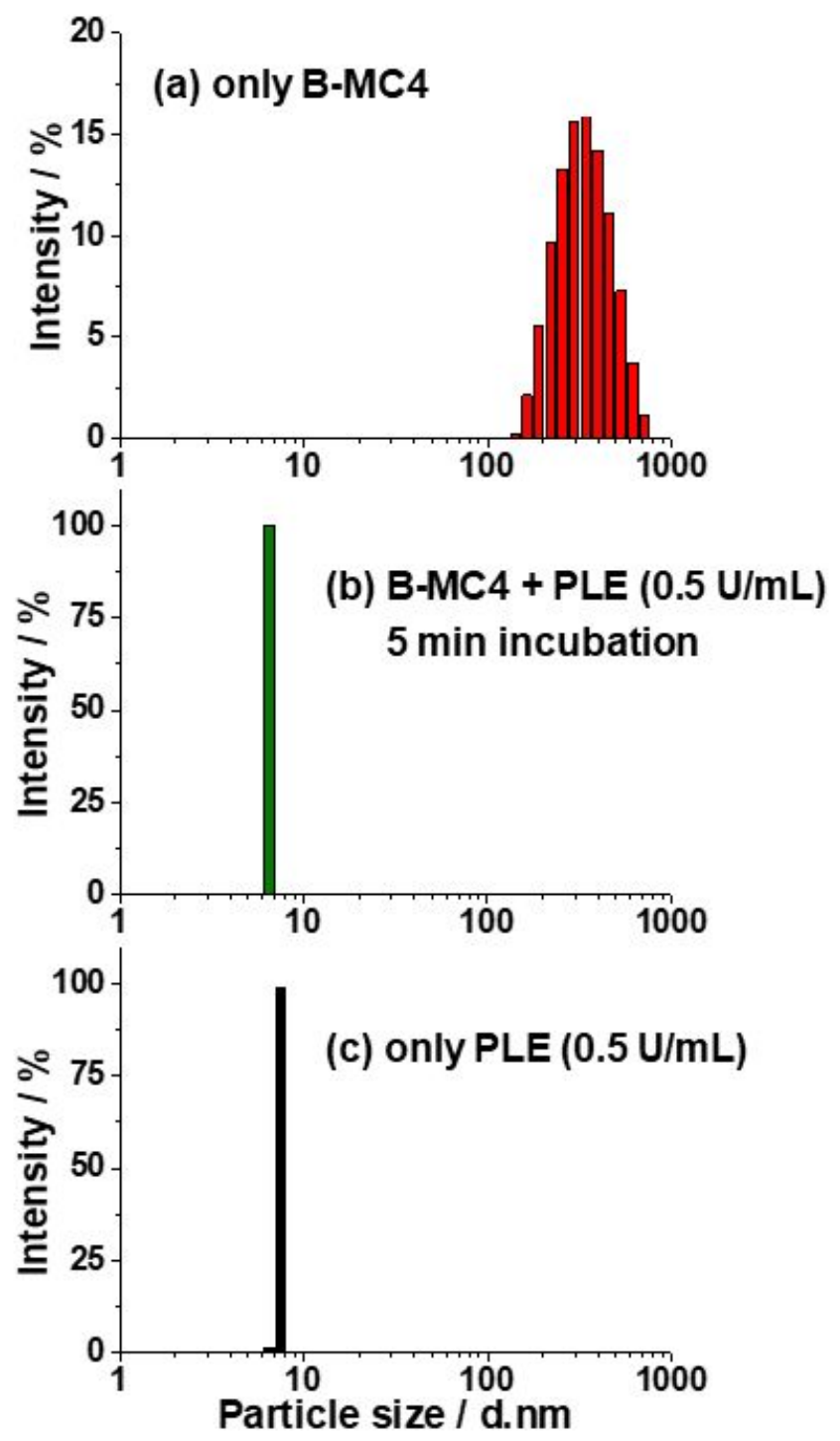

Figure S41. (a) Dynamic light scattering (DLS) analysis of B-MC4 aggregates before (a) and after (b) the treatment with PLE for $5 \mathrm{~min}$, and PLE only (c). All data were obtained in phosphate buffer $(10 \mathrm{mM}, \mathrm{pH} \mathrm{7.4,1 \%}$ DMSO) at $25^{\circ} \mathrm{C}$. [B-MC4] $=10 \mu \mathrm{M}$. [PLE $]=0.5 \mathrm{U} / \mathrm{mL}$. 


\section{Application for the Detection of Moraxella catarrhalis}

\section{(a) Bacterial strains and microbial culture}

Moraxella catarrhalis (DSM 9143) and Salmonella bongori (DSM 13772) were purchased from Deutsche Sammlung Mikroorganismen (DSM), Staphylococcus aureus (ATCC 23235), Listeria monocytogenes (ATCC 19114), and Escherichia coli O157:H7 (ATCC 43895) were obtained from American Type Culture Collection (ATCC). Citrobacter freundii (KCTC 2509) was provided from the Korean Collection for Type Cultures (KCTC).

Staphylococcus aureus, Listeria monocytogenes, and Escherichia coli 0157:H7 were maintained in tryptic soy broth (TSB, Difco, Sparks, MD, USA) at $-80^{\circ} \mathrm{C}$, and Moraxella catarrhalis, C. freundii and Salmonella bongori were maintained in Luria-Bertani broth (LB, Sigma-Aldrich, St. Louis, MO, USA) at $-80^{\circ} \mathrm{C}$, respectively. Both broths contain 20\% glycerol (Sigma-Aldrich, St. Louis, MO, USA).

For culture, a $10 \mu \mathrm{L}$ of each thawed stock culture was inoculated into either $10 \mathrm{~mL}$ of TSB (for $S$. aureus, $L$. monocytogenes and E. coli O157: $\mathrm{H} 7$ ) or $10 \mathrm{~mL}$ of LB broth (for M. catarrhalis and C. freundii), and incubated at $35^{\circ} \mathrm{C}$ with shaking on a rotary shaker (VS-8480SR, Vision, Korea) at $140 \mathrm{rpm}$ for $24 \mathrm{~h}$. After incubation, each bacterial suspension was prepared following serial dilution in phosphate buffer $(10 \mathrm{mM}, \mathrm{pH} 7.4)$ to give bacterial concentrations ranging from $10^{1}$ to $10^{10} \mathrm{CFU} / \mathrm{mL}\left(10^{1}\right.$ to $10^{6} \mathrm{CFU} / \mathrm{mL}$ for M. catarrhalis $)$.

\section{(b) Sensory responses of probes (B-MC4 and 4-MUB) toward various bacteria}

Each bacterial suspension $(100 \mu \mathrm{L})$ was added to probe in phosphate buffer $(10 \mathrm{mM}, \mathrm{pH} 7.4,1 \% \mathrm{DMSO} ; 100$ $\mu \mathrm{L}$ ) at $25^{\circ} \mathrm{C}$, and incubated for the indicated time $(5 \mathrm{~min}, 10 \mathrm{~min}$, or $60 \mathrm{~min}$ ) before recording spectra using a computer-controlled fluorescence plate reader. For taking photographs, a $1000 \mu \mathrm{L}$ of the bacterial solution was incubated with probe in phosphate buffer $(10 \mathrm{mM}, \mathrm{pH} 7.4,1 \% \mathrm{DMSO} ; 1000 \mu \mathrm{L})$. Final concentrations of each probe were $10 \mu \mathrm{M}$ for spectral measurements and $20 \mu \mathrm{M}$ for photographs, respectively. Emission signals were recorded at $508 \mathrm{~nm}\left(\lambda_{\mathrm{ex}}=460 \mathrm{~nm}\right)$ for B-MC4 and 2, and at $451 \mathrm{~nm}\left(\lambda_{\mathrm{ex}}=300 \mathrm{~nm}\right)$ for 4-MUB. 
(c) Colorimetric and fluorogenic responses of B-MC4 toward M. catarrhalis at various concentrations (incubation time $=5$ min and 60 min)
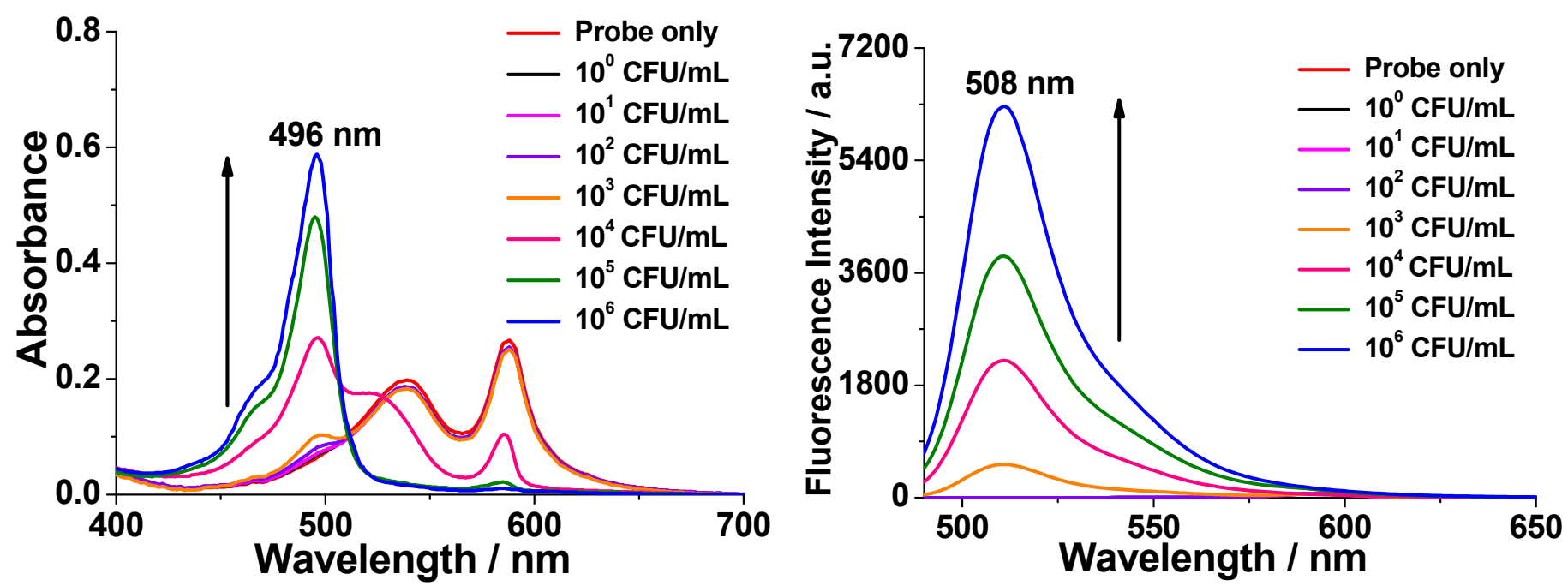

Figure S42. Absorption (left) and fluorescence emission (right) spectra of B-MC4 $(10 \mu \mathrm{M})$ upon incubation with M. catarrhalis at various concentrations $\left(10^{0} \sim 10^{6} \mathrm{CFU} / \mathrm{mL}\right) 25^{\circ} \mathrm{C}$. B-MC4 (DMSO, $2 \mu \mathrm{L}$ ) was added to $10 \mathrm{mM}$

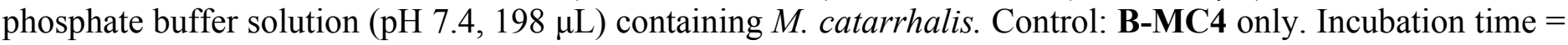
$5 \min . \lambda_{\mathrm{ex}}=460 \mathrm{~nm}$.
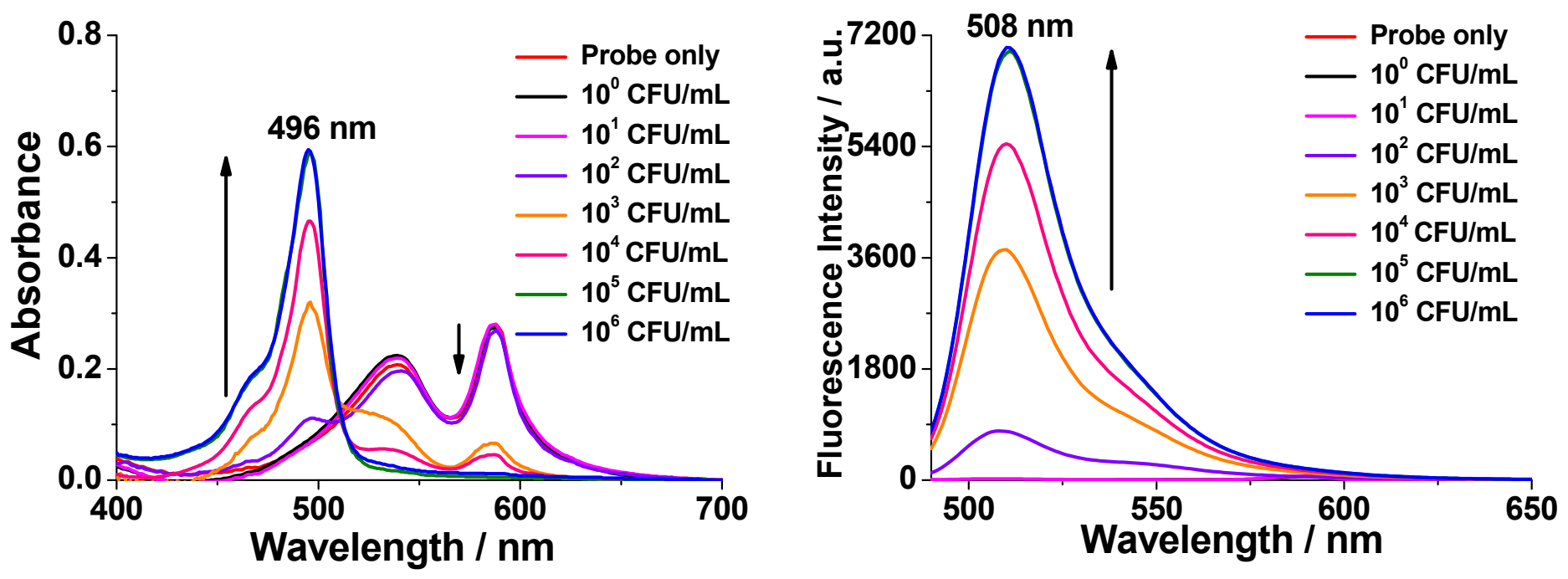

Figure S43. Absorption (left) and fluorescence emission (right) spectra of B-MC4 $(10 \mu \mathrm{M})$ upon incubation with M. catarrhalis at various concentrations $\left(10^{0} \sim 10^{6} \mathrm{CFU} / \mathrm{mL}\right) 25^{\circ} \mathrm{C}$. B-MC4 (DMSO, $2 \mu \mathrm{L}$ ) was added to $10 \mathrm{mM}$ phosphate buffer solution ( $\mathrm{pH} 7.4,198 \mu \mathrm{L}$ ) containing $M$. catarrhalis. Control: B-MC4 only. Incubation time = $60 \min . \lambda_{\text {ex }}=460 \mathrm{~nm}$. 


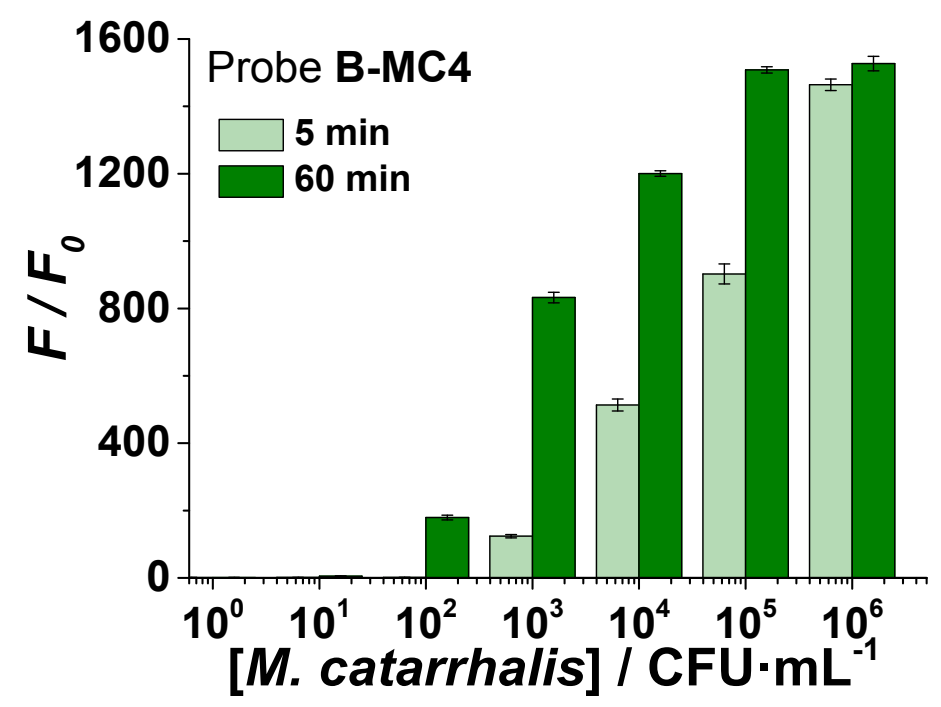

Figure S44. Relative fluorescence intensity $\left(F / F_{0}\right)$ at $508 \mathrm{~nm}$ of B-MC4 $(10 \mu \mathrm{M})$ upon incubation $(5 \mathrm{~min}$, pale green; $60 \mathrm{~min}$, dark green) with $M$. catarrhalis at various concentrations $\left(10^{0} \sim 10^{6} \mathrm{CFU} / \mathrm{mL}\right) . \lambda_{\mathrm{ex}}=460 \mathrm{~nm}$. Error bars indicate \pm standard deviation. All data were obtained in phosphate buffer (10 mM, pH 7.4, 1\% DMSO) at $25{ }^{\circ} \mathrm{C}$. 

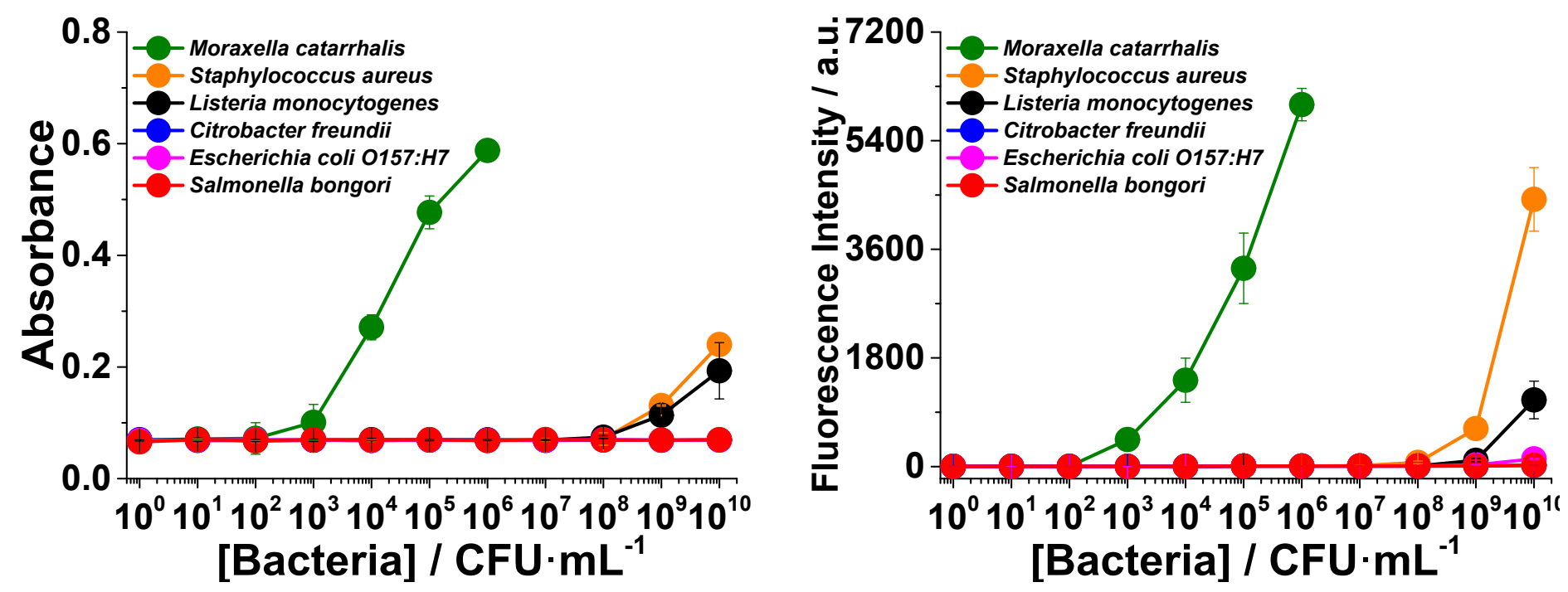

Figure S45. Absorbance at $496 \mathrm{~nm}$ (left) and relative fluorescence intensity at $508 \mathrm{~nm}$ (right) of B-MC4 (10 $\mu \mathrm{M})$ upon $5 \mathrm{~min}$ incubation with each bacterium at various bacterial concentrations $\left(10^{0} \sim 10^{6} \mathrm{CFU} / \mathrm{mL}\right.$ for $M$. catarrhalis; $10^{0} \sim 10^{10} \mathrm{CFU} / \mathrm{mL}$ for others). All data were obtained in phosphate buffer $(10 \mathrm{mM}, \mathrm{pH} 7.4,1 \%$ DMSO) at $25^{\circ} \mathrm{C} . \lambda_{\mathrm{ex}}=460 \mathrm{~nm}$. Error bars indicate \pm standard deviation.

(e) Fluorescence responses of B-MC4 to various bacteria at concentration of $10^{6} \mathrm{CFU} / \mathrm{mL}$ (incubation time $=$ 5 min)
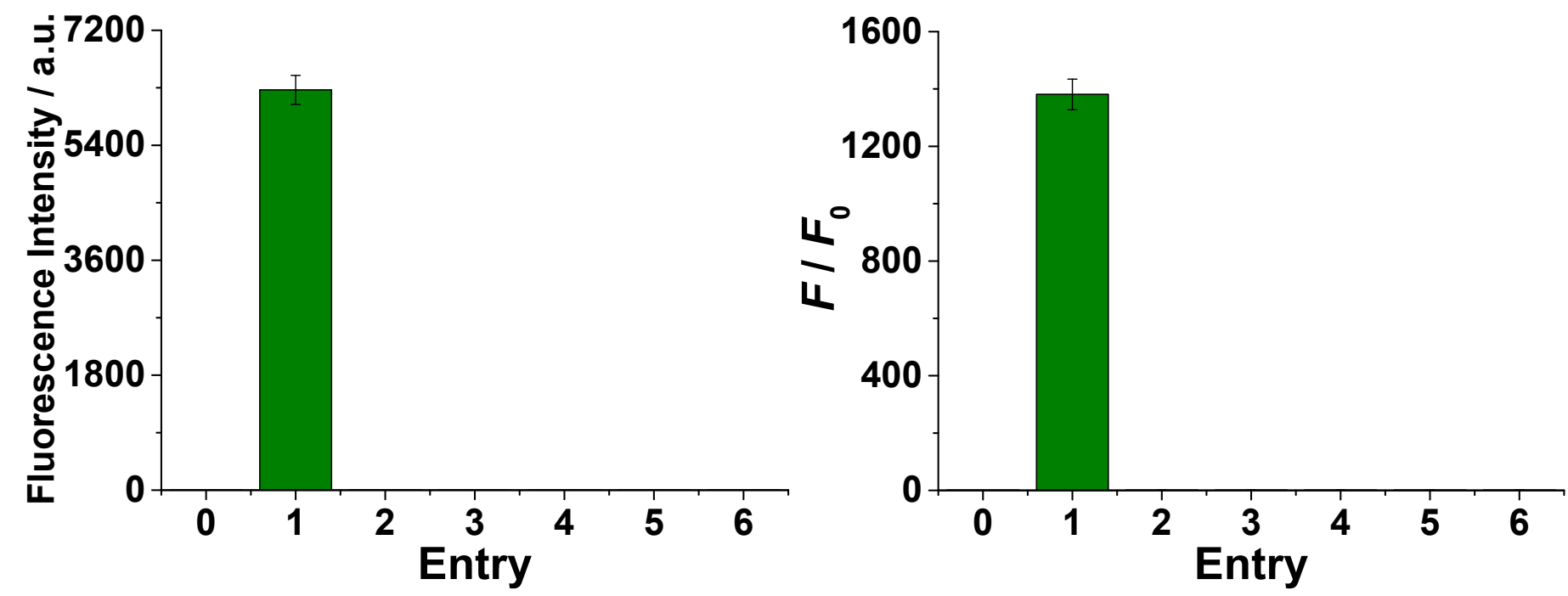

Figure S46. Fluorescence responses of B-MC4 to various bacteria. Relative fluorescence intensity at $508 \mathrm{~nm}$ of B-MC4 $(10 \mu \mathrm{M})$ upon 5 min incubation with each bacterium (bacterial density $=10^{6} \mathrm{CFU} / \mathrm{mL}$ ). $\lambda_{\mathrm{ex}}=460 \mathrm{~nm}$. Error bars indicate \pm standard deviation. All data were obtained in phosphate buffer $(10 \mathrm{mM}, \mathrm{pH} 7.4,1 \%$ DMSO) at $25{ }^{\circ} \mathrm{C}$. (0) Control: B-MC4 only, (1) Moraxella catarrhalis, (2) Staphylococcus aureus, (3) Listeria monocytogenes, (4) Citrobacter freundii, (5) Escherichia coli O157:H7, (6) Salmonella bongori. 
(A) 5 min incubation
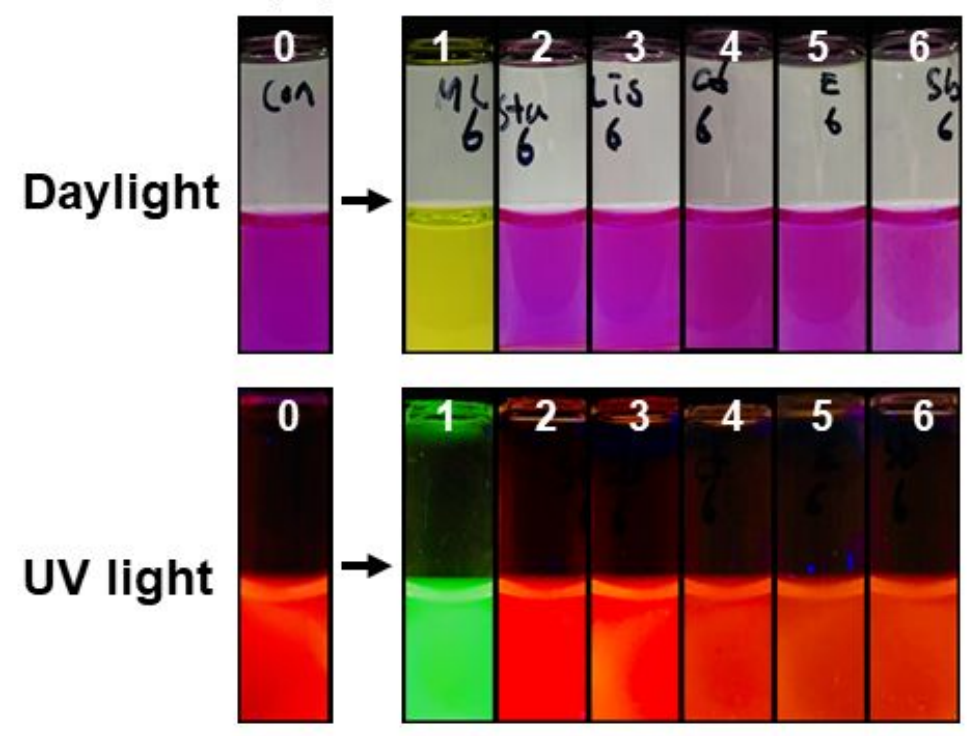

(B) 30 min incubation
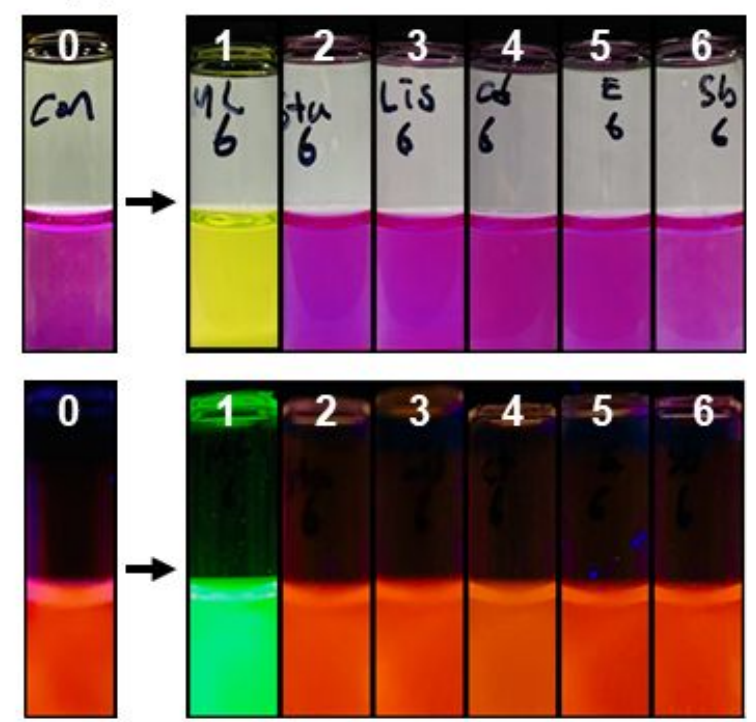

Figure S47. Photographs of B-MC4 (20 $\mu \mathrm{M})$ upon incubation (5 min (A) and $30 \mathrm{~min}$ (B), respectively) with each bacterium $\left(10^{6} \mathrm{CFU} / \mathrm{mL}\right)$ under daylight (top) and $365 \mathrm{~nm} \mathrm{UV}$ irradiation (bottom). All data were obtained in phosphate buffer (10 mM, pH 7.4, 1\% DMSO) at $25^{\circ} \mathrm{C}$. (0) Control: B-MC4 only, (1) Moraxella catarrhalis, (2) Staphylococcus aureus, (3) Listeria monocytogenes, (4) Citrobacter freundii, (5) Escherichia coli O157:H7, (6) Salmonella bongori. 
Photographs: Fluorogenic responses of 4-MUB toward various bacteria (incubation time = 5 min and 30 min)

(A) 5 min incubation

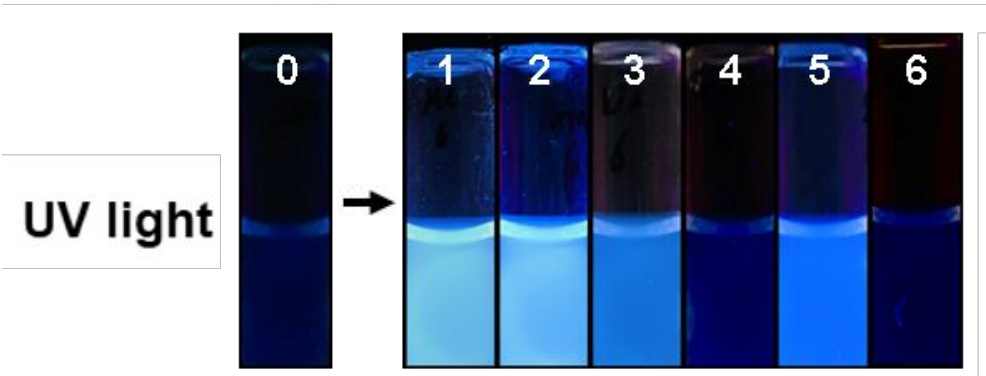

(B) 30 min incubation

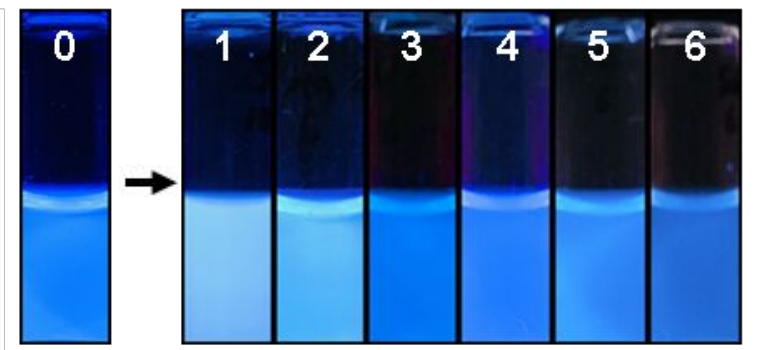

Figure S48. Photographs of 4-MUB $(20 \mu \mathrm{M})$ upon incubation (5 $\mathrm{min}(\mathrm{A})$ and $30 \mathrm{~min}(\mathrm{~B})$, respectively) with each bacterium $\left(10^{6} \mathrm{CFU} / \mathrm{mL}\right)$ under $365 \mathrm{~nm}$ UV irradiation. All data were obtained in phosphate buffer $(10 \mathrm{mM}$, $\mathrm{pH} 7.4,1 \%$ DMSO) at $25{ }^{\circ} \mathrm{C}$. (0) Control: 4-MUB only, (1) Moraxella catarrhalis, (2) Staphylococcus aureus, (3) Listeria monocytogenes, (4) Citrobacter freundii, (5) Escherichia coli O157:H7, (6) Salmonella bongori.

Photographs: Colorimetric and fluorogenic responses of 2 toward various bacteria (incubation time = 30 min)
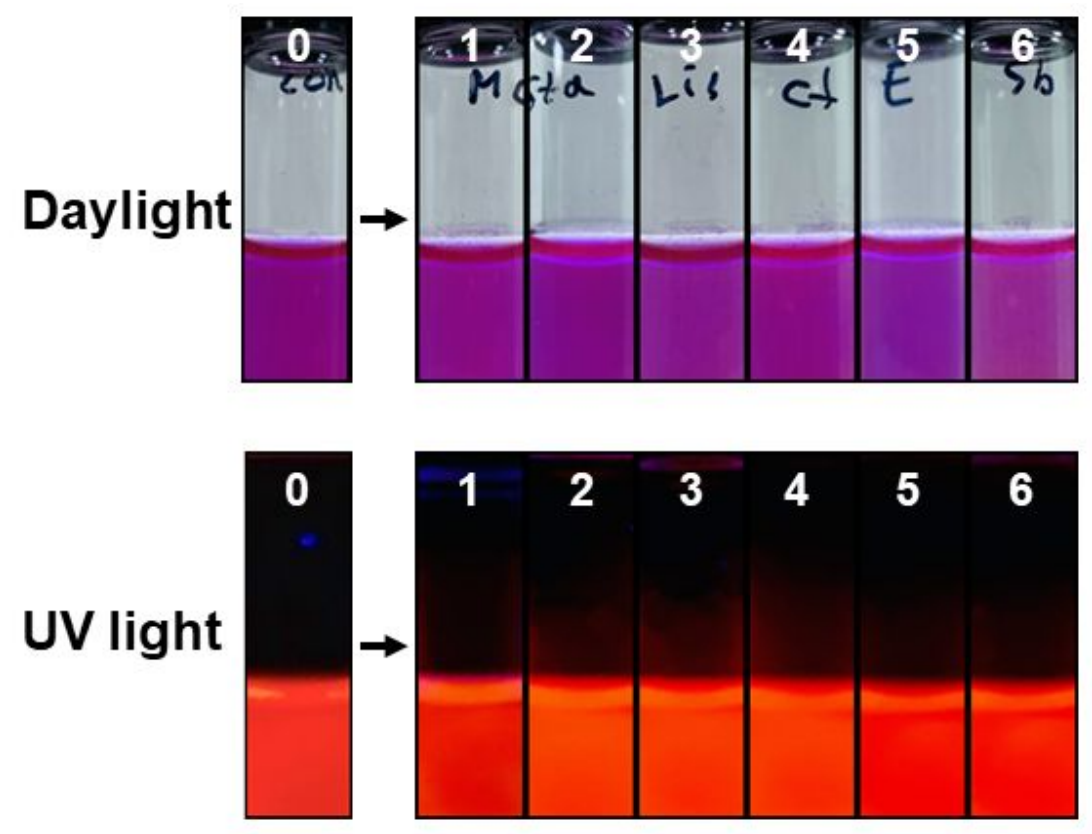

Figure S49. Photographs of $2(20 \mu \mathrm{M})$ upon 30 min incubation with each bacterium $\left(10^{6} \mathrm{CFU} / \mathrm{mL}\right.$ for $M$. catarrhalis; $10^{10} \mathrm{CFU} / \mathrm{mL}$ for others) under daylight (top) and $365 \mathrm{~nm} \mathrm{UV}$ irradiation (bottom). All data were obtained in phosphate buffer (10 mM, pH 7.4, 1\% DMSO) at $25^{\circ} \mathrm{C}$. (0) Control: 2 only, (1) Moraxella catarrhalis, (2) Staphylococcus aureus, (3) Listeria monocytogenes, (4) Citrobacter freundii, (5) Escherichia coli O157:H7, (6) Salmonella bongori. 


\section{(h) Inhibition assay for Moraxella catarrhalis-induced activation of B-MC4}

For inhibition assay of C4-esterase activity expressed in M. catarrhalis, a solution of M. catarrhalis $\left(10^{6} \mathrm{CFU} / \mathrm{mL}\right)$ in phosphate buffer $(10 \mathrm{mM}, \mathrm{pH} 7.4,1 \% \mathrm{DMSO}, 1880 \mu \mathrm{L})$ was pre-incubated with the esterase-specific inhibitor $\mathrm{NaF}(2 \mathrm{M}, 100 \mu \mathrm{L})$ for $30 \mathrm{~min}$ at $25^{\circ} \mathrm{C}$. The solution of M. catarrhalis pre-treated with $\mathrm{NaF}$ was incubated with probe B-MC4 (dissolved in DMSO, $20 \mu \mathrm{L}$ ) for $5 \mathrm{~min}$ at $25^{\circ} \mathrm{C}$. Final concentrations of B-MC4 were $10 \mu \mathrm{M}$ for spectral measurements and $20 \mu \mathrm{M}$ for photographs, respectively. Absorption spectra were obtained on a SCINCO S-3100 spectrophotometer, and fluorescence measurements were recorded on a Hitachi F-7000 fluorescence spectrophotometer.

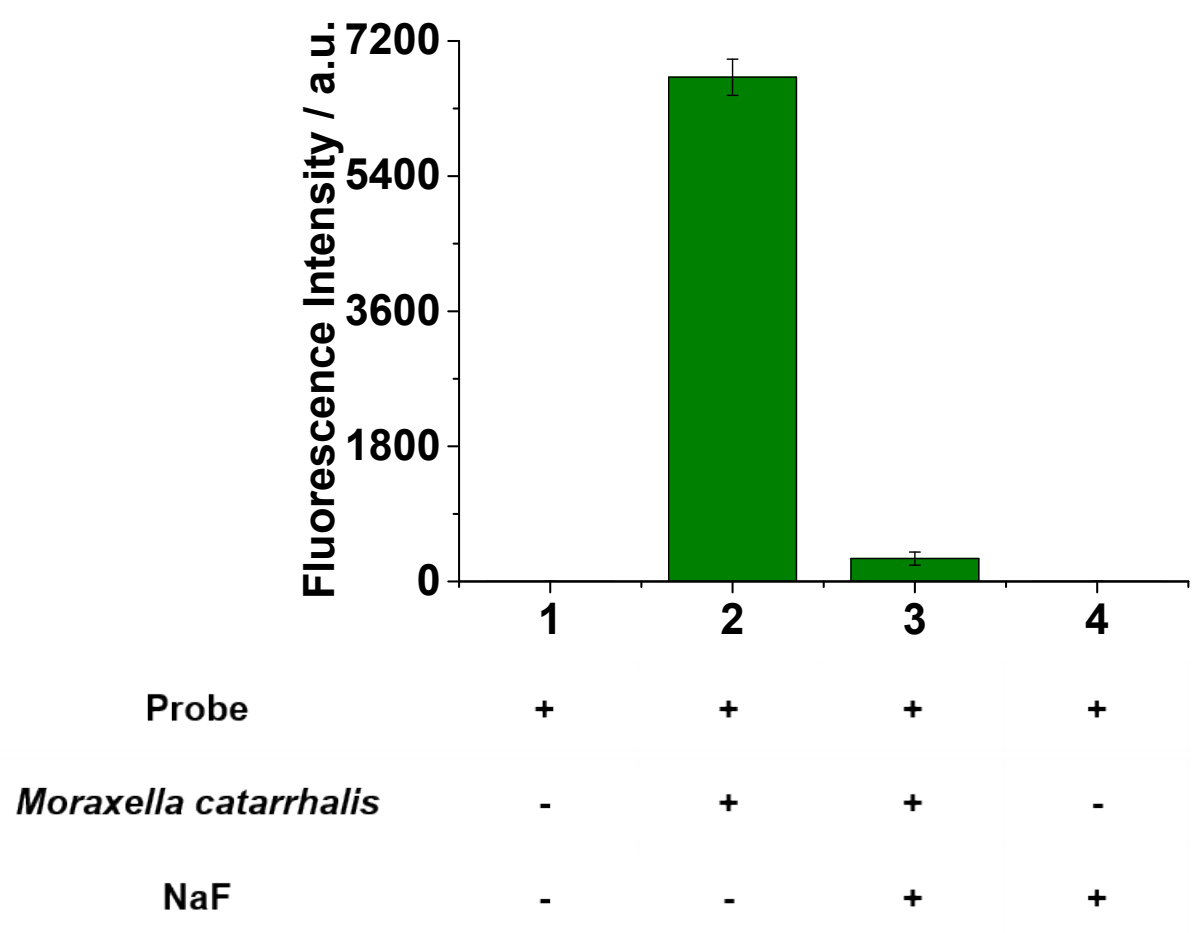

Figure S50. Fluorescence responses of B-MC4 to various conditions. Relative fluorescence intensity at $508 \mathrm{~nm}$ of B-MC4 $(10 \mu \mathrm{M})$ before (1) and after $5 \mathrm{~min}$ incubation with M. catarrhalis in the absence (2) and presence (3) of an inhibitor, NaF. M. catarrhalis $\left(10^{6} \mathrm{CFU} / \mathrm{mL}\right)$ was pre-incubated with inhibitor $\mathrm{NaF}(100 \mathrm{mM})$ for $30 \mathrm{~min}$ at $25{ }^{\circ} \mathrm{C}$ before the addition of B-MC4. Entry 4 indicates no increase in fluorescence at $508 \mathrm{~nm}$ when B-MC4 was incubated only with $\mathrm{NaF}(100 \mathrm{mM})$ for $30 \mathrm{~min} . \lambda_{\text {ex }}=460 \mathrm{~nm}$. All data were obtained in phosphate buffer $(10 \mathrm{mM}, \mathrm{pH} 7.4,1 \% \mathrm{DMSO})$ at $25^{\circ} \mathrm{C}$. Error bars indicate \pm standard deviation. 


\section{9. ${ }^{1} \mathrm{H}-\mathrm{NMR}$ and ${ }^{13} \mathrm{C}-\mathrm{NMR}$ Spectra}

${ }^{1} \mathrm{H}-\mathrm{NMR}$ spectrum of compound 3 in $\mathrm{CDCl}_{3}(500 \mathrm{MHz})$ :<smiles>CCCC(=O)Oc1ccc(CO)cc1</smiles>

3

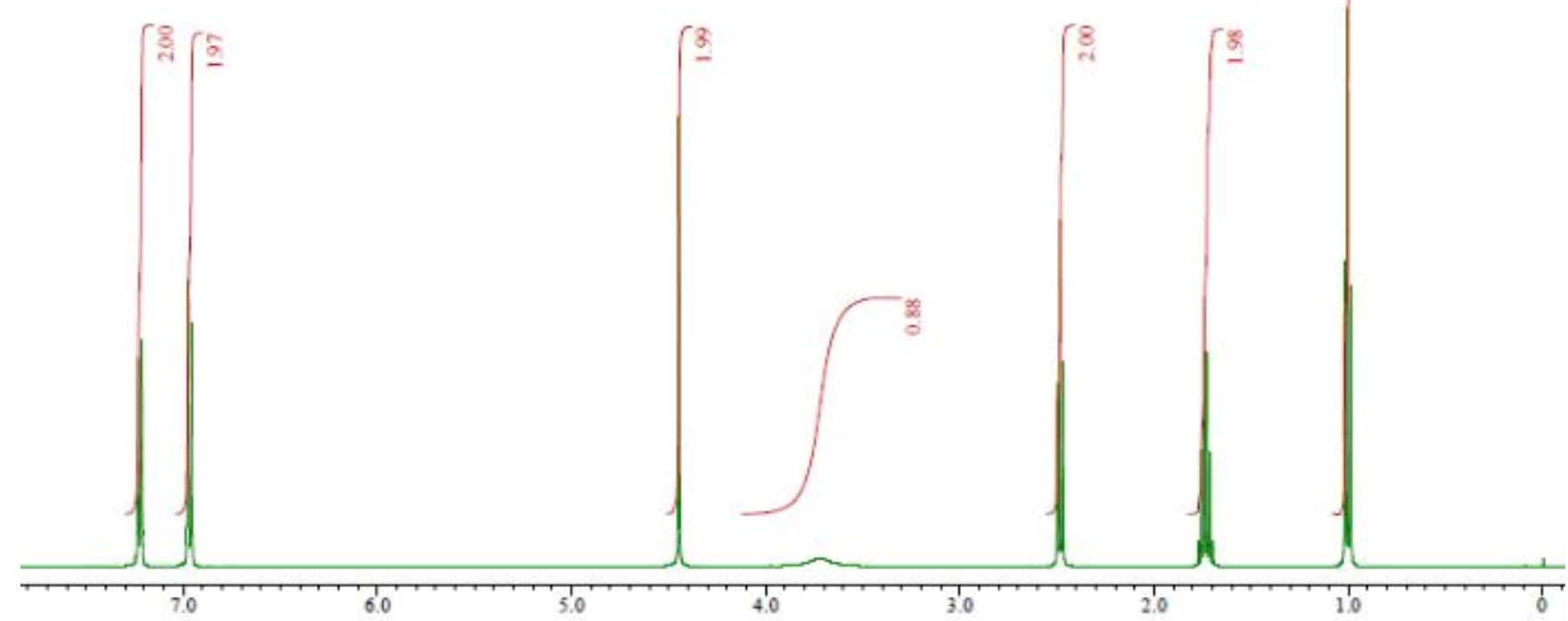

${ }^{1} \mathrm{C}-\mathrm{NMR}$ spectrum of compound 3 in $\mathrm{CDCl}_{3}(125 \mathrm{MHz})$ :

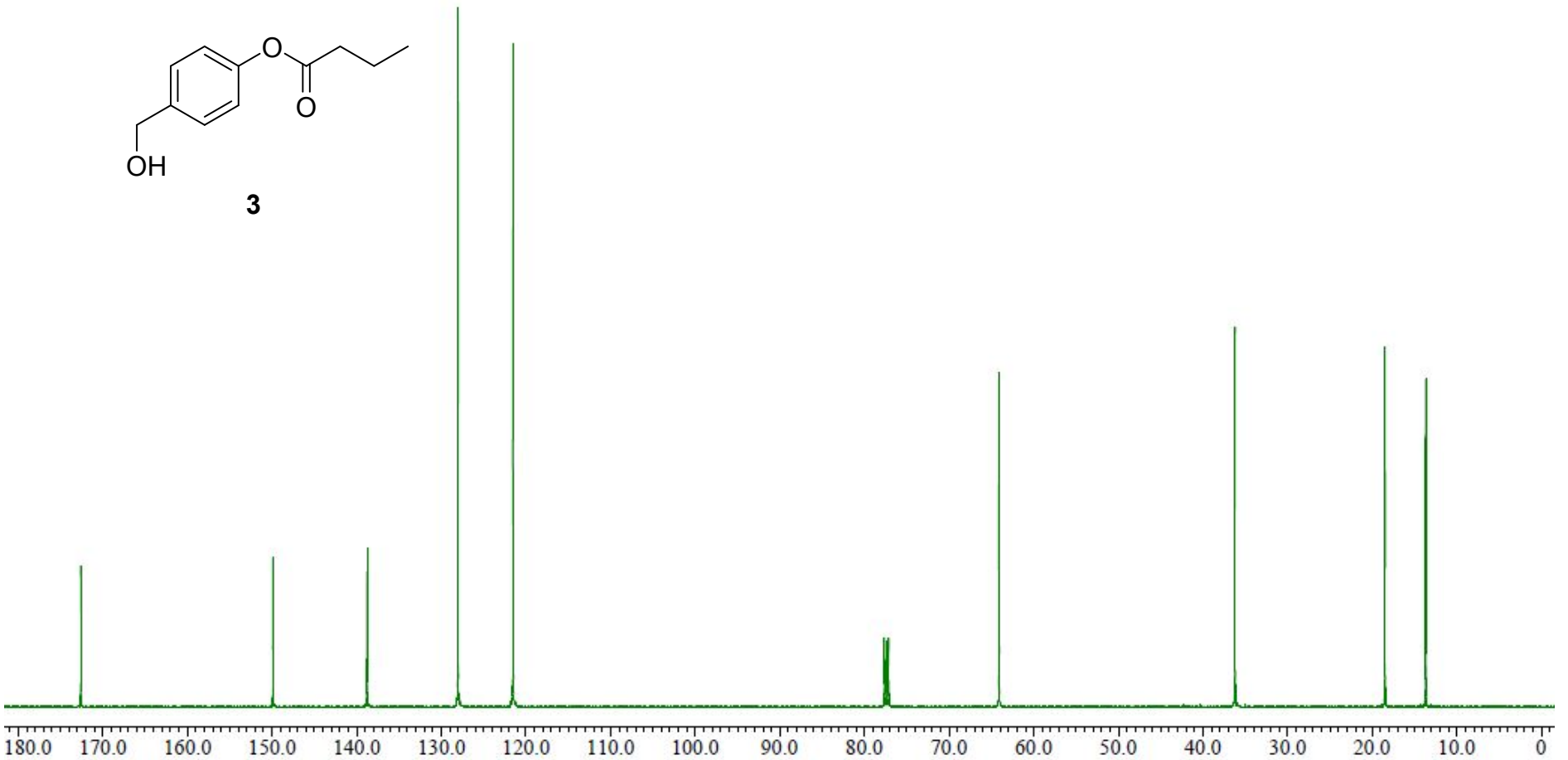


${ }^{1} \mathrm{H}-\mathrm{NMR}$ spectrum of compound 4 in $\mathrm{CDCl}_{3}(400 \mathrm{MHz})$<smiles>CCCC(=O)Oc1ccc(CBr)cc1</smiles>
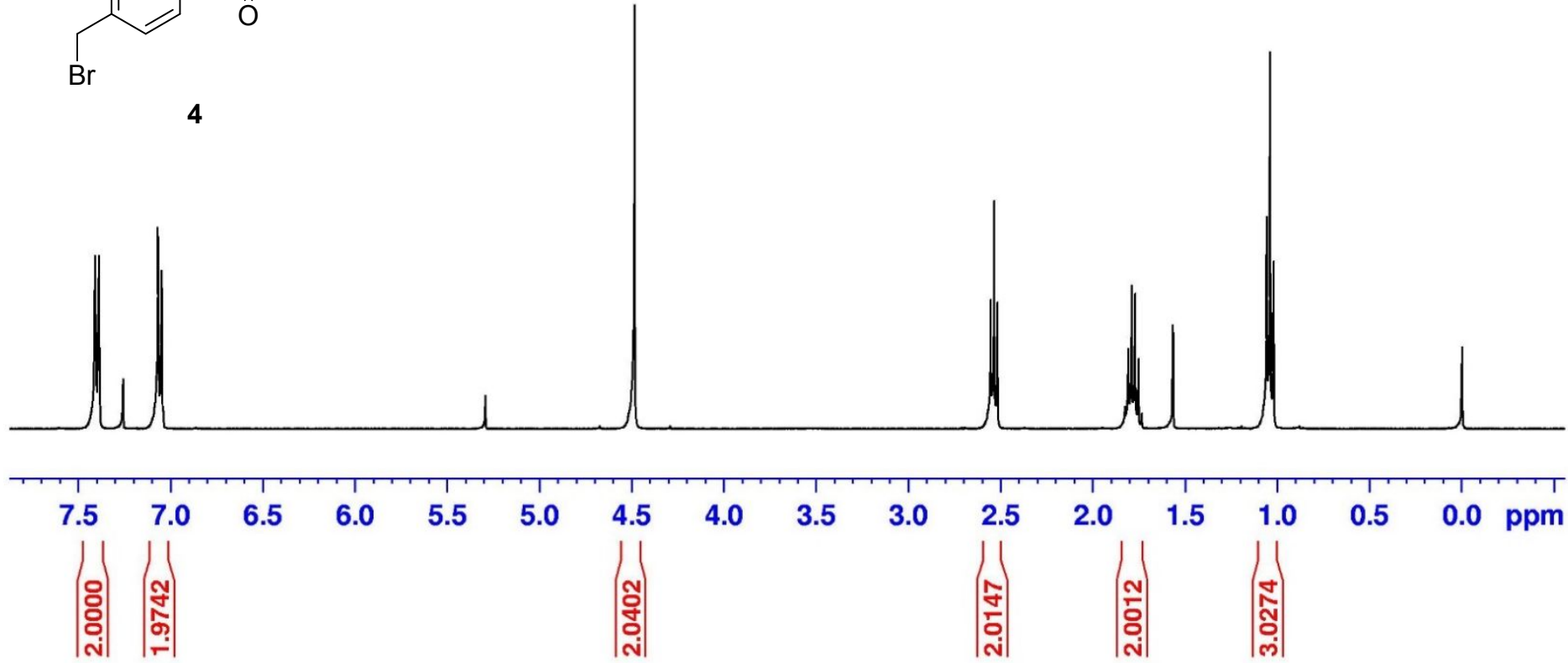

${ }^{13} \mathrm{C}-\mathrm{NMR}$ spectrum of compound 4 in $\mathrm{CDCl}_{3}(100 \mathrm{MHz})$ :<smiles>CCCC(=O)Oc1ccc(CBr)cc1</smiles>

4
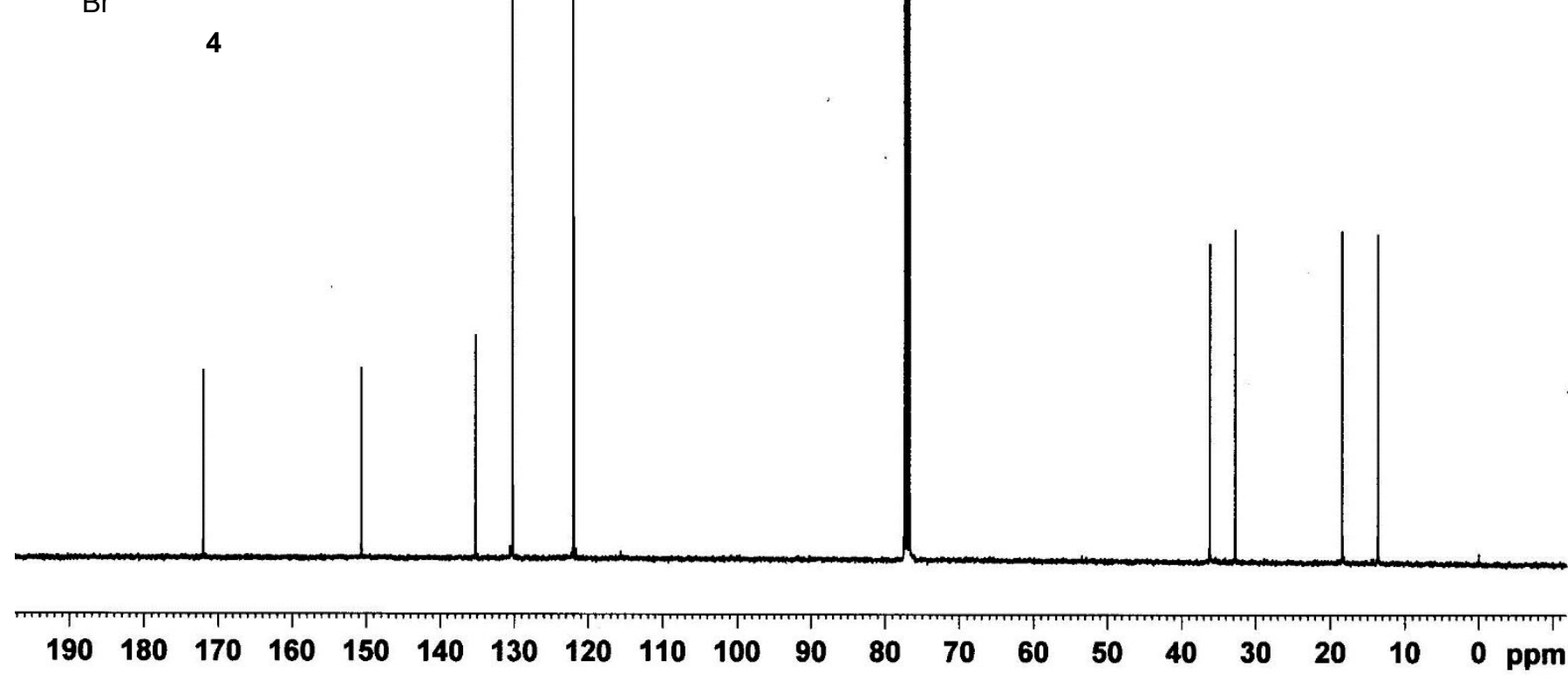
${ }^{1} \mathrm{H}-\mathrm{NMR}$ spectrum of B-MC4 in $\mathrm{CDCl}_{3}(400 \mathrm{MHz})$ :<smiles>CCCC(=O)Oc1ccc(COC(=O)C2=C3c4c(C)cc(C)n4[B-](F)(F)n4c(C)cc(C)c4N3C2)cc1</smiles>

B-MC4
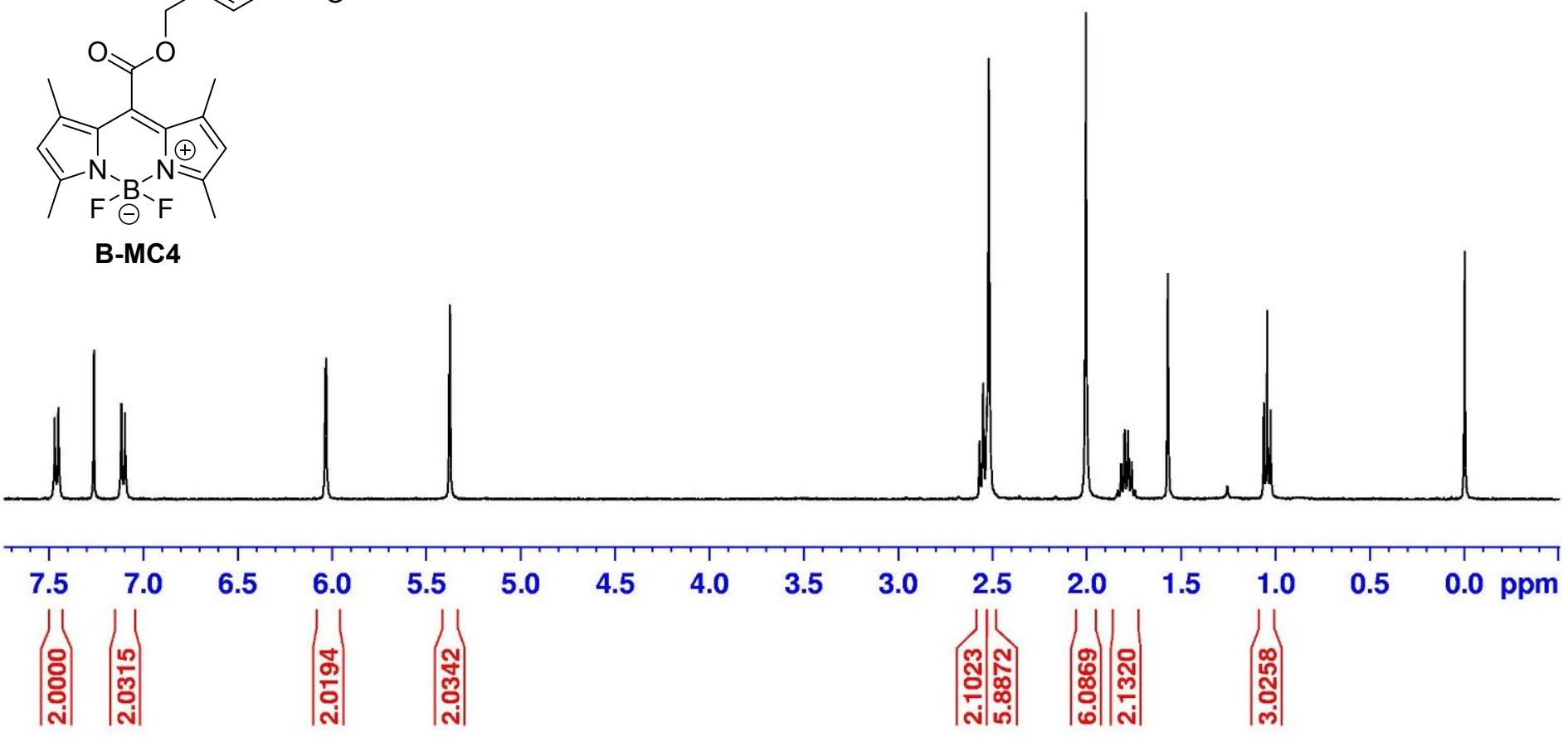

${ }^{13} \mathrm{C}$-NMR spectrum of $\mathbf{B}-\mathbf{M C} 4$ in $\mathrm{CDCl}_{3}(100 \mathrm{MHz})$ :

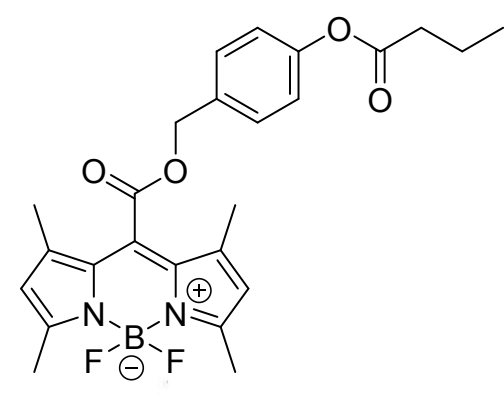

B-MC4

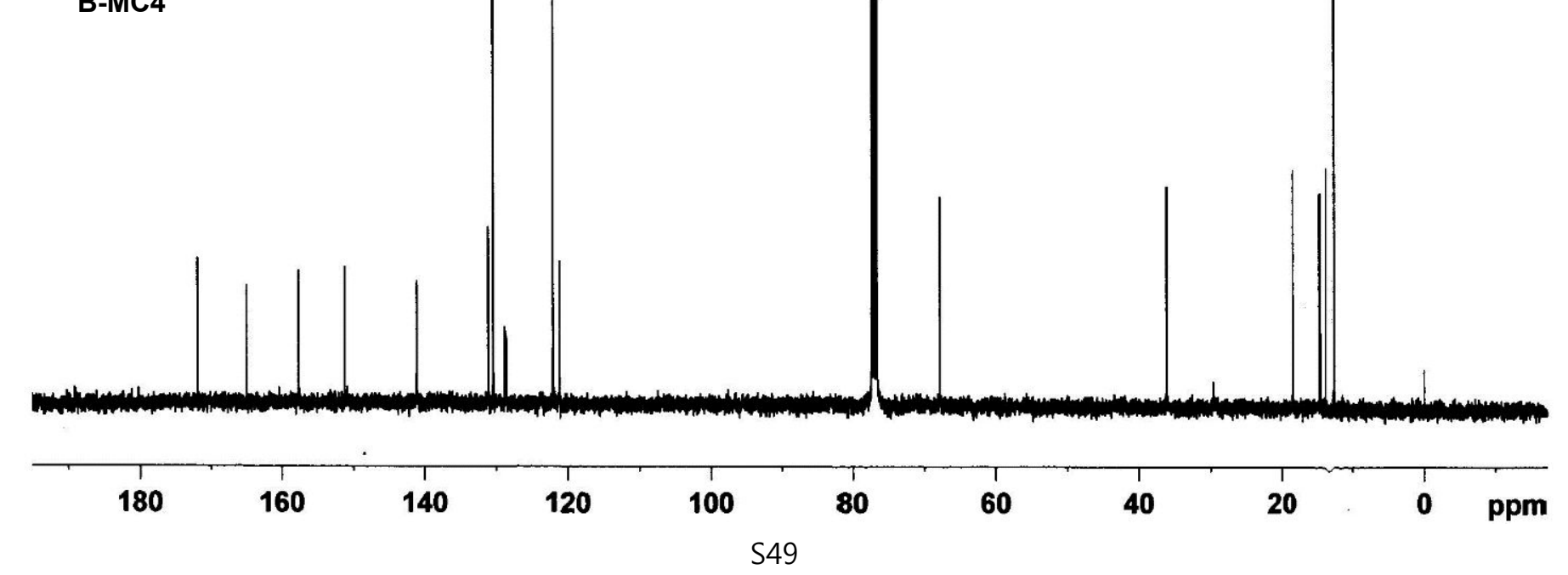


${ }^{1} \mathrm{H}-\mathrm{NMR}$ spectrum of 4-MUB in $\mathrm{CDCl}_{3}(500 \mathrm{MHz})$ :<smiles>CCCC(=O)Oc1ccc2c(C)cc(=O)oc2c1</smiles>

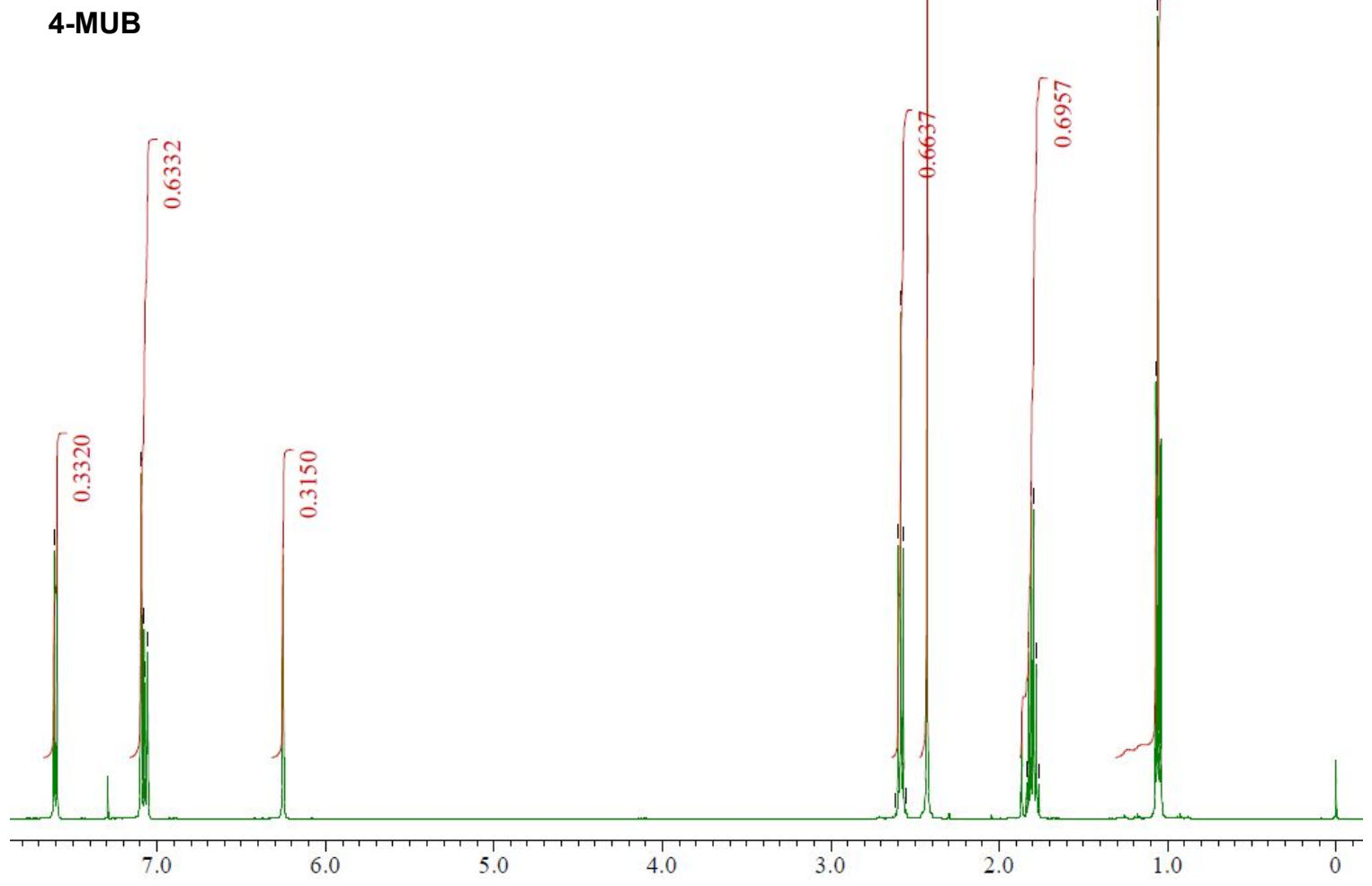

${ }^{13} \mathrm{C}-\mathrm{NMR}$ spectrum of 4-MUB in $\mathrm{CDCl}_{3}(125 \mathrm{MHz})$ :

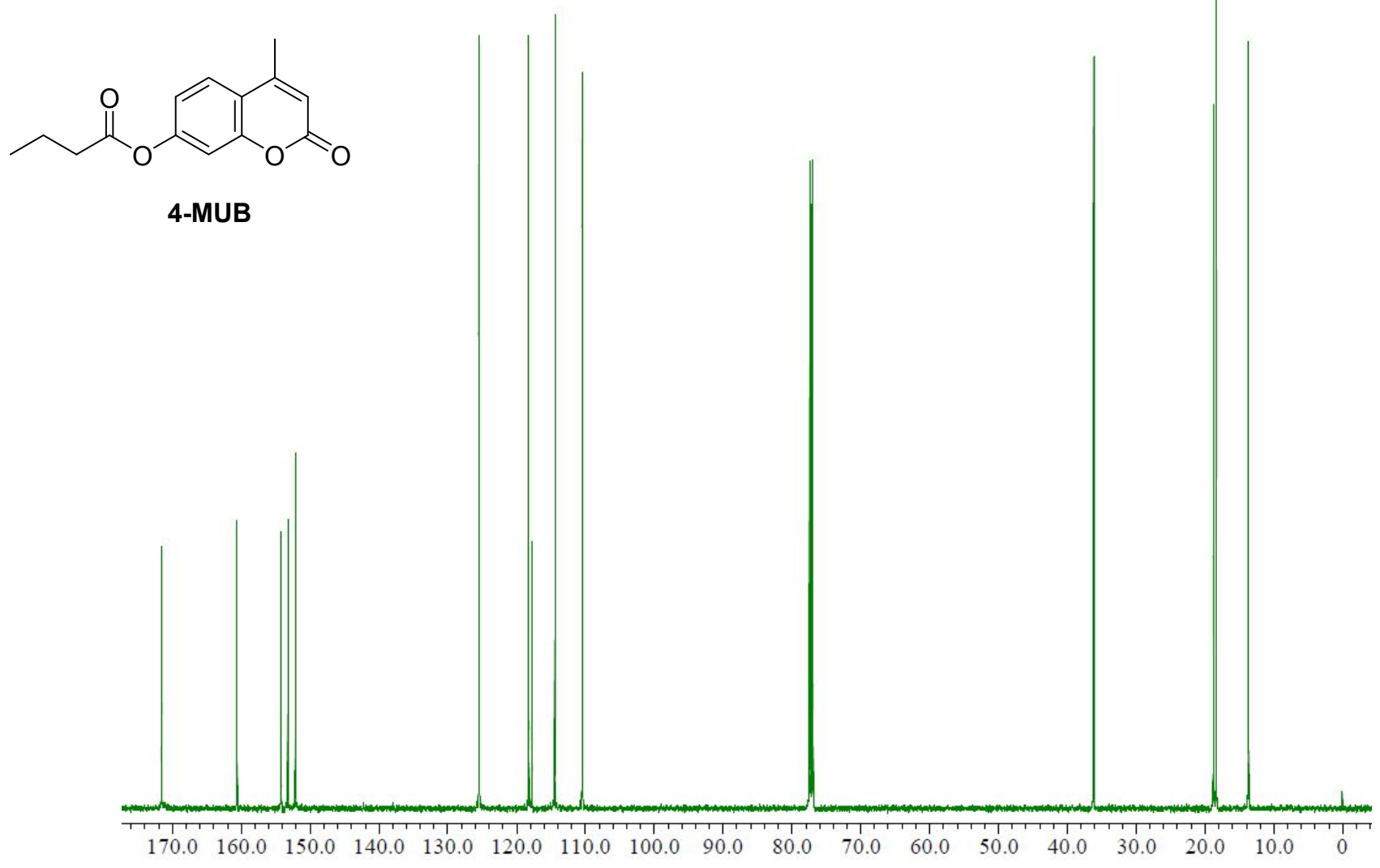




\section{References}

(1) Kim, S.; Kim, H.; Choi, Y.; Kim, Y. A New Strategy for Fluorogenic Esterase Probes Displaying Low Levels of Non-specific Hydrolysis. Chem. - Eur. J. 2015, 21, 9645-9649.

(2) a) Hakamata, W.; Tamura, S.; Hirano, T.; Nishio, T. Multicolor imaging of endoplasmic reticulum-located esterase as a prodrug activation enzyme. ACS Med. Chem. Lett. 2014, 5, 321-325; b) Jessen, H. J.; Schulz, T.; Balzarini, J.; Meier, C. Bioreversible Protection of Nucleoside Diphosphates Angew. Chem. Int. Ed. 2008, 47, 8719-8722.

(3) Ostaszewski, R.; Koszelewski, D.; Kurek, W.; Piotrowska, O. Method for detection and/or assay of lovastatin esterase with use of fluorogenic/chromogenic reagent, lovastatin esterase isolated and/or purified by this method, assembly for detection and/or assay and use of fluorogenic/chromogenic reagent for detection and/or assay of lovastatin esterase. 2009, Patent WO2009067031.

(4) Komatsu, T.; Urano, Y.; Fujikawa, Y.; Kobayashi, T.; Kojima, H.; Terai, T.; Hanaoka, K.; Nagano, T. Development of 2,6-carboxy-substituted boron dipyrromethene (BODIPY) as a novel scaffold of ratiometric fluorescent probes for live cell imaging. Chem. Commun. 2009, 7015-7017.

(5) Wei, X.-L.; Han, R.; Hu, X.; Quan, L.-H.; Liu, C.-Y.; Chang, Q.; Liao, Y.-H. Stabilization of zeylenone in rat plasma by the presence of esterase inhibitors and its LC-MS/MS assay for pharmacokietic study. Biomed. Chromatogr. 2013, 27, 636-640. 